\title{
Harvest and conservation of sooty shearwaters (Puffinus griseus) in the Marlborough Sounds, New
}

\section{Zealand}

\author{
By Amelia Frances Geary
}

\author{
A thesis submitted to \\ Victoria University of Wellington \\ in partial fulfilment of the requirements for the degree of \\ Master of Science in Conservation Biology
}

Victoria University of Wellington Te Whare Wānanga o te Ūpoko o te Ika a Māui 


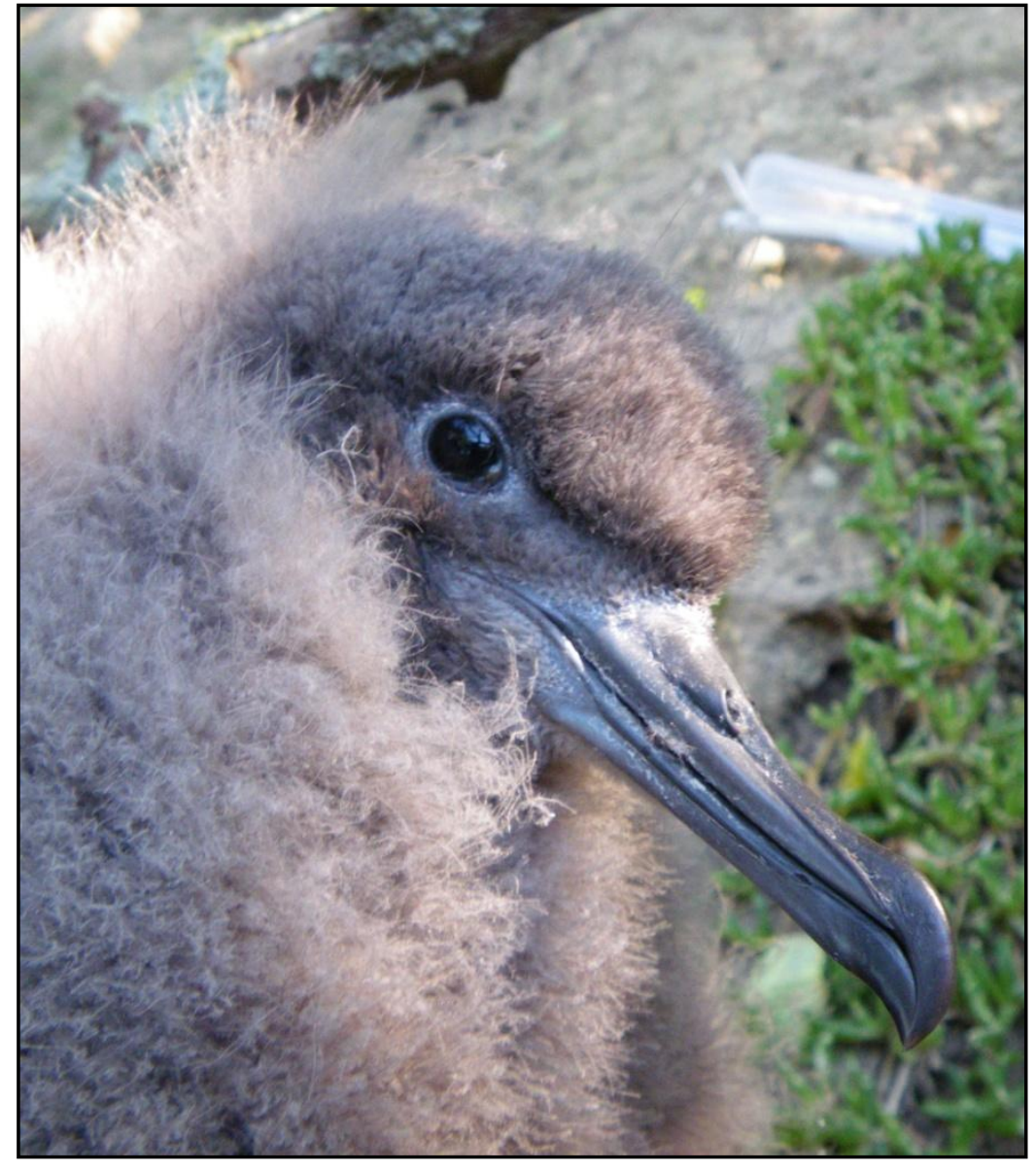

"Anything that will restore our memories is vital for the continuance of our culture." Waihaere Mason, Titīrangi, April 2009. 


\section{Abstract}

Customary harvest of wildlife can be an important mechanism through which indigenous people maintain a connection with their environment. Observations built up during harvesting events are also a useful way of monitoring change over time. However, not all traditional societies have lived harmoniously with their environment. Wildlife populations can become depleted quickly if not managed sustainably. Using traditional knowledge interviews, empirical data from two island populations and population modelling, I examined the viability of two island sooty shearwater populations in the Marlborough Sounds and their resilience to resumed, low-level harvest. The biology of the sooty shearwater populations was found to closely resemble that of populations found at higher latitudes. Historic harvest by Marlborough Māori probably had an important influence on the size of present day Marlborough populations. Viability models demonstrated that these populations were experiencing very low or negative intrinsic rates of increase. Population sizes have likely been affected by previous harvest and are not at carrying capacity. The populations are therefore vulnerable to demographic stochasticity, environmental variability and extrinsic factors such as fisheries bycatch. The low and negative growth rates for populations at small sizes not at carrying capacity are of concern where harvesting is proposed. This study provides a basis for ongoing research into the population trajectories of each island population. Harvesting is possible in one population provided an appropriate monitoring regime is established prior to harvest being undertaken, to ensure the long-term viability of Marlborough Sounds' sooty shearwater populations. 


\section{Acknowledgements}

Ka tangi te tītī, ka tangi te kākā, ka tangi hoki ko au, tihei mauri ora.

Completing this thesis has been an incredible experience and has given me a greater appreciation of the fine balance we have with our environment. Its completion would not have been possible without the assistance of my fiancé Steve Corin for not only helping in the field, but for teaching me how to use Excel, SPSS and Arc GIS, for editing my drafts, for putting up with my stress and for being there when I needed someone to bounce ideas off or to get me out the door when I was late for my bus! I am also extremely grateful to Nicky Nelson and Kristina Ramstad whose long standing relationship with members of Te Atiawa helped make this project happen. Thanks to Glenice Paine, the Motungārara Island Trustees, Ngā Takiwā o Te Atiawa whānau and those from Te Atiawa who agreed to be interviewed. I would also like to acknowledge the assistance of Raymond Smith and give thanks to the Ngāti Kuia kaumātua who gave their time to be interviewed and to those that attended the wānanga and made me feel welcome at Titīrangi. Ngā mihi maioha ki a koutou katoa.

The staff at Nelson/Marlborough Conservancy and Sounds Area Office provided invaluable advice and assistance during the course of this thesis. I would specifically like to thank Pete Gaze and Bill Cash for their support and assistance from day one. Thanks also to Shannel Courtney for answering my long list of plant identification questions. I would like to express my sincere gratitude to the rec boys at Sounds Area who often went out of their way to get me on and off the islands, a special thanks in particular to Gary Twose whose supply of biscuits on the boat ride home were welcome after long weeks in the field!

My research could not have been done without the unwavering enthusiasm of the people that helped me in the field: Peter Martin, Briar Smith, Fiona Hodge, Steve Corin, Frank Pega, Dawson Dunning, Ilse Corkery and Lorraine Cook. Additional thanks are owed to Dawson for his help with the interviews. Thanks to Mike Bell and his family 
and to Georgie Hedley and Sue Waugh for their insights into seabird research. I would like to thank Lynne and Gordon Neilson at Tombstone Backpackers in Picton for picking me up at all hours of the day and providing a warm and friendly alternative to our water tank accommodation on Long Island.

Rod Hitchmough, Graeme Taylor, Henrik Moller, Jamie Newman and Chris Jones all gave me advice, ideas, references and support during the course of this thesis. Thank you. Thanks also to Murray Williams for keeping his door open and always having time for a chat.

This project and I were funded entirely through my Foundation for Research, Science and Technology Te Tipu Pūtaiao Fellowship VUWX0801. Permission was obtained from the Victoria University of Wellington Human and Animal Ethics Committees (2008R15) and the Department of Conservation (permits: NM-25084 and NM-225556-RES). I would like to thank the staff and students from the School of Biological Sciences for their support, even a fleeting comment in the tearoom can make a big difference. Last but not least, I would like to thank my family for their support and understanding and for their enthusiasm for my work.

Iti rearea, teitei kahikatea, ka taea - Even the top of the tallest tree can be reached by the smallest bird.

Mauri ora. 


\section{Table of Contents}

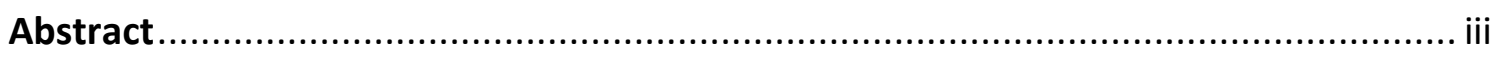

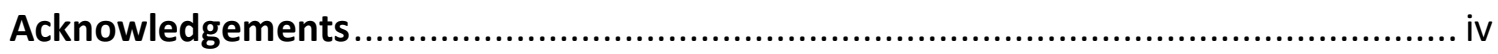

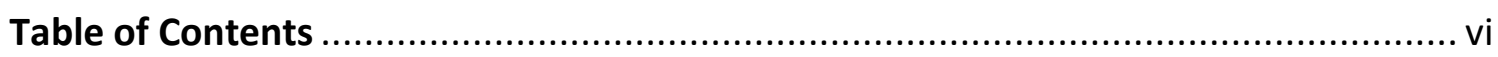

CHAPTER ONE: Sustainable harvest, traditional knowledge and population modelling: the value of a diverse approach for wildlife management .................................... 1

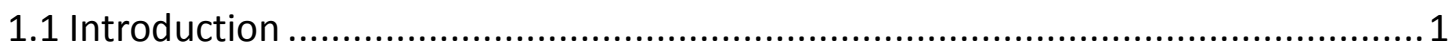

1.2 Sustainable wildlife harvest ................................................................. 2

1.2.1 Harvest strategies and traditional knowledge ....................................... 3

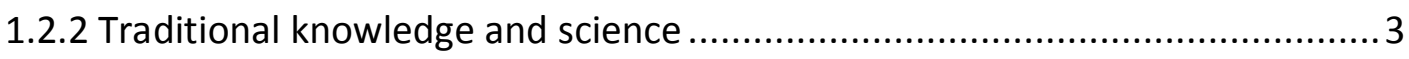

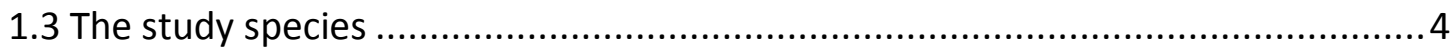

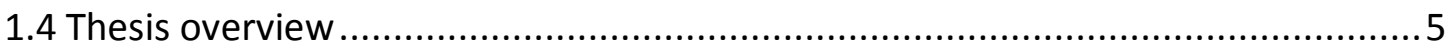

CHAPTER TWO: Muttonbirds and mātauranga: traditional harvest and conservation of sooty shearwaters (Puffinus griseus) in the Marlborough Sounds....................... 7

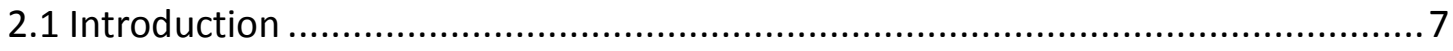

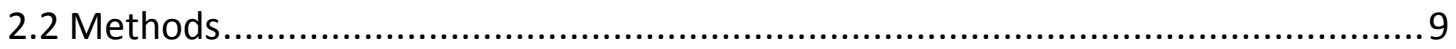

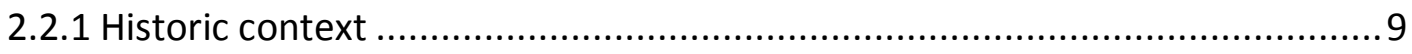

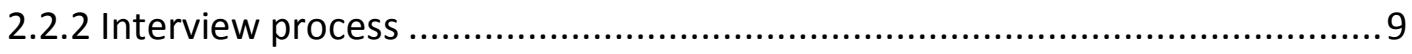

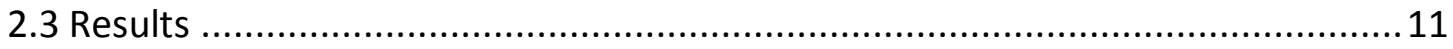

2.3.1 Sooty shearwater biology and ecology ................................................ 12

2.3.2 Muttonbirding on Motungārara and Tîtī Islands ..................................... 12

2.3.3 Tikanga and conservation management strategies ................................ 14

2.3.4 Knowledge transmission and the importance of harvest .......................... 17

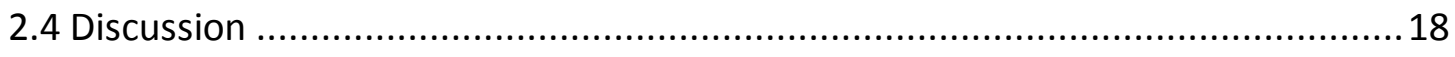

2.4.1 Sooty shearwater biology and ecology ................................................ 18

2.4.2 Muttonbirding on Motungārara and Titī Islands .....................................19

2.4.3 Conservation management strategies ................................................. 21

2.4.4 Knowledge transmission and the importance of harvest ..........................23

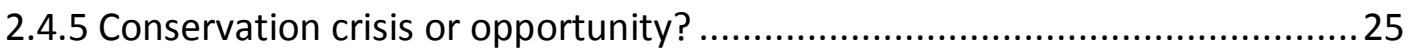


2.4.6 Conclusion

CHAPTER THREE: Biological parameters of the sooty shearwater (Puffinus griseus) on

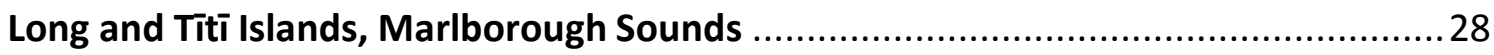

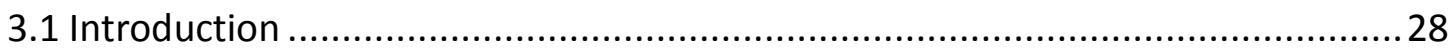

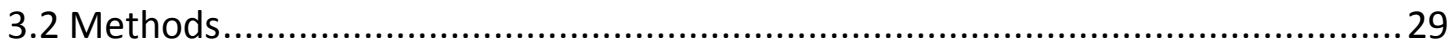

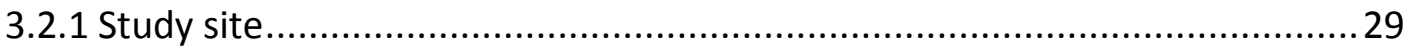

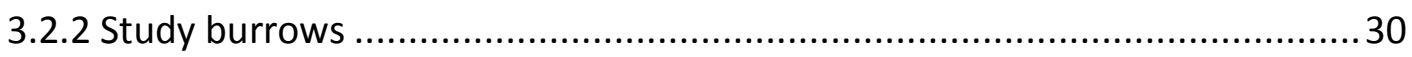

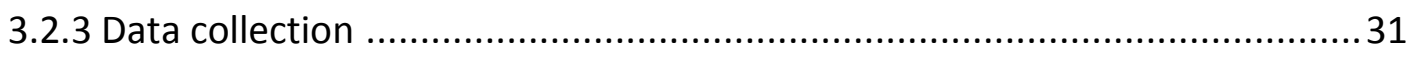

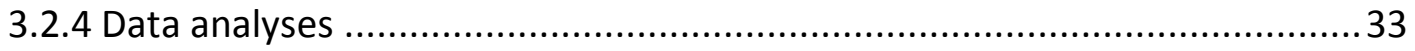

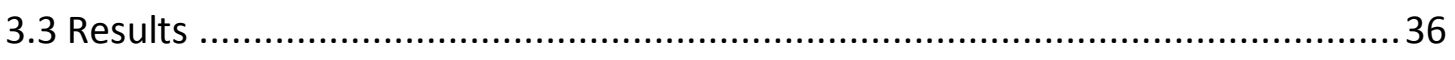

3.3.1 Burrow length and density, egg laying, hatching and fledging.....................36

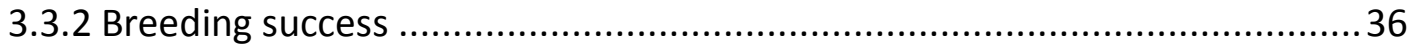

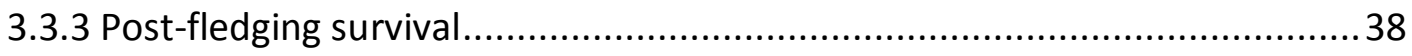

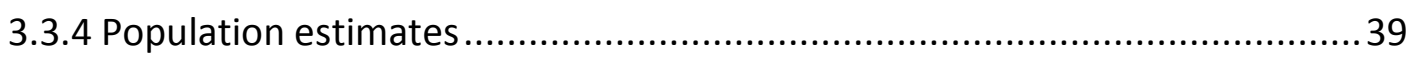

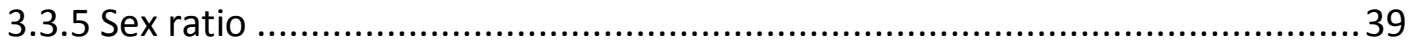

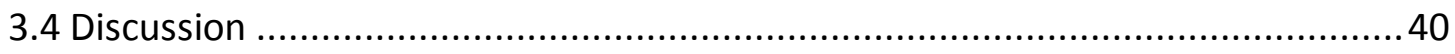

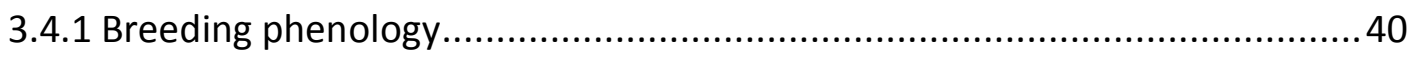

3.4.2 Breeding success and post-fledging survival ...................................... 42

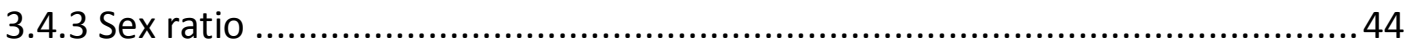

3.4.4 Population estimate .................................................................... 44

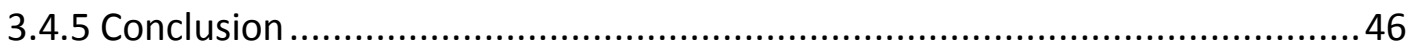

CHAPTER FOUR: The viability of two small sooty shearwater (Puffinus griseus) populations and their resilience to customary harvest ...................................... 48

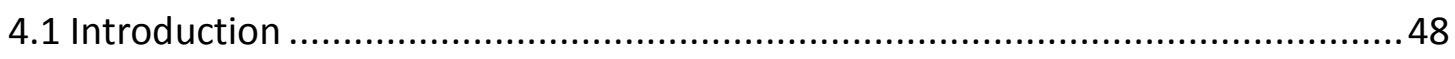

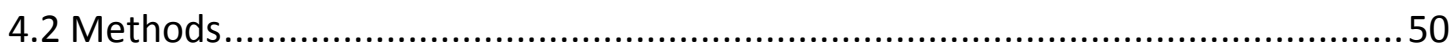

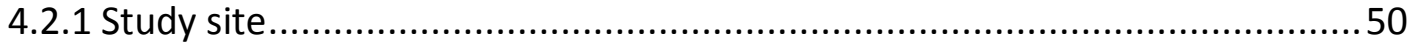

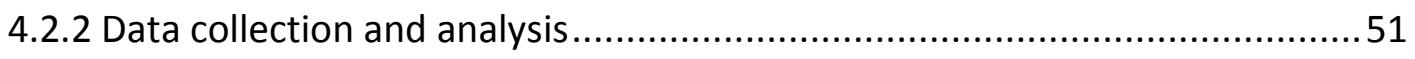

4.2.3 Biological parameters for VORTEX ............................................... 51

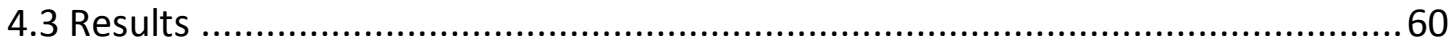

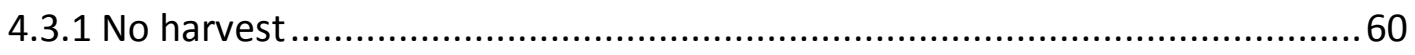

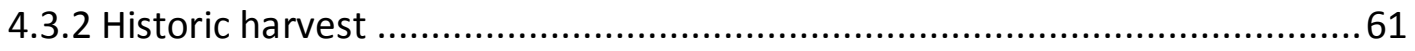




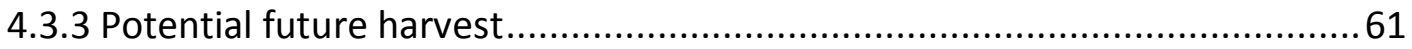

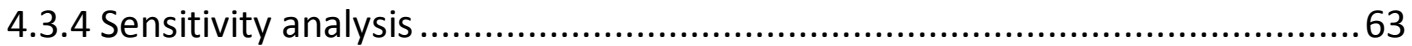

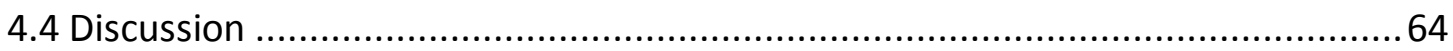

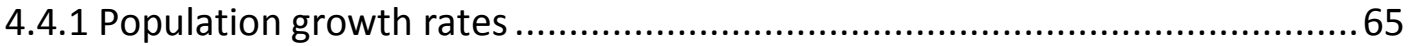

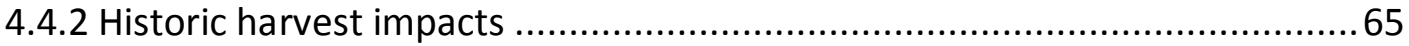

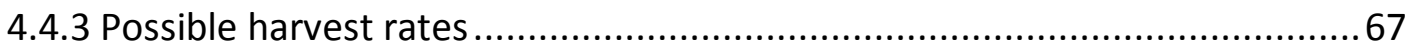

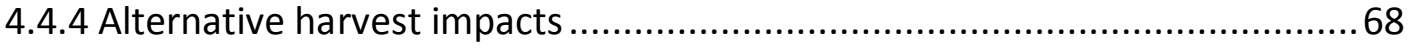

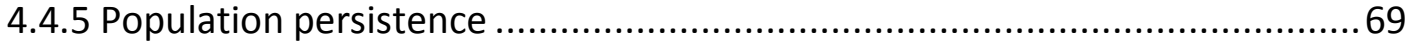

4.4.6 Uncertainty and model interpretation ........................................... 72

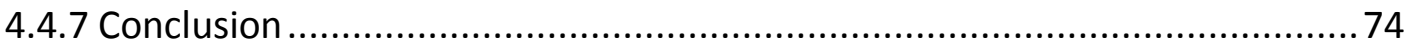

CHAPTER FIVE: A framework for harvest decision making: thesis summary and

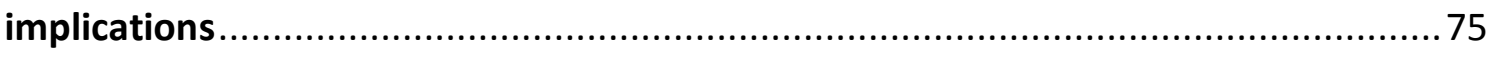

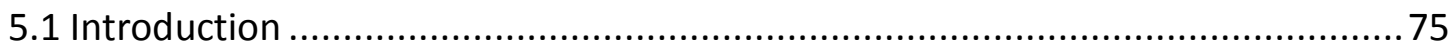

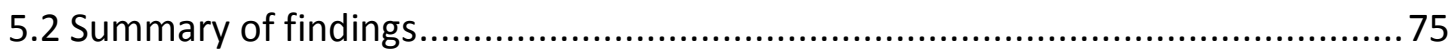

5.3 A framework for wildlife harvest decision making ...................................... 76

5.3.1 The importance of communication and consultation ................................ 77

5.3.2 Evaluation of population size .................................................... 77

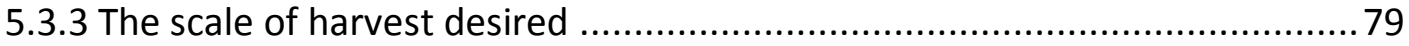

5.3.4 Determining harvest sustainability ................................................ 80

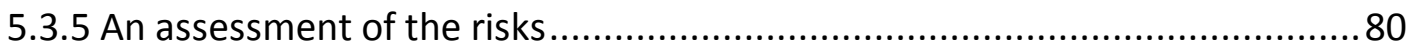

5.3.6 Can harvest impacts be mitigated? ...................................................... 81

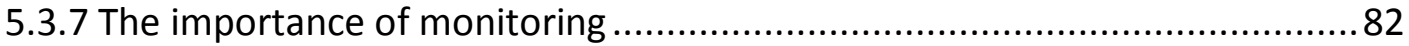

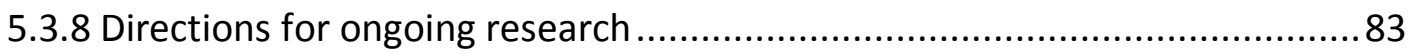

5.4 Re-establishing a connection through harvest ............................................ 83

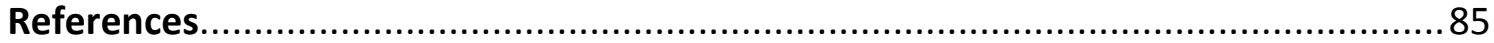




\section{Sustainable harvest, traditional knowledge and population modelling: the value of a diverse approach for wildlife management}

\subsection{Introduction}

The spread of humans across the globe came with devastating consequences to Earth's animals. For example, approximately $20 \%$ of the world's bird species were lost with the spread of humans across the Pacific (Steadman 1995). Collapsing populations of large vertebrates (Martin \& Steadman 1999) would have put great pressure on human populations to modify their behaviour. Traditional systems of management enforced through the use of taboo emerged as a form of resource management (Colding \& Folke 2001). Throughout Oceania, fishing rights were controlled by people of authority who regulated the level of exploitation within their reef or lagoon area. This approach helped conserve fish stocks and maintain an ongoing resource for the people (Johannes 1978). However, despite best attempts, our efforts at managing resources are far from totally successful. Today unsustainable harvest contributes to nearly one-third of all bird and mammal species that are threatened with extinction (Rosser \& Mainka 2002). A priority of conservation therefore must be to develop frameworks for determining the sustainability of harvest.

The harvest of wildlife remains a contentious issue. Ludwig et al. (1993) note that achieving a consensus regarding the sustainability of a harvest is difficult and is often debated even after the collapse of the resource. The authors further suggest that it is impossible to know the sustainable harvest limit of any renewable resource without first exceeding that limit. The almost complete elimination of the Atlantic cod (Gadus morhua) through overharvest (Hutchings \& Myers 1994) is a sobering reminder of this. 
Nonetheless, large scale wildlife harvests can be sustainable. Short-tailed shearwaters (Puffinus tenuirostris) off Tasmania have been harvested for decades with few detected impacts (Skira \& Wapstra 1980; Skira et al. 1986).

\subsection{Sustainable wildlife harvest}

Sustainable wildlife harvest is based on the premise that each year there is a 'doomed surplus' of juveniles that would not survive and recruit into the population (Bartmann et al. 1992). While the harvest of such a surplus would have little to no impact on the population, determining the magnitude of the reproductive surplus is a major challenge (Hilborn et al. 1995). In the case of the terecay (a river turtle; Podocnemis unifilis), overharvest of eggs and adult females by villagers along the Aguarico River, Ecuador caused dramatic declines in local populations. Researchers found that terecay nests below the river's flood line were at a higher risk of natural destruction. Harvesting from this 'doomed surplus' of eggs was found to adequately meet the consumption needs of the villagers and provided encouraging prospects for the persistence of the species (Caputo et al. 2005).

Harvesting wildlife becomes more problematic the smaller a population becomes. Once a population is small and isolated it is much more vulnerable to random events such as demographic, environmental and genetic stochasticity and the occurrence of catastrophes (Shaffer 1981). A threshold harvesting strategy, where a population is harvested to a certain level, below which no further harvest is allowed (Lande et al. 1995; Lande et al. 1997) may be useful for determining harvest strategies for small populations. However, the appropriate threshold may not be applicable to all species (for example see Tufto et al. 1999). Small populations may therefore need an adaptive management approach to ensure harvest is sustainable long-term as has been demonstrated in the adaptive harvest of North Island robins (Petroica longipes) for translocation (Dimond \& Armstrong 2007). 


\subsubsection{Harvest strategies and traditional knowledge}

Development of sustainable harvest practices is critical to the persistence of the resource. Harvest methodologies of indigenous communities are guided by their traditional knowledge which is based on their observations, experiences and adaptive techniques passed on through generations (Berkes 2008). These methods do not necessarily limit the quantity harvested; instead they guide the harvesters through mechanisms of a cultural or spiritual nature (Berkes et al. 2000; Colding \& Folke 2001; Kitson 2002). For example, the Denésotiné of the Canadian arctic have extensive traditional knowledge of caribou (Rangifer tarandus) which they have used for generations to successfully manage their annual caribou harvest (Parlee et al. 2005). Yet despite successes, traditional knowledge does not always manage harvest sustainably, for example, some traditional fishing methods in Tonga involve the destruction of parts of the coral reef to access the fish (Johannes 2003).

\subsubsection{Traditional knowledge and science}

In contrast to traditional ecological knowledge, a modern scientific approach uses quantitative data generally gathered during intensive short term field surveys. Future predictions can then be made by using a population modelling approach. The accuracy of modelling reflects the quality of the input data (Brook et al. 2000). This is concerning because in many cases, there are simply no data available, and their procurement may take a lot longer than the time it takes for the species or ecosystem to become overexploited (Johannes 1998). It is here where traditional ecological knowledge can play an important role in conservation. Although often criticised for its lack of quantitative authority, indigenous communities can provide wealth of important biological information built over time that pre-dates any scientific assessment (Johannes 2003; Moller et al. 2004). This, combined with local ecological knowledge (information developed in one person's lifetime from their own interactions with the environment) can serve to assist the conservation of species and/or environments. For example, the local ecological knowledge of Canadian Inuits alerted conservation 
scientists to an alarming population decline in the common eider (Somateria mollissima sedentaria; Gilchrist et al. 2005), which would have otherwise gone unnoticed by western scientists.

It is also important to note that scientific information can complement traditional knowledge. A good example is the declines in harvest rates of sooty shearwaters (Puffinus griseus) by Rakiura Māori of southern New Zealand. The decline in numbers could not have been explained by their traditional knowledge alone because their contact with the birds is only during the breeding season (Lyver et al. 1999; Moller et al. 2004). It was only through a collaboration with scientists that it was found that these trans-equatorial migrants are exposed to numerous threats outside their period of contact with Rakiura Māori and that this was leading to the decline (Moller et al. 2004).

\subsection{The study species}

The sooty shearwater is an excellent model species for studying harvest sustainability. It is one of New Zealand's most abundant seabirds (Warham \& Wilson 1982) with a recent study estimating the total population to be 21 million individuals (Newman et al. 2009b). It is also one of the last species still traditionally harvested by Māori (a practice known as muttonbirding; Kirikiri \& Nugent 1995; Taiepa et al. 1997). Despite its large numbers, the sooty shearwater has declined in recent decades (Scofield \& Christie 2002; Moller et al. 2009a). Population declines have been reflected in the annual muttonbird harvest (Lyver et al. 1999), in observed densities in the North Pacific (Veit et al. 1996; 1997), and in a marked reduction in burrow density on some islands (Scott et al. 2008). Small sooty shearwater populations have disappeared from predator-free islands in the Hauraki Gulf in the last century (Scott et al. 2008), implying a tenuous persistence in locations distant from the centre of the species' breeding range off southern New Zealand. Further, their typically low maximum annual growth rates (Jones 2002; Hunter \& Caswell 2005) limit their ability to sustain high levels of additional mortality and recover quickly from depletion (Dillingham \& Fletcher 2008). 


\subsection{Thesis overview}

The aim of this thesis is to investigate the traditional harvest and conservation of sooty shearwaters in the Marlborough Sounds, New Zealand. The main concepts explored are the combination of traditional knowledge, biological research and population modelling to determine a sustainable harvest level. A desire to resume traditional harvest on Motungārara and Titī Islands has been expressed by members of Te Atiawa Manawhenua ki te Tau Ihu (Te Atiawa) and Ngāti Kuia respectively. The results of this thesis will therefore provide information to both the current managers of the islands, the Department of Conservation, and each Māori tribal group which will improve their current understanding of the state of each population and each population's resilience to a return to customary harvest. The primary questions that underpin this thesis are:

1) Can Māori traditional knowledge provide information for use in population viability analysis?

2) Do the sooty shearwater populations of the Marlborough Sounds display any biological differences from populations closer to the centre of the species' breeding range?

3) Are the populations in the Marlborough Sounds resilient to the resumption of low-level harvest?

In order to answer the questions presented above, it was necessary to conduct both biological and sociological research. Chapter Two of this thesis presents the results of traditional knowledge interviews conducted with members of Te Atiawa and Ngāti Kuia. Their respective ancestors have harvested sooty shearwaters for many generations on Motungārara and Titî Islands. An analysis of their interviews is presented.

Following this, Chapter Three presents data from the 2008/09 breeding season that investigated the biological parameters of the sooty shearwater populations on Long and Titî Islands. Aspects of their biology are presented in comparison with similar biological studies that were conducted on populations at higher latitudes, closer to the centre of the species' breeding range. Due to the lack of feasibility to camp long-term 
on Motungārara, data from Long Island was used for modelling the Motungārara population.

The viability of the Motungārara and Tìtī Island sooty shearwater populations and their resilience to customary harvest were investigated using the population viability analysis (PVA) programme VORTEX version 9.96. Results from Chapters Two and Three are incorporated into the PVA. The modelling results are presented in Chapter Four. This thesis is written as a series of independent manuscripts. As a result, there is some repetition in the introductions to each chapter. Chapters Two to Four include aims, methods, results and discussions framed within the specific focus of each of the underpinning questions of this thesis and their relevance discussed in a broader context. Many Māori words are utilised, their translation is given at their first appearance in each chapter.

Finally, Chapter Five provides a synthesis of the results and presents a framework for wildlife harvest decision making to help guide conservation managers and iwi (Māori tribes) when evaluating requests to harvest wildlife. A general discussion of the core findings of my research and their implications for the resumption of traditional harvest are presented within the context of the framework. The significance of harvest on the future management of the sooty shearwater populations of the Marlborough Sounds is discussed. 


\section{Muttonbirds and mātauranga: traditional harvest and conservation of sooty shearwaters (Puffinus griseus) in the Marlborough Sounds}

\subsection{Introduction}

The interaction of indigenous communities with their environment establishes a cumulative body of knowledge that is passed on through generations (Berkes 2008). This knowledge, often referred to as traditional ecological knowledge, takes a holistic approach to the explanation of ecological processes (Turner et al. 2000). Traditional knowledge has made some important contributions to conservation. For example, local ecological knowledge of Canadian Inuit informed conservation scientists of important common eider (Somateria mollissima sedentaria) wintering habitat subsequently recommended for protection (Gilchrist et al. 2005). In addition, diagnostic features used to separate two morphologically similar species of rock wallaby (Petrogale spp.) by Bininj of western Arnhem Land, Australia may help scientists with ecological research and conservation efforts in the future (Telfer \& Garde 2006) and traditional knowledge of New Zealand Māori presented previously unknown historic distributions of tuatara (Sphenodon punctatus; Ramstad et al. 2007).

The reliance of New Zealand's Māori people on native plant and wildlife harvest for survival meant they had to develop a close relationship with their environment. Prior to European arrival in New Zealand, Māori harvested a diverse range of flora and fauna, governed by extensive spiritual and cultural protocols developed over generations (Kirikiri \& Nugent 1995; Roberts et al. 1995). Harvest regimes were (and are still) based on Māori traditional knowledge, hereon referred to as mātauranga Māori. Like knowledge systems of other indigenous peoples around the world, mātauranga Māori 
is a fluid body of knowledge built over generations. However, it has been acknowledged that assimilation into European culture has led to a breakdown in its transmission (Tau 2001). There is therefore a concern that Māori are not capable of sustainably managing wildlife using their traditional techniques (Moller 1996). As a consequence, Māori largely remain on the periphery of conservation management despite recognition in legislation and attempts to involve them at the community level (Craig et al. 2000; Lyver 2005).

Sooty shearwaters (tîtī, muttonbirds, Puffinus griseus) are an abundant, medium sized seabird that were once a seasonal source of food for iwi (Māori tribes) around New Zealand (Anderson 1997). The breeding stronghold of this trans-equatorial migrant is on islands off southern New Zealand; only two percent of the national population breeds outside of that area (Newman et al. 2009b). Despite a recent estimate of over 21 million birds (Newman et al. 2009b), the species was reclassified as Near Threatened by the IUCN in 2004 due to recent population declines (Birdlife International 2008).

The traditional harvest of sooty shearwaters (a practice known as muttonbirding) occurred historically throughout the Marlborough Sounds although its origins remain unclear. Muttonbirding was prohibited in the 1960s by the Department of Lands and Survey and it is now almost 50 years since the last harvest. Local iwi have raised concerns over the loss of their muttonbirding knowledge with the passing of kaumātua (respected elders) and a desire to resume low level harvest for the purpose of wānanga (learning forums) has been expressed. However, little is known about the viability of these sooty shearwater populations or the level of harvest they can support.

Much is now known about the biology of the sooty shearwater from studies in the centre of its breeding range off southern New Zealand. In this study, I conducted interviews with local kaumātua to try and establish knowledge that is specific to the sooty shearwater in the Marlborough Sounds area. The interviews were also established as an archive for each iwi involved. The primary objectives were to (a) determine biological and population characteristics that might be useful for modelling abundance and population growth (see Chapter Three); (b) determine the nature and 
scale of historic muttonbird harvesting on Motungārara and Tìtī Islands, and specific harvest parameters that could be used in a population viability analysis (see Chapter Four); (c) describe any traditional conservation management strategies of the species; and (d) determine the knowledge transmission mechanisms and the importance of harvest in maintaining mātauranga Māori.

\subsection{Methods}

\subsubsection{Historic context}

Ngāti Kuia is an iwi that has been in the Marlborough Sounds area, primarily in Pelorus Sound/Te Hoiere, since the migration from Hawaiki (the Māori ancestral homeland) in the thirteenth century (Mitchell \& Mitchell 2004). Ngāti Kuia historically harvested seabirds on Titī Island in outer Pelorus Sound (Fig. 2.1). Te Atiawa Manawhenua ki te Tau Ihu (hereon Te Atiawa) is an iwi that moved from the North Island to Arapawa Island and Queen Charlotte Sound/Te Tōtaranui around 1829 (Mitchell \& Mitchell 2004). It is likely that the ancestors of those that settled on Arapawa Island began harvesting seabirds on Motungārara Island in Queen Charlotte Sound (Fig. 2.1) soon after arrival in the area. During the 1800s the Crown acquired many seabird islands in the region and consequently considered the former owners to have absolved their rights to harvest. It was only at the 'indulgence of the Crown' that the removal of birds was permitted until the 1950s (MacLachlan 1968). Issues around harvest management arose in the early twentieth century and Trustees were established in 1933 to manage the harvest on Titī Island (Webb 1959) and in 1949 for Motungārara Island (Greig 1949). Despite opposition from the iwi, harvest was stopped on both islands in the 1960s due to government concerns over sustainability.

\subsubsection{Interview process}

A request to undertake this research was made by members of Ngā Takiwā o Te Atiawa whānau (Ngā Takiwā), a group of families from within Te Atiawa. The research was sanctioned by the Trustees of Motungārara Island. The Trustees of Motungārara Island 
and members of Ngā Takiwā identified individuals within their whānau (families) that were the most knowledgeable on sooty shearwater harvesting and Motungārara Island (Fig. 2.1). Traditional knowledge of five individuals was recorded through semi-directed interviews: three kaumātua who harvested as young people, one kuia (female elder) who processed the birds following harvest and one pakeke (knowledgeable adult) who worked for Te Rūnanganui o Te Atiawa, a tribal authority, at a time when muttonbird harvest was debated. All interviewees were of Te Atiawa descent, with ages ranging from 50 to 85 years. The low number of those interviewed reflects the few people still alive who have knowledge and familiarity with the sooty shearwater harvest. Interview questions were developed by conservation ecologists and Ngā Takiwā representatives to ensure the collected information was relevant to both the scientific and Māori communities involved. Questions were asked about sooty shearwater harvesting, customs associated with harvest, sooty shearwater ecology and distribution, and Motungārara Island. All interviews were conducted by two interviewers with a member of Ngā Takiwā (G. Paine) present. In one instance, an interview was conducted with an additional kaumātua present; all other interviews were undertaken with interviewees individually.

As a result of this work, I was invited to record the mātauranga Māori of Ngāti Kuia during a wānanga mahinga kai (food gathering learning forum) held at Titīrangi, Pelorus Sound in April 2009 (Gaze \& Smith 2009). Three kaumātua present at the wānanga were interviewed about their knowledge of harvesting on Titī Island using the questions developed for the interviews about harvesting on Motungārara. Two of the kaumātua had direct harvesting experience, the other had knowledge passed on from his father.

Interviews were conducted between February and April 2009, each lasting between 45 and 120 minutes. Interviewees signed consent forms to protect their intellectual property rights. All interviews were recorded digitally with a Panasonic HVX200 video camera. Interviews were transcribed using the programme WavPedal version 5.05. Transcribed interviews were returned to interviewees for correction and identification 
of parts to remain confidential. Final transcripts and video records were returned to each interviewee. A compilation of the interviews regarding Motungārara Island was given to the Ngā Takiwā Trust to archive and a video recording of the wānanga and associated interviews were presented to Ngāti Kuia.

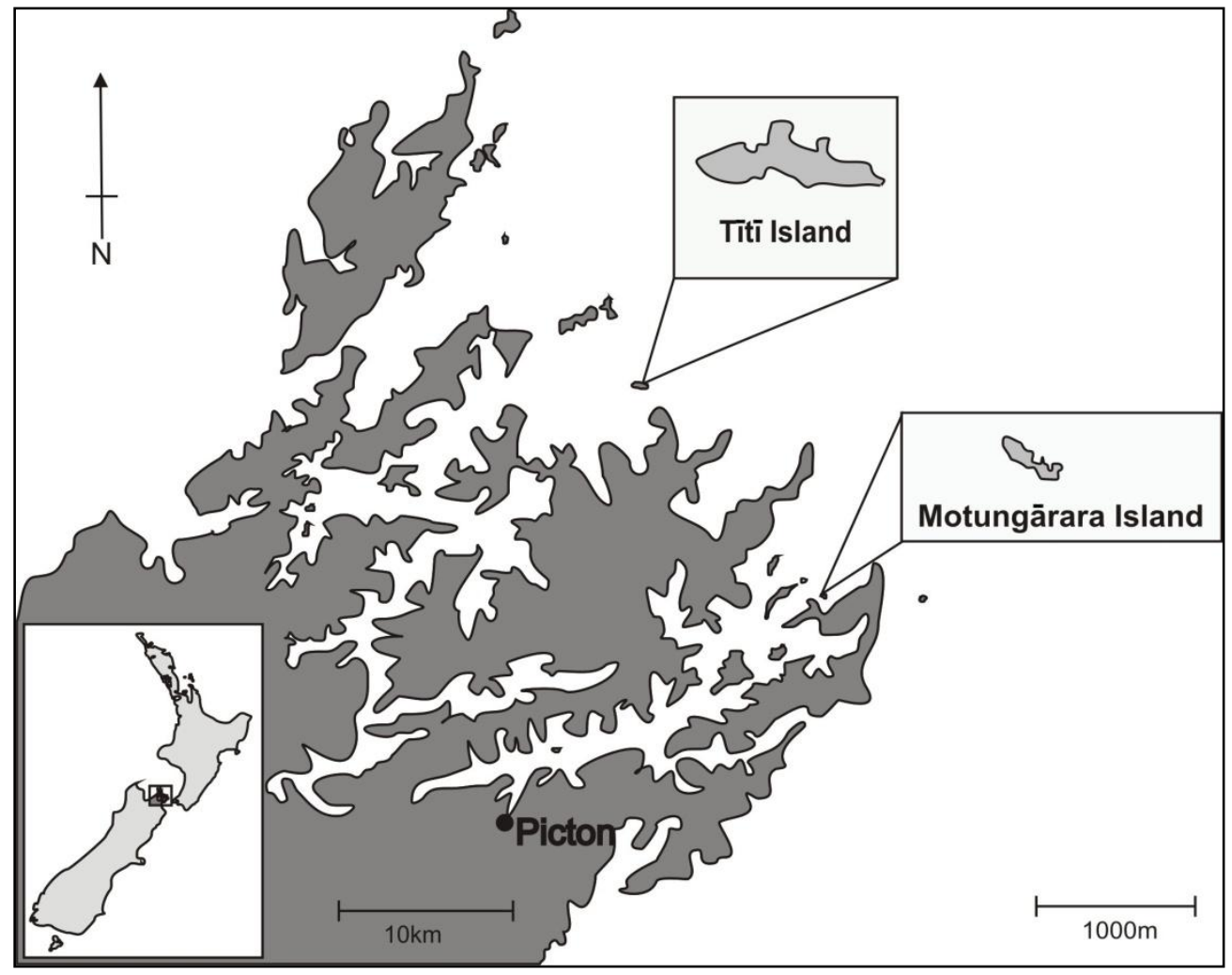

Figure 2.1: Location of islands involved in this study in the Marlborough Sounds. Titī and Motungārara are currently owned and managed by the Department of Conservation. Titî Island is a Nature Reserve. Motungārara is unoccupied Crown land. The different scales reflect the scale difference between the mainland and the islands.

\subsection{Results}

For ease of reference, all people interviewed regarding Motungārara are referred to collectively as Ngā Takiwā. Information specific to each tribal group is presented separately. Where not specified, the results given are common to both. 


\subsubsection{Sooty shearwater biology and ecology}

Only the Motungārara harvesters were asked questions about sooty shearwater ecology. All of the kaumātua identified that the birds preferred to nest in areas where the soil is friable for digging, and two kaumātua thought most burrows were found on top of Motungārara. One harvester suggested burrows were only found above the flax line that skirts the island. He described this as being the boundary, below which only little blue penguins (Eudyptula minor) were present. All kaumātua identified the birds as only producing one chick each season. Harvesters were unsure of the age of the birds when they first returned to breed or if adult birds stayed in the same pair over multiple seasons. However, two kaumātua suggested the same birds returned to the island each year to breed, one further suggested that chicks born on Motungārara come back to breed on Motungārara. One harvester knew the birds went to sea when they left the island; the others were not sure where the birds went.

Although none of the kaumātua of Motungārara could remember the number of birds once present on the island, one kaumātua suggested close to 800 pairs bred on the island during his time out harvesting. On Titī Island, none of the kaumātua could say how many birds were present in the past; two however, referred to the nearby tribal area known as Titīrangi (tītī = muttonbird; rangi = sky) which they explained meant large flocks of birds would have once filled the skies. Two kaumātua also suggested that the habitat of these birds would have also included the mainland, not just the offshore islands they are restricted to now, which would have contributed to the greater abundance of birds.

\subsubsection{Muttonbirding on Motungārara and Tìtī Islands}

On both islands, interviewees reported harvest occurring on a single day in either late March or early April, but sometimes as late as the last week of April. On Motungārara, all of the harvesters described landing on the island in the early morning while it was still dark. Early morning was considered the best time to harvest because chicks were close to the entrance of their burrows after being fed by their parent. For all harvesters 
interviewed, the primary method of extraction involved placing an arm and shoulder down the full length of the burrow. In some cases a stick was used to determine the burrow occupant. All Motungārara harvesters used the type of peck on the stick to identify the species, whereas Ngāti Kuia kaumātua used the sound or call of the bird inside. A stick was also used to coax the bird out. Two harvesters (one from each tribal group) described fraying the end of a stick, likely from flax (Phormium cookianum), and twisting it on the bird down the burrow. Shearwater chick presence was confirmed when the stick was extracted and down was attached to the end. Huge emphasis was placed on not digging out birds or damaging the burrows while on the island. It was believed that when the burrows were damaged the parents would not return to those burrows the following year. In addition, the repercussions from tribal elders for digging out a chick were apparently so severe it was avoided by all young harvesters.

All harvesters identified chicks as being the sole target while out on the islands. The majority of those asked (80\%) named the birds taken as either tītī or muttonbirds. Half of them also identified the birds as the sooty shearwater. No other target species was identified. Penguins were the only other species acknowledged to be present on the islands. Once chicks were extracted, Motungārara harvesters described crushing the skull with a thumb or biting them on the back of the head. In contrast, Titī harvesters broke the necks. Two harvesters (one from each tribal group) described placing pressure on the birds' abdomen which forced out the stomach contents. On Motungārara, the harvested birds were sometimes collected by arranging them into bunches of four, and tying their necks together with flax to be taken back to the boat. One of the harvesters described carrying up to 20 birds at a time in this manner. Chicks were processed either on the boat as the harvesters returned home, or back on the mainland. Methods for processing included dipping the chicks into boiling water to aid plucking or plucking off most of the down and singeing the rest off either in the fire (a process called hunuhunu) or with a blowlamp. Men harvested and prepared the birds while cooking was primarily undertaken by females. Women did land on Titī during a harvest but they generally fished or gathered kaimoana (seafood) and did not 
participate in the harvest itself. The birds were typically eaten fresh but, in some years, were also preserved in their own fat to help families through the winter months.

The years in which harvest was undertaken and the harvest date itself, were timed to coincide with abundant numbers of chicks in optimal condition. A harvester from both Te Atiawa and Ngāti Kuia said they never saw skinny chicks. Two Ngāti Kuia kaumātua commented that the timing was also good for other harvested species such as crayfish (Jasus edwardsii), groper (Polyprion oxygeneios), kererū (Hemiphaga novaeseelandiae) and weka (Gallirallus australis). Criteria for determining peak condition were lack of adult feathers and high fat content. Small or undersized birds were returned to their burrows, however it was not specified whether fully feathered chicks were also returned. One harvester on Motungārara described pulling a bird from a burrow and if it was not bigger or of equal size to the one before, it was put back. This was reiterated by the kuia from Ngā Takiwā who described the birds as all being large and uniform in size, comparable to the size of a bantam chicken. Harvesters from both tribal groups also commented that the advantage of harvesting downy chicks meant plucking was easier.

On Motungārara, only one harvest was undertaken in a year and the harvest was always shared between families, even with those that had not participated in the harvest that year. Between 30-80 birds were taken and shared between three to four families. Titī Island has a much larger sooty shearwater population than Motungārara. Family groups harvested on different days to minimise disturbance. One kaumātua suggested an average of twelve birds were harvested per family. The averages suggested equated to approximately 140-240 birds shared with up to twelve families. Another harvester suggested as many as 500 birds could have been poached in any one season following the closure of the island.

\subsubsection{Tikanga and conservation management strategies}

One kaumātua described the harvest as a "responsibility" (N. Watson). Eighty four percent of the kaumātua interviewed regarded harvest and respect for the 
environment while out harvesting as the key method for managing the sooty shearwater populations and their island habitat. Harvest was guided by a number of protection strategies (Table 2.1). As one kaumātua put it: “...[the harvesters] used to look after the [island] so next season the next whānau might be able to get there and there would be no damage and management would be right. Take the right ones and don't destroy the holes, that was the main thing" (G. Aldridge).

Table 2.1: Harvest and protection strategies used by Ngā Takiwā and Ngāti Kuia to manage the island shearwater populations.

\begin{tabular}{|c|c|}
\hline Concept & Strategy \\
\hline \multirow[t]{6}{*}{$\begin{array}{l}\text { Regulation of } \\
\text { numbers harvested }\end{array}$} & $\begin{array}{l}\text { Number of chicks harvested adjusted seasonally depending on the } \\
\text { number of chicks available. }\end{array}$ \\
\hline & $\begin{array}{l}\text { Only chicks harvested, never adults, to ensure the long-term } \\
\text { persistence of the population. }\end{array}$ \\
\hline & Regulation through only harvesting every second chick. \\
\hline & $\begin{array}{l}\text { Harvested chicks of uniform size, equal to or bigger than the chick } \\
\text { harvested earlier. }\end{array}$ \\
\hline & All small or undersized chicks returned to their burrow. \\
\hline & $\begin{array}{l}\text { Harvest conducted over one day although Ngāti Kuia spread } \\
\text { harvest out over a number of days, one day per whānau or group } \\
\text { of whānau. }\end{array}$ \\
\hline \multirow[t]{4}{*}{ Protection of habitat } & $\begin{array}{l}\text { Movement within colonies adjusted to minimise damage, all } \\
\text { damaged burrows restored as best possible. }\end{array}$ \\
\hline & No digging of burrows to access chicks. \\
\hline & No damage or modification to the bird's habitat undertaken, Ngāti \\
\hline & $\begin{array}{l}\text { Kuia did allow minimal clearing of undergrowth to enable easier } \\
\text { access to burrows by returning adult birds. }\end{array}$ \\
\hline \multirow[t]{2}{*}{ Control of access } & $\begin{array}{l}\text { Rights to harvest were restricted to those whānau with ancestral } \\
\text { ties to the islands. }\end{array}$ \\
\hline & $\begin{array}{l}\text { There was never any settlement or long-term occupation of the } \\
\text { islands. Occasionally some slept overnight but left soon } \\
\text { thereafter. }\end{array}$ \\
\hline
\end{tabular}


The number of birds harvested fluctuated annually. One Motungārara harvester commented that the number of chicks available could fluctuate dramatically between years. He remembered occasionally harvesting barely enough for a meal but the following trip there being an abundance of chicks. Sixty percent of the harvesters stated that the size of the take reflected the number of birds available. Poor seasons were attributed to the parent birds either fishing too far out at sea to feed the chicks regularly or to parents having abandoned the chicks too early. According to all three Motungārara harvesters, harvester experience was required to make a good judgement as to the number of sooty shearwaters to take. The Trustees charged with managing the harvests determined years in which the harvest would take place. According to the Ngā Takiwā kuia, two short trips were made to Motungārara in December and again in February to check on the state of the population, the result determined whether harvest would take place that year. A similar process also occurred on Titī Island.

Concern was expressed that iwi have little involvement with the management of the islands and the birds. The apparent decline or reduction in bird numbers was cited as a reason why harvest was stopped, yet one kaumātua from each tribal group suggested that populations were declining because iwi were not out harvesting. Harvesting was ceased by the Department of Lands and Survey in 1960 on Titī (Gaze 2000) and 1963 on Motungārara (Douglas 1963); an interviewee from each tribal group identified poaching as an issue at the time and since harvest cessation. Another kaumātua expressed the classic dichotomy between the Western conservationists who oversaw the island and the local Māori who still wanted to manage it their way: "The reason why we stopped [harvesting]...government took over, conservationists came in but we were already [conserving the population], by harvesting every second bird, so the birdlife kept going" (J. Aldridge).

Almost all of the interviewees (88\%) expressed a desire to see low level harvest allowed on the islands. The majority (75\%) wanted to see harvest resume for teaching and knowledge recording purposes only, to pass on the knowledge and tradition to the 
younger generation. One Motungārara harvester stated: "I would like to take my mokopuna [grandchildren] there; I would like them to be able to take [muttonbirds] but they need to learn the right way, what and how to do it, to understand that it's not only an important food resource, that if it's not cared for in the manner...of good [kaitiakitanga] (guardianship)...[the birds] could be lost" (N. Watson).

\subsubsection{Knowledge transmission and the importance of harvest}

The right to harvest on Motungārara and Titī Islands was determined through whakapapa (bloodline, hereditary right) to Te Atiawa families of Arapawa Island and Ngāti Kuia respectively. Thirty three percent of kaumātua interviewed from each iwi suggested harvesting began on the islands close to the time the respective tribal groups established in the Marlborough Sounds area. The remaining two thirds knew harvesting began many generations before but could not be certain of exactly when.

The majority of harvesters (80\%) first went out as young boys (mean age 10; range 7 14). All of them learnt the skills of harvest from older relatives, primarily fathers, uncles and grandfathers, while out on the island. All interviewees identified tītī or muttonbirds as a culturally significant supplementary food gathered primarily for family consumption and for hui (gatherings). The process of harvesting, preparing and eating the birds could take several days and was important for maintaining strong familial relationships. This was identified by one harvester as an important time for the telling of stories and the sharing of knowledge. During the wānanga at Titìrangi one kaumātua explained: "It's important to include...your rangatahi (young people) and your [mokopuna] in these journeys because that is the way of our people, to inculcate knowledge from the past to take forward into the future. Only by first hand experience can one do that" (W. Mason). In addition, the ability to serve up special food collected from within their tribal area was identified as a source of pride. Two harvesters also commented that they preferred the fresh birds to the salted ones obtained from Rakiura Māori off the southern islands of New Zealand. 
When asked about their knowledge of prayers and proverbs associated with their respective island and its harvest, one kaumātua from each iwi commented that very little or no Māori language was used during their youth. One kaumātua from Ngā Takiwā remembered an uncle reciting a karakia (prayer) before undertaking a harvesting trip. Another from Ngāti Kuia suggested they were used but were more generic rather than specific to the birds or the harvest itself. Only one kaumātua from Ngāti Kuia could recite whakataukī (proverbs) associated with tītī - one in Māori, one in English. The one in English was: "Where were you when the tītī cried? We were there" (R. Smith). This was explained to be particularly important to the situation on Titī Island at the present time because, as he stated "we are here to recognise that there is something wrong [with the current state of the sooty shearwater population] and hopefully [we can] be a part of some system that will possibly re-enhance or protect what's there, the best way we can" (R. Smith). No one else knew of any whakatauki associated with their respective island or the harvest.

\subsection{Discussion}

\subsubsection{Sooty shearwater biology and ecology}

Although the mātauranga Māori of sooty shearwater biology and ecology was not extensive, the knowledge that was presented did match the scientific knowledge of the species. The harvesters' level of knowledge was likely a direct reflection of the amount of contact they had with the birds. This species spends the majority of its life at sea and only comes to land to breed (Warham 1990; Shaffer et al. 2006). The only contact the kaumātua had with the birds was during the traditional harvest which took place over a day or morning once a year; therefore any specific knowledge would reflect this.

Nonetheless, annual changes in abundance and population declines were likely noticed and passed on which is important for long-term monitoring. In contrast, Māori had an intricate knowledge of the diet and biology of kiore (Rattus exulans), an important food source with which they had greater contact (Haami 1994). This sentiment is mirrored in Arctic Inuit communities where the quality of their knowledge of four migratory bird 
species directly reflected the amount of exposure they had to each species (Gilchrist et al. 2005).

Some of the mātauranga Māori may have contained errors but this is not unusual in any discipline. For example, it is unlikely that Motungārara could have ever supported the 800 pairs of sooty shearwaters suggested by one kaumātua. Motungārara does have the potentially confounding presence of karaka (Corynocarpus laevigatus), under which seabird burrows do not occur (Bell 1955a; pers obs.) and which may be slowly encroaching on seabird burrowing habitat on the island. Therefore, the population could have been larger historically but probably not as large as 800 pairs. The suggestion of such a large population occurring on Motungārara may reflect the lack of exposure required to reinforce mātauranga Māori (Nabhan 2000). Or it perhaps reflects knowledge that incorporates historical populations, not solely found on Motungārara, but that may have once occurred in different locations throughout the Marlborough Sounds. The reference to Tītīrangi and its interpretation by Ngāti Kuia kaumātua gives evidence of this. Regardless, historic population size estimates of Motungārara and Titī Islands are limited and estimation of their size is difficult.

\subsubsection{Muttonbirding on Motungārara and Tìtī Islands}

The muttonbirding process did not differ greatly between Ngā Takiwā and Ngāti Kuia harvesters. Their methods were very similar to those used to harvest oi (grey-faced petrel, Pterodroma macroptera gouldi) by Hauraki Māori on islands off the Coromandel (Lyver et al. 2008a). The short duration of the harvesting trips and restricted access to the islands outside of the harvesting period was also observed by Hauraki Māori (Lyver et al. 2008a) and Mikura Islanders off Japan who relied on the harvest of streaked shearwaters (Calonectris leucomelas) for survival (Oka 1994). Prohibited access to the Rakiura Titī Islands is observed by Rakiura Māori (Kitson \& Moller 2008) but the length of their harvest contrasts significantly with the harvesting period observed in the Marlborough Sounds. The sooty shearwater 'birding season' on the Rakiura Titī Islands is open from 1 April until 31 May and harvesters will commonly stay for several weeks 
(Wilson 1979). However, apart from occasional nights spent on the islands, long-term occupation has never been possible on Motungārara or Tîtī due to their size and topography. Motungārara and Titī Island harvesters therefore developed their own mātauranga Māori of muttonbirding specific to the conditions of their environment. Harvests were not undertaken annually but generally coincided with chick abundance, good chick condition and good years in other food sources. The periodicity of harvest may demonstrate an adaptation to the variability of the resource. The Denésotiné of northern Canada have learnt to adapt to the variability in the annual movements and abundance of caribou (Rangifer tarandus) during their migration. Denésołiné hunters and their families will travel tens to hundreds of kilometres to track the herds and harvest enough to sustain them through the winter (Parlee et al. 2005). For Motungārara and Titī Island harvesters, the seabird resource was perhaps not as vital to their survival as the caribou is to the Denésotiné so they could therefore afford to alternate years of harvest. Therefore, this strategy of alternation may in fact demonstrate optimal foraging, whereby foraging success is maximised in relation to the effort exerted to acquire the resource (Perry \& Pianka 1997). That is, birds were only taken in years that provided the most birds for the amount of effort expended. Historic harvest estimates provided important parameters with which to conduct population viability analysis (see Chapter Four) and better understand the human influence on the Motungārara and Titī Island sooty shearwater populations. Similarly, Berman and Kofinas (2004) found the integration of knowledge from two disparate sources assisted in the assessment of the effects of climate change on the subsistence harvest of caribou of a small Arctic community. One of the authors' conclusions was that the co-production of both indigenous and scientific knowledge can provide insights into common problems. This is also true of this study where the integration of Ngā Takiwā and Ngāti Kuia mātauranga Māori into a population viability analysis provided important information for the island managers as well as the iwi. 


\subsubsection{Conservation management strategies}

Mātauranga Māori revealed a number of conservation management strategies particular to the Marlborough Sounds. Harvesting according to methods passed on from the older generations was thought to be critical to the long-term management of the sooty shearwaters and their habitat. A key aspect of this was the protection of the burrows. Protection of the burrows has been acknowledged as important in other seabird harvests by Māori (Kitson \& Moller 2008; Lyver et al. 2008a; Moller et al. 2009b), but the 'no digging' rule of the Motungārara and Titī Island harvesters contrasts with other studies. For example, to access grey-faced petrel chicks (Pterodroma macroptera gouldi), some Hauraki Māori would create a hole an arm's length from the entrance of the burrow if the chick was out of reach. They would then reinsert their arm and extract the chick before using the soil from the hole to create a back wall for the front section of the burrow, effectively creating two burrows (Lyver et al. 2008a). Similarly, Rakiura Māori will dig through the burrow roof when a chick is inaccessible, but the soil is then used to plug the hole rather than building a wall (Kitson \& Moller 2008). A study of the flesh-footed shearwater (Puffinus carneipes) found that longer burrows had a higher rate of fledgling success (McClellan 1996). A similar pattern was also possible on Long and Titī Islands (Chapter Three). If shorter burrows produce fewer chicks, then the restriction by Ngā Takiwā and Ngāti Kuia harvesters to only take chicks from burrows within reach or within coaxing distance may reduce the impact of harvest on the population.

The annual adjustment of the quantity of chicks harvested may also influence the harvest's long-term sustainability. Harvesting a proportion of the population has a much lower impact than removing a fixed number of individuals (McCarthy 1996; Brook \& Whitehead 2005). This may have already been facilitated through the alternating of years in which harvest was conducted. However, knowing the number of sooty shearwaters that could be taken came with experience. This could prove problematic should harvest resume in the future because those with harvest experience are now all over 60 and were all young boys at the time of harvest cessation. It is unlikely that they 
ever developed the skills required to decide harvest quantities. Combining insights from both indigenous knowledge and western science may develop better resource management practices than the sole use of one practice over the other (Johannes 2003). Ngā Takiwā and Ngāti Kuia may need to utilise methods derived from alternative sources such as the results of this thesis, in conjunction with their own techniques, to ensure harvest is conducted at sustainable levels.

Harvesters on both Motungārara and Tîtī targeted large chicks. Several kaumātua stated they never saw underweight chicks but in the unusual event that one was removed from its burrow, it was returned. Harvest occurred when chicks were about two months old which coincides quite closely with their peak weight during development (Richdale 1963). Chicks that are underweight at fledging are unlikely to survive and contribute to the breeding population (Sagar \& Horning 1998). It has been suggested that returning the small or undersized chicks to their burrows during the early April nanao (when chicks are extracted during the day) potentially reduces Rakiura Māori harvest impacts as those chicks could still gain the weight required to fledge and later recruit into the breeding population (Kitson \& Moller 2008). A study that investigated the effects of selective harvest on sooty shearwater population growth rates found that growth rate was influenced by harvest intensity. Selection was found to have little impact on growth rates at low harvest intensities (Hunter \& Caswell 2005, but see Chapter Four). However, when populations are small, selectivity may make a critical difference to the harvest sustainability because the chicks that are not selected would be disproportionately light. This would reduce the fledging rate of the population and is an important area for further research into harvest sustainability in the Marlborough Sounds.

Whakapapa was possibly once an important way for local whānau to control access to, and the harvest process on, Motungārara and Titī Islands. This is a measure that resembles the traditional reef and lagoon tenure practices of Pacific Islanders (Johannes 1978). However, rather than allowing traditional management of the harvest, the New Zealand government regulated the harvest through the implementation of 
Trustees who were answerable to the Department of Internal Affairs. Poaching was identified as a problem, particularly on Motungārara, both at the time of harvest cessation and later. In some cases, return of a resource to tribal management has proven successful in preventing unlawful harvest. For example, the return of management and control of kiekie harvest (Freycinetia baueriana) to Ngāti Rakaipaaka by the Department of Conservation prevented potential overharvest of the resource by another iwi (Coombes 2007). In another example, Canadian government managers honoured their co-management agreement and did not intervene in the management of caribou (Rangifer tarandus) by Chisasibi Cree elders following an overharvest undertaken by young Chisasibi hunters. The Chisasibi elders reprimanded the young hunters through re-instilling an historic lesson through oral tradition. The result had profound effects on the young hunters and the following harvest was undertaken with restraint and respect (Berkes \& Turner 2006; Berkes 2008). Effective resource management may only succeed when supported and enforced by the those with access to the resource (Johannes 1978; Kitson \& Moller 2008) or when the management comes from their own cultural perspective (Berkes \& Turner 2006; Moller et al. 2009b). Therefore, if poaching is to cease, then the authority may need to come from the kaumātua or kaitiaki (guardians) of Titī and Motungārara Islands.

\subsubsection{Knowledge transmission and the importance of harvest}

The mātauranga Māori presented here is consistent with knowledge current around the time of harvest cessation. This demonstrates that the transmission mechanisms through which the knowledge was learnt must have been effective and that the mātauranga Māori of those interviewed has not diminished despite a long absence from the harvested resource. Interviews with a Trustee of Motungārara and a Ngāti Kuia woman were presented in a report on muttonbirding conducted by a Senior Field Officer of the Wildlife Division in 1955 (Bell 1955b). The Trustee indicated that only one species was harvested on Motungārara and no other shearwater species nested on the island. The Ngāti Kuia woman stated that the Titî Island Trustees were very strict about 
the harvest practices: no trees were to be cut and fires were only to be lit below the high tide mark. She also emphasised that the total harvest was divided equally among the harvesters. Interestingly, the use of fires was not specifically mentioned in the 2009 interviews, it may be that this was not seen to be relevant during the course of the interviews or it may be an indicator that the long absence from the islands is starting to have an effect. Nabhan (2000) suggested that the extirpation of (and therefore lack of contact with) green sea turtle (Chelonia mydas) populations adjacent to villages of Comcáac Indians may contribute to a demise in the Comcáac knowledge of the species. Luckily for Ngāti Kuia and Ngā Takiwā, the sooty shearwater populations persist but there may be an urgency to pass on the mātauranga Māori that remains so it does not diminish further.

The importance of allowing harvest for knowledge building was expressed by all interviewees. Half of the kaumātua interviewed also stated that sooty shearwater population monitoring was needed. All Ngāti Kuia kaumātua expressed concern at the state of the shearwater population following the paucity of available birds during the 2009 wānanga. The two kaumātua with direct harvesting experience noted significant declines since their last experiences on the island in the 1950s and 1970s. The knowledge-building process can be at risk when those with knowledge are few and the process through which knowledge is acquired and passed on breaks down (DavidsonHunt \& Berkes 2003; Berkes 2009). Shearwater monitoring on Titī Island suggests the population has not increased since the eradication of Norway rats in the 1970s (Gaze 2000). Ngāti Kuia kaumātua desire to be involved in monitoring (Gaze \& Smith 2009). This, accompanied with semi-regular harvesting wānanga, would undoubtedly increase the knowledge base of the iwi and keep them interacting with the birds and the islands. Ngā Takiwā would similarly benefit from such interactions through the exchange of harvest experience with active conservation and population monitoring to maintain their interactions with Motungārara and the sooty shearwater population that remains. The lack of knowledge of proverbs associated with the birds and the harvest may represent a loss of knowledge over time. Much ecological knowledge can be found in 
proverbs and they can be an important way of passing knowledge on (Wehi 2009). Existing proverbs encapsulate information such as the sooty shearwater's ability to sustain long periods of flight, its laying of only one egg, the timing of its arrival to its colony and feeding patterns (Mead \& Grove 2001). For example, "he manawa tītī" translates as "a muttonbird's heart" which, according to Mead and Grove (2001) is a metaphor for a person with high levels of endurance as the sooty shearwater was believed to have an exceptional continuous flying ability. It is unknown, but interesting to consider, how Māori would have come to know this, and it does corroborate with a study that tracked the sooty shearwater migration using satellite transmitters (Shaffer et al. 2006). Oral traditions, including stories, can provide insight into ecological relationships and may provide insights into rare or extinct species, for example, the hakawai of Māori mythology (Miskelly 1987). The lack of proverbs presented by Ngā Takiwā and Ngāti Kuia may reflect the limited contact associated with the harvest or it may be that proverbs were not particularly used by each tribal group. It is also possible that Māori assimilation into European culture has led to a breakdown in their retention and transmission (Tau 2001).

\subsubsection{Conservation crisis or opportunity?}

Only seventeen chicks fledged off Motungārara in 2009 (Chapter Four). Given the carrying capacity of the island of approximately 550 birds, the sooty shearwater population is arguably experiencing a crisis. Traditional knowledge regarding the exploitation of resources and the development of a conservation ethic often develops following a resource crisis (Berkes \& Turner 2006). Human impact on new, unexplored territories can be devastating, but over time, as experience and understanding develops, a level of 'symbiosis' can occur (Berkes \& Turner 2006). For example, the Aranda of central Australia forbid the hunting of red kangaroos (Macropus rufus), a culturally important animal, near sacred sites which are also important feeding grounds for the species (Newsome 1980). This helps ensure the persistence of the species and therefore an ongoing food source for the Aranda people. But as Berkes and Turner 
(2006) point out: not all societies experience this level of adjustment, adaptation can take a long time, and symbiosis is not permanent.

On Motungārara, it is likely that the population is now too small for any harvest to resume (Chapter Four). But, separation from the island and its muttonbirds may have prevented Ngā Takiwā from realising the condition of the population. Ngā Takiwā is currently in a predicament where realisation of the harvest impacts and/or population decline comes with access to the resource, yet access to the resource was denied and the population is in decline. This potentially denies Ngā Takiwā the ability to comprehend the implications of harvest, or the actions of the poachers, thereby limiting their ability to manage the situation and learn and adapt as appropriate. The state of the population may be the result of multiple factors not just associated with harvest, for example, fisheries bycatch and climate oscillations, the effects of which may be exaggerated in small populations (Shaffer 1981; Caughley 1994). Similar pressures are also facing the Tîti Island population. Nevertheless, long-term monitoring involving all stakeholders and active discouragement of poaching may provide an opportunity for each tribal group to have a low-level harvest for wānanga in the future.

\subsubsection{Conclusion}

The respective relationships between Ngā Takiwā and Ngāti Kuia and Motungārara and Titī Islands persist, despite a long absence of contact with the birds and the islands. Mātauranga Māori of sooty shearwaters also persists as does the iwis' desire to maintain their connection with each island.

The key issue now, is the preservation of the knowledge that remains regarding the relationships between the iwi, the birds and the islands, in particular the harvest of muttonbirds. While the issue of poaching remains, it is in both tribal groups' interest to work with the current island manager, the Department of Conservation, to come to an arrangement as to how the islands can be better managed and how the iwis' relationship with the Department can move forward. Iwi involvement in island and species management and the allowance of low level harvest (for example for wānanga) 
will maintain and further build on the iwis' relationship with the islands and the birds that breed on them. 


\section{Biological parameters of the sooty shearwater (Puffinus griseus) on Long and Tìtī Islands, Marlborough Sounds}

\subsection{Introduction}

The sooty shearwater (tītī, muttonbird, Puffinus griseus) is one of New Zealand's most abundant seabirds (Warham \& Wilson 1982). A recent study estimated the total population to number over 21 million birds (Newman et al. 2009b). It is also one of the last species still traditionally harvested by Māori (a practice known as muttonbirding; Kirikiri \& Nugent 1995; Taiepa et al. 1997). The breeding stronghold of this burrownesting, medium sized, trans-equatorial migrant is on islands off southern New Zealand. Small breeding populations (2\% of the New Zealand total; Newman et al. 2009b) also occur on offshore islands throughout New Zealand (Warham et al. 1982). In addition, small populations are found off south eastern Australia (Lane \& White 1983) and Chile (Marin 1984; Reyes-Arriagada et al. 2007).

Sooty shearwater populations have declined in recent decades (Scofield \& Christie 2002; Moller et al. 2009a). Population declines have been reflected in the annual muttonbird harvest (Lyver et al. 1999), in observed densities in the North Pacific (Veit et al. 1996; 1997), and in a marked reduction in burrow density on some islands (Scott et al. 2008). Major threats to seabird populations include high seas fisheries (Baker et al. 2002), introduced predators (Wanless et al. 2007; Jones et al. 2008), food-web perturbations (for example, Büßer et al. 2004) and increased frequencies of climate anomalies (Jenouvrier et al. 2009). Small sooty shearwater populations have disappeared from predator-free islands in the Hauraki Gulf in the last century (Scott et al. 2008). It is possible that the wider threats facing seabird populations could be 
threatening the persistence of smaller populations on the extremities of this species' breeding range.

The Marlborough Sounds have a number of seabird islands with breeding sooty shearwater populations. Sooty shearwaters were once an important seasonal source of food for iwi (Māori tribes) of the area. Harvest was outlawed with the 1953 Wildlife Act and ceased in the Marlborough Sounds area in the 1960s (Douglas 1963; Gaze 2000). Interest has been expressed by the iwi in resuming low level harvest to retain traditional knowledge. Titī Island has one of the largest sooty shearwater populations in the Marlborough Sounds, but there is no evidence that the sooty shearwater population is increasing following the cessation of harvest and the eradication of Norway rats (Rattus norvegicus) in the 1970s (Gaze 2000). The Long Island sooty shearwaters have never been studied. Biological information about these shearwater populations is needed to assist conservation managers in determining whether the populations can sustain harvest resumption.

In this study I sought to (a) determine the specific timing of the sooty shearwater breeding cycle in the Marlborough Sounds to compare with other sooty shearwater and closely related Puffinus populations; (b) obtain baseline biological parameters on which to model population trajectories (see Chapter Four); and (c) estimate population size on which to base future monitoring. The overall aim was to better understand the size and condition of these Marlborough sooty shearwater populations.

\subsection{Methods}

\subsubsection{Study site}

I collected biological data during the 2008/09 breeding season on Long and Titī Islands in the Marlborough Sounds (Fig. 3.1). Long Island ( $41^{\circ} 07^{\prime} S ; 174^{\circ} 17^{\prime} \mathrm{E}$ ) is a 142 ha Scenic Reserve near the entrance of Queen Charlotte Sound. The island was once farmed and all livestock and non-native predatory animals have been removed. The vegetation of the northern tip, where the sole sooty shearwater population is located, is comprised 
primarily of taupata (Coprosma repens), mountain flax (Phormium cookianum), and ngaio (Myoporum laetum). Undergrowth is sparse. Titî Island ( $40^{\circ} 57 \mathrm{~S}$; $\left.174^{\circ} 8^{\prime} \mathrm{E}\right)$ is a 32 ha Nature Reserve in outer Pelorus Sound. The island is pest free following the eradication of Norway rats (Rattus norvegicus) in the 1970s (Gaze 2000). Seabirds nest in gullies on the southern side. The canopy is dominated by taupata, ngaio, kohūhū (Pittosporum tenuifolium) and wharangi (Melicope ternata). The undergrowth consists primarily of shining spleenwort (Asplenium oblongifolium) and ongaonga (Urtica ferox).

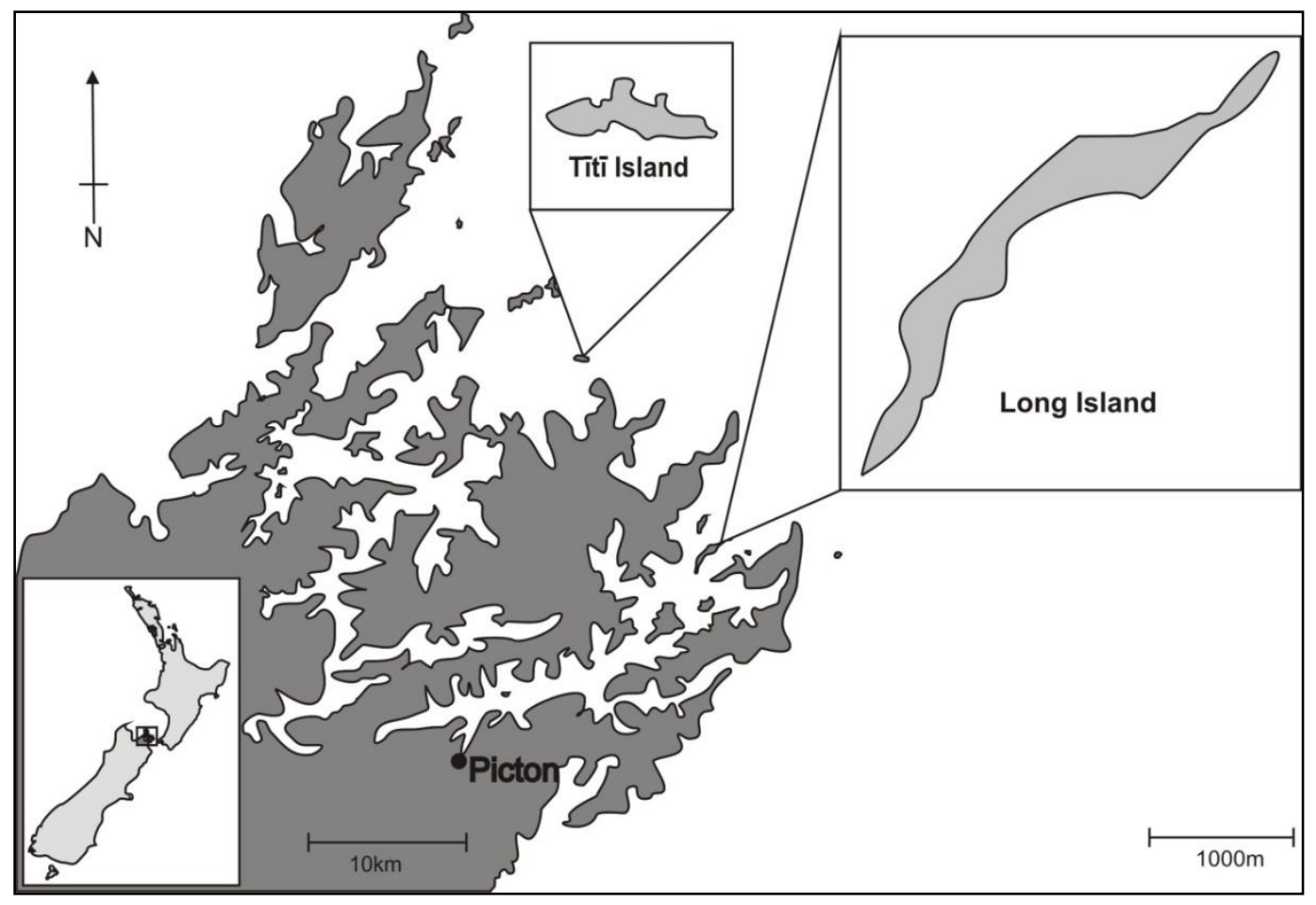

Figure 3.1: Map of study areas in the Marlborough Sounds, New Zealand. Seabird burrows occur on the southern side of Titī and the northern tip of Long Island. Each scale represents the different scales of the mainland and the islands.

\subsubsection{Study burrows}

Sooty shearwaters occur in small numbers at the northern tip of Long Island which made it possible to collect data from all active burrows. To test my confidence at having found most of the active burrows, I constructed an observation-nest curve modified from Odum and Kuenzler (1955). The curve $\left(R^{2}=0.862\right)$ demonstrated that the last $20 \%$ of the sampling effort revealed only one more active burrow. Therefore, a 
large amount of additional sampling would have been unlikely to significantly increase the active burrow tally. On Tîtī Island, data were collected from ten permanent 10x10m quadrats established by the NZ Wildlife Service in 1987 for long term monitoring (Gaze 2000).

\subsubsection{Data collection}

Biological data were obtained using two burrowscopes (Dyer \& Hill 1991). They were comprised of a video camera lit up either with infrared LEDs or white LEDs to illuminate the burrow. These were connected to the end of a hose that could be pushed down the burrow while projecting visual images to a screen. Burrowscopes are an effective method for determining burrow occupancy compared with other field methods (Hamilton 1998). However, several studies have revealed that their use can underestimate occupancy levels (Hamilton 1998; Hamilton 2000; Cuthbert \& Davis 2002; McKechnie et al. 2007). A correction factor can be used to improve the accuracy of data collected with a burrowscope (McKechnie et al. 2007) but I deemed this unnecessary given the repeated checking of each burrow, the low burrow densities and simple burrow structures (see results) on Long and Titī. These, in conjunction with the results of the observation-nest curve give me confidence to suggest that my assessment of burrow occupancy had a high level of accuracy.

Field work occurred on both Long and Titī from October 2008 to May 2009. This enabled me to study the birds from when they had returned from their migration to the North Pacific until the last fledgling had left the island. I only gathered data on Titī Island during the incubation and fledgling periods. A systematic search for study burrows was undertaken on Long Island in October and November and all active or potentially active burrows were uniquely marked using sheep ear tags $(n=94)$. Occasionally, previously undetected active burrows were discovered on later trips and subsequently monitored.

Laying dates were recorded from late November to early January. I also measured the length of each active sooty shearwater burrow using the hose of the burrowscope 
taped at $10 \mathrm{~cm}$ intervals. Burrows were measured from the entrance to the nesting chamber to the nearest $5 \mathrm{~cm}$. Hatching dates were recorded in mid-January. The hatching date was recorded as the day a chick was present when an egg was clearly sighted the day before.

Ten inspection holes were dug on Long Island over several days in the middle of March 2009 to access the chicks for weighing. The holes were dug through the topsoil, close to the nesting chambers of a sample of burrows. Holes were covered with a $30 \times 30 \mathrm{~cm}$ piece of plywood and/or a large rock or to ensure no drafts or seepage from rain could enter.

Chicks were weighed at the same time daily ( \pm 9 minutes) and their fledging dates recorded from mid April to early May. I defined fledging as the day the chick, following its three month development period, was no longer present in its burrow. The chicks were accessed either via an inspection hatch or by reaching directly down the burrow entrance $(n=7)$. They were placed in cloth bags and weighed with $1 \mathrm{~kg}$ or $1.5 \mathrm{~kg}$ pesola scales (10g and $20 \mathrm{~g}$ increments respectively). The bags were weighed after each chick was returned to its burrow to account for additional weight from moisture accumulation or excretion; the bag weight was then subtracted from the total.

Burrow densities were collected on Long Island using a $30 \mathrm{~m}$ tape measure. There is a large fluttering shearwater ( $P$. gavia) population present on the island but they are mostly found on slopes further down from the taupata. I measured two randomly selected areas within areas where taupata grew (108 and $\left.188 \mathrm{~m}^{2}\right)$ and counted all the burrows within. Densities on Titī were obtained from the ten 10x10m quadrats.

I plucked a minimum of six feathers from a sample of chicks I could access through the inspection hatches or by putting my arm down the burrows on Long $(n=18)$ and from putting my arm down burrows on Titī $(n=15)$. Feathers were placed in individual plastic bags (Grant 2001) and frozen. 


\subsubsection{Data analyses}

\subsubsection{Burrow length, density, egg laying, hatching and fledging}

Burrow densities and occupancy rates were calculated from measured areas. To determine laying and hatching dates of chicks I had missed, I calculated the incubation and the development periods from more detailed data of other nests and used them to calculate retrospectively from the hatching and fledging dates I did have. Eggs that did not hatch and whose lay date had not been determined were excluded from further analyses.

\subsubsection{Breeding success}

I considered breeding success to be the rearing of a chick from an egg to it leaving the island as a fledgling. Burrows with only one record of sooty shearwater adults present early in the breeding season and no confirmed sighting of an egg were removed from analysis as they were unlikely to have been breeding adults (Serventy 1967) or could have been burrow prospecting (Bradley et al. 1999).

Breeding success was measured using the 'Mayfield-40\%' method (Miller \& Johnson 1978; Johnson 1979) thereby enabling the use of all data. Each day a nest was in existence was considered 1 nest-day of exposure. Total exposure was calculated by adding together the exposure of nests that hatched and the exposure of nests that were destroyed. The daily survival rate (DSR) could be used to determine the probability of survival of any given period of time and was calculated using:

$$
D S R=1-\left(\frac{N D}{E S+E D}\right)
$$

Where ND is the number of nests destroyed divided by the combined total exposure of surviving (ES) and destroyed nests (ED). I used two periods of survival, the incubation period: from the day of laying to the day of hatching, and the development period: from the date of hatching to the date of fledging. Combining survival for both periods gave total probability of breeding success. 
Due to only gathering data on Titī Island during the incubation and fledgling periods, I combined the incubation and development time periods. I used the data from Long Island and calculated a single breeding success coefficient.

Standard errors (SE) and 95\% confidence intervals were calculated using the method developed by Johnson (1979), using the equation:

$$
\mathrm{SE}=\sqrt{\left(\frac{(\mathrm{E}-\mathrm{D}) * \mathrm{D}}{\mathrm{E}^{3}}\right)}
$$

Where $E$ is exposure and $D$ is the number of deaths for that exposure period.

\subsubsection{Post-fledging survival}

Determining post-fledging and juvenile survival rates in seabirds can be problematic. Mass at fledging can affect post-fledging survival and subsequent recruitment (Gaston 1997; Sagar \& Horning 1998). I therefore weighed a sample of chicks ( $n=15)$ to estimate baseline post-fledging survival.

If a chick was heavier than the day before, I interpreted this to mean it had been fed. Some chicks from the sample were unable to be weighed at fledging $(n=5)$. To estimate their weight on the day they fledged, the collective weight data of the rest of the sample was used. I first attempted non-linear regression analysis but the relationship was poor $\left(R^{2}=0.302\right)$. I therefore took an alternative approach and divided chick weights into groups of $100 \mathrm{~g}$ and determined the average daily weight lost while each chick was in each weight group. The average weight lost was then subtracted from the weight of each chick whose weight at fledging was unknown. The amount subtracted varied according to the last weight of the chick and the number of days between its last weighing and the day it fledged.

The final weights (actual and estimated) of surviving chicks were then used to calculate a baseline post-fledging survival rate for the Long Island population. The proposed minimum weights of Richdale (1963) were used for an 'optimistic' survival rate (OS) and Sagar and Horning (1998) for 'pessimistic' survival (PS) using: 


$$
\mathrm{OS}=\left(\frac{\mathrm{x}>455 g}{\mathrm{n}}\right) * 100 \text { and } \mathrm{PS}=\left(\frac{\mathrm{x}>564 g}{\mathrm{n}}\right) * 100
$$

Where $\mathrm{x}$ is the number of chicks weighing over the required weight and $\mathrm{n}$ is the total number sampled.

\subsubsection{Population estimates}

I considered the number of eggs laid to be a direct measure of breeding pairs present in the population this season. I multiplied the number of eggs by 4.84 (Newman et al. $2009 b)$ to account for the juveniles, pre-breeders and non-breeding adults absent from the breeding population in any given season (Brooke 2004).

On Titī Island I estimated the number of breeding pairs using occupancy rates from the $10 \times 10 \mathrm{~m}$ quadrats multiplied by the total number of potential shearwater burrows estimated by Baker et al. (2009). The resulting number was subsequently placed into the population equation used for Long Island to get the population estimate for Titi Island.

\subsubsection{Sex ratio}

It has been suggested that wandering albatrosses (Diomedea exulans) adjust the sex of their offspring to maximise their survival post-fledging (Blanchard et al. 2007). In order to determine the importance of sex ratio on Long and Tïti Islands, I had the feather samples genetically sexed. There is one genetic test universal to all birds except ratites that can be used to identify sex (Ellegren 1996; Griffiths et al. 1998). Polymerase chain reaction primers are used to isolate and amplify the $\mathrm{W}$ linked chromo-helicase-DNAbinding gene. When compared with the DNA amplified from the Z chromosome, the sex is easily identifiable (Griffiths et al. 1998). The sexes of my samples were determined at the Equine Parentage and Animal Genetic Services Centre (Massey University, Palmerston North). 


\subsection{Results}

\subsubsection{Burrow length and density, egg laying, hatching and fledging}

The average length of the sooty shearwater burrows on Long Island was $83.6 \mathrm{~cm} \pm$ $4.3 \mathrm{~cm}$ (SE) (range 35-170, $n=51$ ). A few burrows had small chambers diverting off the main burrow, presumably where the bird had attempted to dig but had stopped for unknown reasons. All burrows containing sooty shearwaters had a single nesting chamber. Nearly all burrows (98.5\%) had a single entrance and $1.5 \%$ had two entrances. The average burrow length on Titī Island was $80.6 \mathrm{~cm} \pm 5 \mathrm{~cm}$ (range 40-180, n=34). Seven percent of burrows sampled had two nesting chambers extending from the same entrance and $3 \%$ had two entrances. There was a trend for longer burrows to have a higher probability of fledging success and the pattern was nearly statistically significant (ANOVA 95\% $p=0.054, n=85$ ).

Burrow densities within the sooty shearwater breeding areas were 0.138 burrows per $\mathrm{m}^{2}$ on Long Island and sooty shearwater densities were 0.061 burrows per $\mathrm{m}^{2}$. On Tîtī, total burrow densities were 0.139 per $\mathrm{m}^{2}$. Burrows occupied by sooty shearwaters were 0.064 per $\mathrm{m}^{2}$.

On Long Island, the incubation period was 54.3 days \pm 1 day (SE) (range 53-56, n=4) and the development period was $104.5 \pm 2$ days (range 98-109, n=17). Eighty nine percent of the egg laying dates were estimated from hatching using the incubation period to calculate retrospectively. Nonetheless, the pattern during the incubation period suggests egg laying occurred over a 16 day period between 20 November - 5 December $(n=37)$. Eighty one percent of chicks hatched between 17-23 January (mean 20 January \pm 3.5 days, range $13-28$ January, $n=37 ;$ Fig. 3.2). The mean fledging date was 4 May \pm 4.3 days (range 26 April - 12 May, $n=28$; Fig. 3.3).

\subsubsection{Breeding success}

On Long Island the probability of an egg surviving through to hatching was slightly lower than that of a chick surviving through to fledging (hatching success $0.66195 \% \mathrm{Cl}$ 


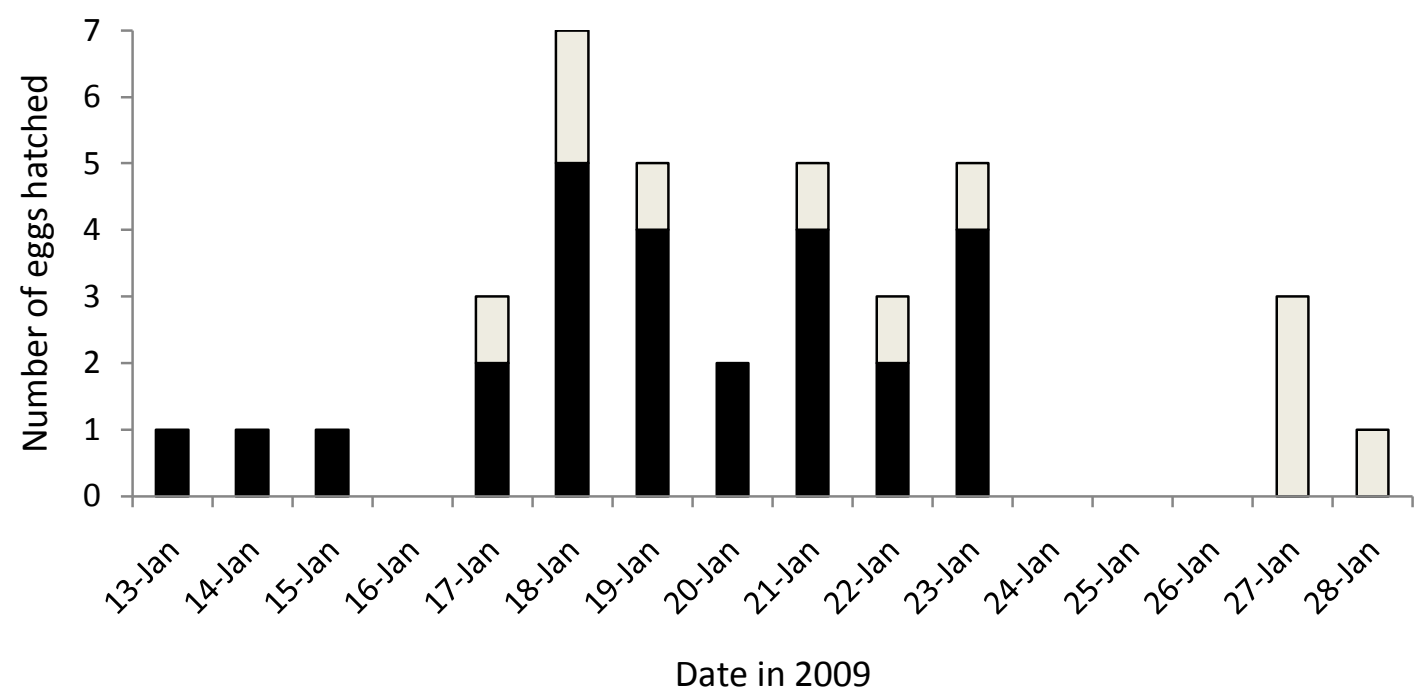

Figure 3.2: Eighty one percent of sooty shearwater chicks hatched on Long Island between 1723 January. The mean hatching date was 20 January \pm 3.5 days. Black bars represent observed hatching, light bars represent estimates. Bars combined represent totals for the island.

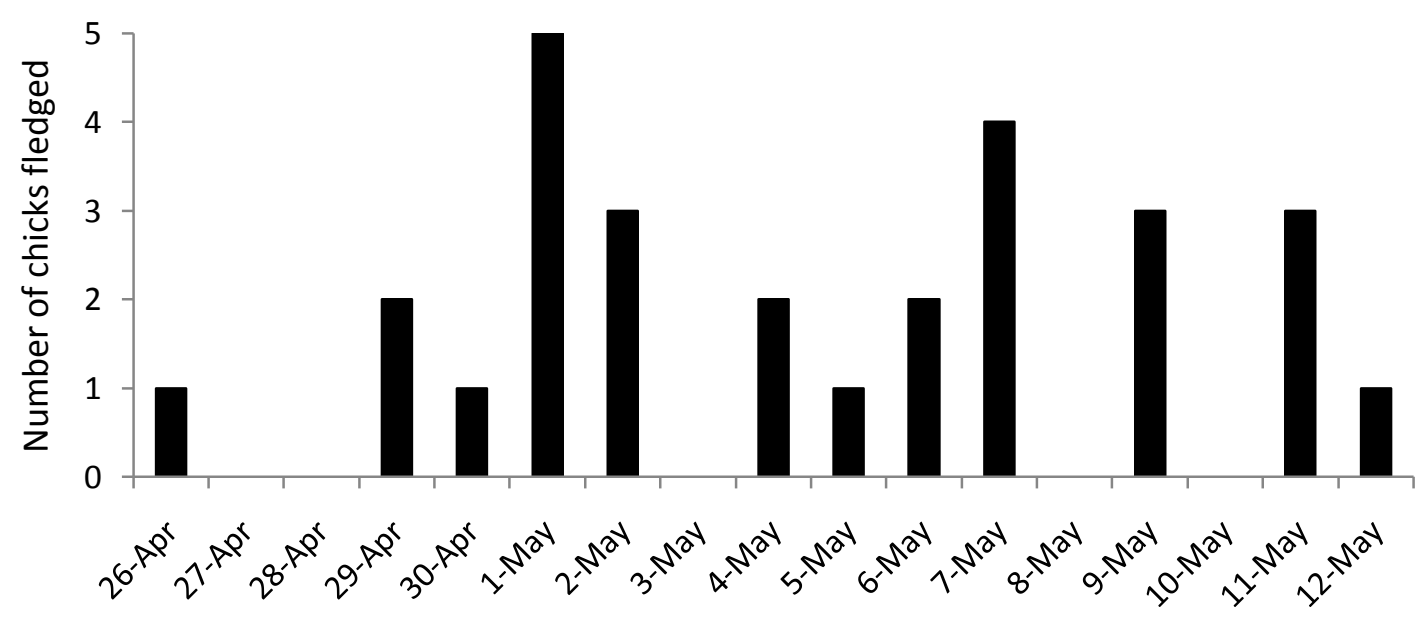

Date in 2009

Figure 3.3: Fledging dates of sooty shearwater chicks on Long Island. The mean fledging date was 4 May \pm 4.3 days. 
Causes of egg and chick failure were difficult to determine. Sometimes the egg and incubating adult would vanish within 24 hours of the last sighting, but other times little blue penguins would move in apparently evicting the incubating sooty shearwater adult. Despite attempting to keep my disturbance to a minimum, my presence caused at least one egg failure through disturbing an incubating adult although it is impossible to quantify my total impact this season. Of the chicks that hatched but failed to survive, approximately $60 \%$ were provisioned for a minimum of three weeks before dying. Those that died early in the season were close to or just inside the burrow entrance, a possible sign their parents had stopped feeding them and they had exited the nesting chamber in search of food. It was impossible to determine whether chicks were abandoned or if one or both parents died while out foraging. Almost $25 \%$ of the chicks that did not survive are known to have died of starvation - the last one surviving until its $90^{\text {th }}$ day. At least one fledgling was killed by a raptor (likely an Australasian harrier: Circus approximans), the fledgling's body was picked clean and a harrier coloured feather was found beside the remains.

\subsubsection{Post-fledging survival}

The chicks were fed with decreasing regularity in the weeks leading up to fledging. As a chick became lighter, its daily weight loss decreased with the length of time since its last feed. Over $61 \%$ of the chicks sampled were last fed approximately 91 days after hatching. The last chick to be fed was fed on 3 May, which was 96 days after hatching. The chick fledged 7 days later.

Weight at fledging of all chicks (actual and estimated, $\mathrm{n=16}$ ) ranged from 399 to $995 \mathrm{~g}$ with a mean weight of $737.2 \mathrm{~g} \pm 40.8$ (SE). The mean fledging weight was $90 \%$ of the average adult weight of $819.1 \mathrm{~g} \pm 76$ (Warham et al. 1982).

Chicks that fell below the optimistic threshold weight for survival, also fell below the pessimistic level ( $n=2 ;$ Fig. 3.4). Therefore given weight at fledging, it is expected that $87.2 \%$ of the chicks that fledged off Long Island in the $2008 / 09$ season could survive to return and breed as adults. 


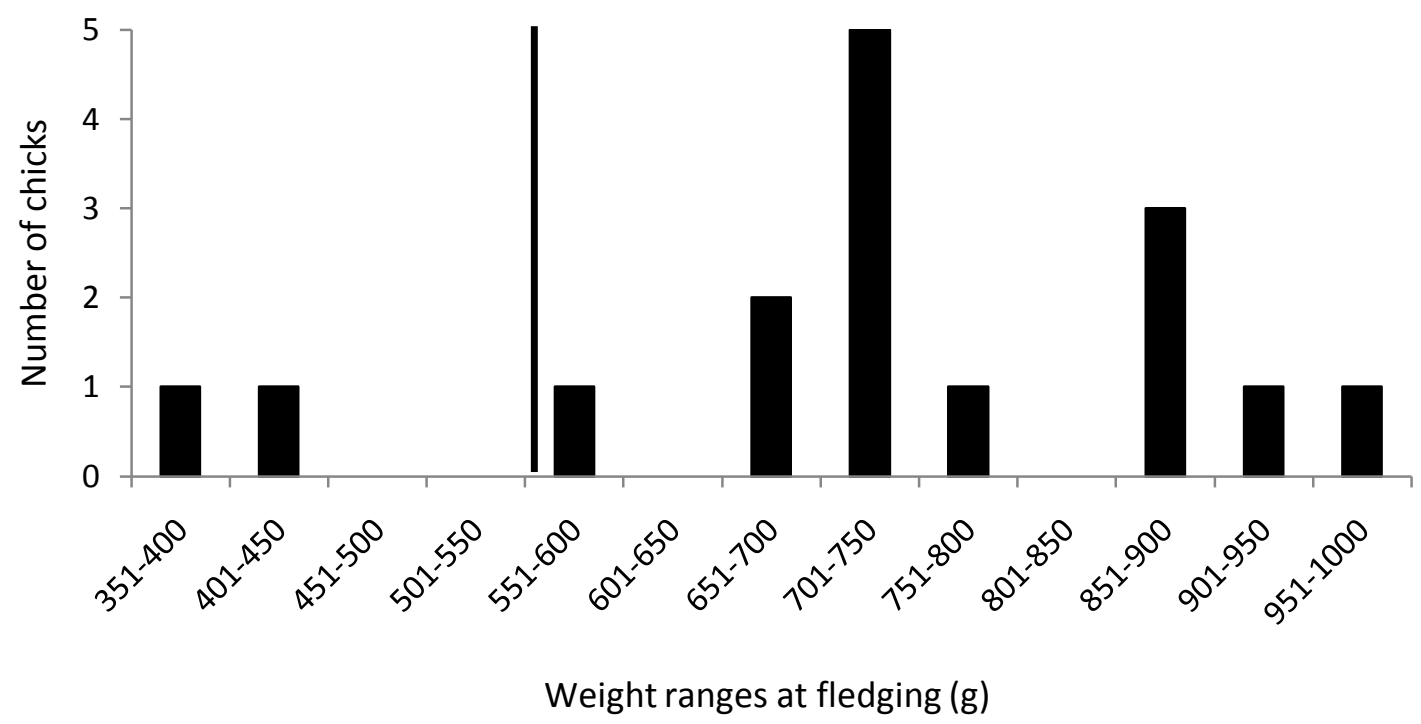

Figure 3.4: Tally of sooty shearwater chick weights at fledging. The two chicks to the left of the black line are not expected to return due to their weight being below the optimistic and pessimistic threshold weights for survival.

\subsubsection{Population estimates}

A total of 60 eggs were estimated to have been laid on Long Island over the 2008/09 season. A population of 60 breeding pairs, multiplied by the population estimator of 4.84 (Newman et al. 2009b), gives an estimated population size of 291 birds. Of the 2,814 total potential shearwater burrows estimated to be present on Titī Island (Baker et al. 2009), the total number of potentially occupied burrows (in other words, breeding pairs) came to 1,296 giving an estimated total population size of approximately 6,273 birds.

\subsubsection{Sex ratio}

Feather samples were taken from 18 Long Island chicks (62\% of the chicks that fledged). Eleven were male; seven were female giving a 1.6:1 male bias. Only 15 feather samples were taken from Titī Island, representing 1.2\% of the estimated 1,300 occupied sooty shearwater burrows this season. The sex ratio was four males to eleven females giving a 1:2.8 ratio skewed towards females. 


\subsection{Discussion}

\subsubsection{Breeding phenology}

Sooty shearwaters, along with other migratory petrels, have highly synchronous annual cycles possibly associated with their yearly trans-equatorial migration (Warham et al. 1982). Not surprisingly, I found the breeding chronology to be similar to other sooty shearwater populations occurring at much higher latitudes in New Zealand (Table 3.1). A similar synchrony occurs in other migratory Puffinus species. For example up to $90 \%$ of short-tailed shearwater eggs are laid \pm 3 days of the mean laying date with all eggs laid over a 16 day period in November (Meathrel et al. 1993). A similar phenology is also apparent in the great shearwater (Puffinus gravis; Cuthbert 2005) and flesh-footed shearwater (McClellan 1996; Powell et al. 2007).

Burrow geometry is likely to be influenced by soil depth, structure and vegetation type although these factors are not always significant (Powell et al. 2007). Burrow length on Long and Titĩ Islands is comparable with the $90 \mathrm{~cm} \pm 4 \mathrm{~cm}$ average of the wedge-tailed shearwater (Puffinus pacificus) on Heron and Erskine Islands (Dyer \& Hill 1992) and have similar construction but slightly shorter burrow lengths than the flesh-footed shearwater in Australia (Priddel et al. 2006; Powell et al. 2007).

Burrows on Long and Titī Islands did not have the high levels of bifurcation and complexity found in burrows on islands off southern New Zealand where high numbers of sooty shearwaters breed (Hamilton 2000). A study on densely burrowed Northeast Island, in the Snares group revealed burrow systems with multiple entrances and burrow connections, the most complex connected 21 entrances and contained 23 nests (Hamilton 2000). In addition, only 5\% of burrow entrances sampled in that study led to a single burrow that was not connected to another (Hamilton 2000). The lack of complexity on Long and Titī compared with Northeast Island is possibly due to the much smaller populations and therefore reduced competition for space. Mean burrow densities occupied by sooty shearwaters on Long and Titī were 0.061 and 0.064 burrows per $m^{2}$ respectively. These are much lower than the range of between 0.57 
Table 3.1: Comparison of Long Island sooty shearwater breeding dates and biological parameters with those of three different island populations that lie south of the South Island. Mean presented in brackets where available.

\begin{tabular}{|c|c|c|c|c|}
\hline & $\begin{array}{l}\text { Long Island } \\
\left(41^{\circ} \mathrm{S} ; 174^{\circ} \mathrm{E}\right) \\
\text { (this study) }\end{array}$ & $\begin{array}{l}\text { Snares Islands } \\
\left(48^{\circ} \mathrm{S} ; 166^{\circ} \mathrm{E}\right) \\
\text { (Warham et al. } \\
1982)\end{array}$ & $\begin{array}{l}\text { Whero Island } \\
\left(46^{\circ} \mathrm{S} ; 168^{\circ} \mathrm{E}\right) \\
\text { (Richdale 1954, } \\
1963 \text { ) }\end{array}$ & $\begin{array}{l}\text { Macquarie Island } \\
\left(55^{\circ} \mathrm{S} ; 159^{\circ} \mathrm{E}\right) \\
\text { (Brothers 1984) }\end{array}$ \\
\hline Egg laying & $\begin{array}{l}20 \mathrm{Nov}-5 \mathrm{Dec} \\
(27 \mathrm{Nov})\end{array}$ & $\begin{array}{l}66 \% \text { between } 20- \\
25 \text { Nov ( } 22 \text { Nov) }\end{array}$ & - & $\begin{array}{l}\text { Peak between } 18 \text { - } \\
20 \text { Nov*}^{*}\end{array}$ \\
\hline Egg hatching & $\begin{array}{l}\text { 17-23 Jan } \\
\text { (20 Jan) }\end{array}$ & $\begin{array}{l}66 \% \text { between } 11- \\
16 \text { Jan }\end{array}$ & $\begin{array}{l}16 \text { Jan }-4 \text { Feb } \\
\text { (24 Jan) }\end{array}$ & 10-26 Jan \\
\hline Chick fledging & $\begin{array}{l}26 \text { Apr - } 12 \text { May } \\
\text { (4 May) }\end{array}$ & $\begin{array}{l}\text { 10-30 Apr } \\
(21 \mathrm{Apr})^{* *}\end{array}$ & $\begin{array}{l}19 \text { Apr - } 12 \text { May } \\
\text { (2 May) }\end{array}$ & 18 Apr - 9 May \\
\hline $\begin{array}{l}\text { Incubation } \\
\text { period }\end{array}$ & $\begin{array}{l}\text { 53-56 days } \\
\text { (54.3 days) }\end{array}$ & 53 days & 56 days*** & - \\
\hline $\begin{array}{l}\text { Chick rearing } \\
\text { period }\end{array}$ & $\begin{array}{l}\text { 98-108 days } \\
\text { (104.5 days) }\end{array}$ & - & $\begin{array}{l}\text { 86-106 days } \\
\text { (97 days) }\end{array}$ & $\begin{array}{l}\text { 82-119 days } \\
(100.5 \text { days })^{* * * *}\end{array}$ \\
\hline
\end{tabular}

* Estimated using data from Warham et al. (1982).

** Estimate. Authors conceded dates more likely to resemble Richdale (1963).

$* * *$ Estimate.

$* * * *$ Chick rearing period not calculated. I used the author's data to estimate rearing period.

and 1.23 entrances per $\mathrm{m}^{2}$ on Northeast Island (Scott et al. 2008) or the density of 0.33 per $\mathrm{m}^{2}$ on Pohowaitai, an island off the Rakiura coast of similar size to Titī and harvested for sooty shearwaters (Charleton et al. 2009). In contrast, Whenua Hou has a density of 0.09 burrows per $\mathrm{m}^{2}$, hypothesised to be low due to contrasting vegetation when compared with other seabird islands in the area (Charleton et al. 2009). Baker et al. (2009) conducted a flesh-footed shearwater (P. carneipes) study on Titī in January 2009. They estimated total burrow densities on Tïtī to be 0.08 per $\mathrm{m}^{2}$. A likely reason for their lower estimate is because they used $2 \mathrm{~m}$ wide strip transects that sampled a larger area than the $10 \times 10 \mathrm{~m}$ quadrats I used. Using their data in addition to my own may give a clearer overall picture for the breeding seabird populations on Titī. In addition, the soil on Long may not have been suitable for complex burrow systems. 
Large open areas under the taupata were clear of burrows and in many cases rolls of rusting chicken wire lay nearby which implies that the area is recovering from relatively recent human interference.

\subsubsection{Breeding success and post-fledging survival}

Although I only have data from one breeding season from two islands, overall breeding success for both Long and Titī falls within the annual variations observed on the Snares between 1997-99 (mean 0.35, range 0.07-0.67) and Whenua Hou between 1997-99 and 2003-05 (mean 0.76, range 0.37-0.90; Newman et al. 2009a). My estimates also align closely with mean breeding success of $48 \pm 2 \%$ during the $1993 / 94$ to $1997 / 98$ breeding seasons observed on Tuhawaiki Island, a predator-free offshore islet (Jones et al. 2003). Contrasting levels of breeding success may be attributed to different foraging areas and environmental conditions in spatially disparate populations (Newman et al. 2009a). A 16\% difference between breeding success on Titī and Long is not as great as the $83 \%$ difference observed between the Snares and a much more distant Whenua Hou during the 1998 breeding season (Newman et al. 2009a) but highlights that even populations that are geographically close with similar population densities can experience different ecological effects that impact on their breeding success. It is unknown how the breeding success I recorded on Long and Titī fits in to the general pattern for each island. The rates are similar to the average found on the Snares but are at the lower end of the range for Whenua Hou. Given the similarity in burrow densities between Long, Titī and Whenua Hou, it is possible that breeding success of these three islands may be more similar to each other than to the Snares where densities are high (Scott et al. 2008; Charleton et al. 2009). Therefore the estimates from 2008/09 may be an underestimate of the average. However, marine food-web interactions are complex and it is very difficult to extrapolate trends from single factors when a number of factors may be acting on the population. For example, sooty shearwater population dynamics may be influenced by the availability and abundance of krill (Cruz et al. 2001), but it is unknown whether there is a direct link 
between food web changes and poor breeding seasons (Kitson et al. 2000). The sooty shearwater has a variable interannual diet (Kitson et al. 2000) and will forage over $2000 \mathrm{~km}$ from its breeding area (Shaffer et al. 2009). The birds' ability to travel vast distances and forage for long periods (Weimerskirch 1998) may counteract any spatial inconsistencies in food availability in any given year (Shaffer et al. 2009) but more data are needed to determine if this pattern holds true for the Marlborough Sounds. Of six birds tracked with archival tags from Mana Island, near the Marlborough Sounds, only one bird travelled to more productive oceanic waters to the southeast of the island, the rest remained in less productive coastal waters (Shaffer et al. 2009). Chicks being fed low quality food led to chick deaths and reduced breeding success in Cape gannets (Morus capensis; Grémillet et al. 2008) and common guillemots (Uria aalge; Wanless et al. 2005) and low food availability has been attributed to annual fluctuations in breeding success in Wilson's storm petrels (Oceanites oceanicus; Büßer et al. 2004). The implication is that if adult birds from the Marlborough Sounds are not accessing the oceanic waters off southern New Zealand, this could negatively impact chick survival. Further studies are needed to determine how the populations' distance from the centre of the species' breeding range impacts breeding success rates and chick condition relative to populations at higher latitudes.

In addition, a large proportion of the chicks that did not survive on Long and Titi probably died of starvation. It is highly likely that chicks that starved were abandoned too early and probably had at least one parent die at sea (G. Taylor pers comm.). Factors such as storm events or pathogens could have contributed to the deaths of the adults or it could implicate the impact of fisheries (i.e. adults caught in fishing gear) on the breeding success of these small island populations. Some methods have been developed to deter sooty shearwaters from scavenging from fishing trawlers (Robertson et al. 2006) but the effects of these mitigation methods, along with fisheries generally, are difficult to quantify for this species (Uhlmann et al. 2005).

Post-fledging survival is often over-looked in avian studies. Reproduction is often considered successful once the chick has fledged (Keedwell 2003). A common method 
of estimating post-fledging survival is to use the weight at fledging. This is an indicator of chick condition and has a direct impact on an individual's chance of survival and subsequent recruitment into the breeding population (Sagar \& Horning 1998; Mougin et al. 2000). Adult sooty shearwaters depart on their migration regardless of the condition of their chick (Richdale 1963). Sagar \& Horning (1998) suggest the proportion of fledglings surviving increases with mass exceeding $564 \mathrm{~g}$, yet some may survive with lower fledging weights (Richdale 1963). The small sample size from Long Island could not be analysed sufficiently to allow it to be compared with the methods of Sagar \& Horning (1998). Analysis of the chick weight data was also impeded by gaps between weighings and the large number of chicks that were not fed during the sampling period, probably due to their parents having already left on their migration. In addition, none of the chicks were banded making future recapture analysis impossible. Nonetheless, a relatively small percentage of chicks (12.5\%) were seriously underweight.

\subsubsection{Sex ratio}

It is hard to determine the importance of the sex ratio bias discovered in the results with a small sample size and only one season's data. In the wandering albatross the sex ratio at hatching is influenced by the age and reproductive quality of the parents (Weimerskirch et al. 2005). In common terns (Sterna hirundo) at Banter See, offspring are female biased but this is reversed at recruitment (Becker et al. 2008). The skewed sex ratios observed on Long and Titī were probably a result of the small sample size. The sex ratio for Tìtī had a larger bias than Long but the sample was a much smaller representation of the population. Not enough is known about whether sex biased mortality occurs at each life stage in the sooty shearwater. Regardless, these limited data do not suggest an extremely skewed sex ratio among chicks on either Titī or Long Island.

\subsubsection{Population estimate}

Estimating population sizes of burrowing seabirds is inherently difficult. Complications include sampling methodology (Hamilton 2000; McKechnie et al. 2007), presence of 
juvenile, pre-breeding and transient birds (Newman et al. 2009b) and the often steep, fragile and sometimes inaccessible island habitats the birds occupy. In addition, breeding populations fluctuate in size from year to year, likely reflecting the influence of environmental variability and the trade-off between reproduction and survival (Stearns 1976; Jenouvrier et al. 2003). Richdale (1963) estimated that only one third of the sooty shearwater population of Whero Island actually bred on Whero Island in any given season. The rest were what he termed 'unemployed' (Richdale 1963). Brooke (2004) suggested a minimum of three birds existed for every seabird breeding pair but that this should be increased to five for particularly long-lived species. Newman et al. (2009b) tested this suggestion and concurred with a model multiplier of 4.84 for sooty shearwaters. I used the model multiplier to estimate both island population sizes but I also consider the number of breeding pairs to be an important indicator of population trends because it is easier to quantify and has direct implications for population growth rates and estimates (Wanless et al. 2009).

The Long and Titī population estimates could be underestimates. Fluctuations in sooty shearwater harvest rates and annual burrow occupancy rates correlate significantly with Southern Oscillation anomalies when lagged by one year (Lyver et al. 1999). The extent of harvest rate fluctuations can accurately predict the onset of an El Niño or La Niña event and its intensity (Lyver et al. 1999). The 2009 sooty shearwater harvest was one of the worst in living memory (Newman 2009) and an El Niño event began in October 2009 (Australian Bureau of Meteorology, Canberra, Australia). It is feasible that the sooty shearwater populations of the Marlborough Sounds were affected during the period of this study and the population estimates likely reflect that. More importantly, extreme climate anomalies are predicted to increase in frequency in the future which may have serious implications for small populations such as that of Long Island which face additional external pressures such as fisheries bycatch, potentially affecting the population growth rates. These impacts will be investigated and discussed in Chapter Four. 
It is difficult to infer any possible population trends on Titī by comparing estimates from earlier studies because they used different methodologies. Similar issues have been documented in attempts to determine wedge-tailed shearwater population trends using historic data (Dyer et al. 1995). A population estimate conducted in December 1969 intensively sampled three of an estimated seven breeding areas, determining occupants solely by smell (Bell 1969). The report concluded that Titī had a maximum possible total of 1500 burrows of which 600-650 were active petrel burrows made up of $81.3 \%$ sooty shearwaters and $18.8 \%$ flesh-footed shearwaters (Bell 1969). This would put the 1969 population at between 488 and 529 breeding pairs, less than half my estimate of 1,296 . Gaze (2000) found no detectable increase in the number of active burrows on Titī between 1987 and 1998 which adds further doubt to a population increase from approximately 500 pairs in 1969 to approximately 1,300 in 2009. Similar to Bell (1969), Gaze's study also primarily relied on smell to identify burrow occupants. Some studies have found error associated with the sole use of field signs to determine burrow occupancy (Hamilton 1998; Cuthbert \& Davis 2002). However, in some cases there has been no significant difference between the average occupancy status detected by the use of field signs compared with burrowscopes, but those found to be occupied by field signs were not necessarily those confirmed by the burrowscope (Cuthbert \& Davis 2002; Geary 2009). While the occupancy rates I estimated were similar to those of Bell (1969), I was constrained by the use of the ten $10 \times 10 \mathrm{~m}$ quadrats which only covered an estimated $2.4 \%$ of the total colony area (Baker et al. 2009) and may not be a true representation of burrow densities and occupancy rates for the island. In addition, my total population estimate for both islands is likely to be larger than earlier estimates due to the fact that I have included the existence of birds not present or not breeding on the islands this season.

\subsubsection{Conclusion}

The breeding biology of the Long and Titī Islands' sooty shearwater populations is similar to populations from the species' breeding stronghold off southern New Zealand. 
However, it is likely that the impacts of climate anomalies, fisheries and their location on the fringe of the species' breeding range are exacerbated given the small size of these populations.

The sooty shearwater populations of the Marlborough Sounds are good populations on which to conduct research. They are small, relatively accessible, and a number occur within a small spatial scale which may assist determining parameters such as immigration rates. Although baseline biological data are provided here, longer term studies using standardised methods are needed to determine demographic parameters particular to the Marlborough Sounds to help assess the populations' status, the interactions occurring among them and guide future management decisions. 


\section{The viability of two small sooty shearwater (Puffinus griseus) populations and their resilience to customary harvest}

\subsection{Introduction}

Extinction may be a real threat to small populations with low growth rates that are subject to highly variable environments (Lande et al. 1995). The four primary contributors to the extinction of small populations include demographic, environmental and genetic stochasticity and catastrophes (Shaffer 1981). Populations may be naturally small due to their environmental distribution or could be small as a result of human influence from hunting, habitat destruction and introduced predators. For example, the Lord Howe Island woodhen (Gallirallus sylvestris) population was restricted by the small size of its island home. The introduction of pigs to the island accompanied with human hunting therefore had devastating consequences on a small, spatially limited population (Miller \& Mullette 1985). Populations can eventually become so small their vulnerability to deterministic and stochastic factors may drive them towards extinction unless humans intervene. For example, the world's kakapo (Strigops habroptilis) population numbered approximately 50 birds in the 1970s. High levels of inbreeding have been attributed to the low productivity now observed in the species and the necessity for intensive management by conservation staff (Elliott et al. 2006; Jamieson et al. 2006).

Small or declining populations are a priority for conservation managers. A key issue is understanding the causes of long-term population decline but causes of decline (both natural and human induced) are numerous and vary considerably between taxa. For example, predation of juvenile tuatara (Sphenodon punctatus) by introduced kiore 
(Rattus exulans) has prevented recruitment on Taranga Island, New Zealand. If kiore are not removed, the remnant population of 44 adults is predicted to collapse (Towns et al. 2007). But unlike tuatara, multiple pressures including fisheries and introduced predators are having serious impacts on the world's population of the Balearic shearwater (Puffinus mauretanicus). If current pressures continue unabated, the mean time to extinction of the species is estimated to be 40.4 years (Oro et al. 2004). Specific life-history characteristics can contribute to the vulnerability and rate of decline of a species or population (Sæther et al. 2005a). Seabirds, in particular Procellariiformes, have these distinctive life-history characteristics. For example, they have low fecundity, long generation times and are sensitive to perturbations in adult survival rates (Warham 1990, 1996; Hunter et al. 2000a). In addition, the typically low maximum annual population growth rates in seabirds limit their ability to sustain high levels of additional mortality and recover quickly from depletion (Dillingham \& Fletcher 2008).

Seabirds have been exploited for their eggs, meat, feathers and guano for centuries, yet the impact of harvest has rarely been documented (Feare 1984). While some communities no longer rely on subsistence seabird harvest (Baldwin 1974; Oka 1994; Baldwin 2009), other communities continue the practice to maintain a cultural tradition (Beatty 1992; Lyver et al. 2008a). When not managed properly, the overharvest of eggs, chicks or adult birds has led to population declines or extirpations (Feare 1976, 1978; Haynes 1987). Nonetheless, there are a number of examples where harvesting has continued for long periods of time, presumably at sustainable levels (Beatty 1992; Oka 1994).

Indigenous Māori communities have harvested wildlife from the time of their first settlement in New Zealand (Kirikiri \& Nugent 1995). While harvesting is no longer relied on for survival, it is of cultural importance. Mana (prestige or standing in the eyes of others) is gained by being able to provide traditional foods to guests and is taken as a sign that the community is managing their resource well (Kirikiri \& Nugent 1995; Lyver et al. 2008a; Lyver et al. 2009). Sooty shearwaters (Puffinus griseus) are one of only two 
seabird species still traditionally harvested by Māori in New Zealand (Kirikiri \& Nugent 1995). This species occurs in high numbers and is harvested off southern New Zealand. Sooty shearwaters were once an important seasonal source of food for iwi (Māori tribes) in the Marlborough Sounds as well, but have not been legally harvested in the Marlborough Sounds since the 1960s (see Chapter Two). Desire to resume harvest for wānanga (learning forums) has been expressed by members of two different tribal groups from the area: Te Atiawa Manawhenua ki te Tau Ihu (Te Atiawa) and Ngāti Kuia. Before such harvest is considered, it is important to establish the viability of the populations and their ability to sustain harvest.

Population viability analysis (PVA) is an important conservation tool that estimates the importance of particular life-history parameters and stochastic events on the persistence of populations (Shaffer 1981; Boyce 1992). Population viability analysis can explore the consequences of a range of scenarios to provide advice to conservation managers (Reed et al. 1998). Previous studies have used PVA to test the consequences of the removal of animals for translocation (Brook et al. 2002b), increasing frequency of climate anomalies (Vargas et al. 2007) and the implications of maintaining single populations compared with metapopulations in species conservation (Reed et al. 1998). In this study, I used PVA to evaluate the population growth rates and likelihood of extinction of sooty shearwater populations on Motungārara and Titī Islands in the Marlborough Sounds, New Zealand to determine their resilience to the resumption of a low-level of customary harvest. Specifically, I addressed the following questions (a) are the populations currently increasing in size; (b) would historic exploitation levels have been sustainable, and; (c) can the populations sustain low levels of future harvest.

\subsection{Methods}

\subsubsection{Study site}

Motungārara $\left(41^{\circ} 06^{\prime} \mathrm{S} ; 174^{\circ} 19^{\prime} \mathrm{E}\right)$ is a small (<2ha) island located in Onehunga Bay off Arapawa Island, Queen Charlotte Sound. The seabird burrowing habitat is dominated 
by taupata (Coprosma repens), poroporo (Solanum laciniatum) and ngaio (Myoporum laetum), with a dense undergrowth of ongaonga (Urtica ferox) and shining spleenwort (Asplenium oblongifolium). The main ridge of the island is shaded by thick groves of karaka (Corynocarpus laevigatus). See Chapter Three for a description of Titī and my field methods. Also see Chapter Two for a map of study location.

\subsubsection{Data collection and analysis}

I collected sooty shearwater biological data from both the field and the published literature (Table 4.1). Data collection on the Motungārara sooty shearwater population was not feasible due to the size, terrain and exposure of the island to the prevailing northerly wind. Therefore, data from a sooty shearwater population on nearby Long Island (Chapter Three) were used as a substitute. Where sooty shearwater data were unavailable, I used parameters from the closely related short-tailed shearwater (Puffinus tenuirostris). Explanations and justifications for this are provided in the next section. I analysed the data using VORTEX version 9.96 which enabled incorporation of stochastic processes such as breeding success, and varying levels of harvest on each population (Lacy 1993). VORTEX has been thoroughly scrutinised in the literature and population predictions have been shown to be accurate when adequate data are available (Brook et al. 1997; 1999; 2000). I considered each island a population even though each island was subdivided into many colonial areas. I conducted 1000 iterations of each simulation to determine the likelihood of the population becoming extinct over a 100 year period. Extinction was defined as only one sex remaining.

\subsubsection{Biological parameters for VORTEX}

The following sections provide an explanation of the biological parameters used to model populations of sooty shearwaters on Motungārara and Tîtī Islands in VORTEX.

\subsubsection{Inbreeding depression}

It is unknown if the Titī and Motungārara populations (or sooty shearwaters in general) are affected by inbreeding. Wandering and Amsterdam albatrosses (Diomedea exulans 
and $D$. amsterdamensis) have naturally low genetic diversity, with no apparent detriment to their survival (Milot et al. 2007). I did not include inbreeding depression in the VORTEX simulations.

Table 4.1: Initial sooty shearwater parameters incorporated into models for Titī; and Motungārara Island respectively. All data are referenced except where the value originated in this chapter. Unless otherwise stated, all standard deviations were set to zero.

\begin{tabular}{|c|c|c|}
\hline Parameter & Value & Reference \\
\hline Inbreeding depression & N/A & \\
\hline Environmental concordance & Yes & \\
\hline Catastrophes & 0 & \\
\hline Breeding system & Long-term monogamy & \\
\hline Age of first reproduction & 8 & (Newman et al. 2008; 2009b) \\
\hline Max. age of reproduction & 40 & \\
\hline Broods and progeny per brood & 1,1 (both islands) & (Warham 1990) \\
\hline Sex ratio at birth - in $\%$ males & 50 & \\
\hline Density-dependent reproduction & No & \\
\hline Dispersal & No & \\
\hline$\%$ Adult females breeding & 74 & (Bradley et al. 2000) \\
\hline Distribution of broods per year & 0,100 (both islands) & \\
\hline \multirow{2}{*}{ Distribution of offspring } & 0.531, SD 0.2; & \\
\hline & 0.478, SD 0.2 & \\
\hline$\%$ Mortality from age 0-1 & 42, SD 10 & (Newman et al. 2009b) \\
\hline$\%$ Mortality from age 1-2 & 14.7, SD 10 & (Scofield et al. 2001) \\
\hline$\%$ Annual mortality from age $2+$ & 4.8 & (Clucas et al. 2008) \\
\hline$\%$ Males in breeding pool & 100 & \\
\hline Initial population size & 2,$590 ; 88$ & See methods \& Chapter Three \\
\hline \multirow[t]{2}{*}{ Carrying capacity } & 9,$564 ; 550$ & \\
\hline & 1. None & \\
\hline \multirow[t]{2}{*}{ Harvest } & 2. Historic & \\
\hline & 3. Future & \\
\hline
\end{tabular}




\subsubsection{Environmental concordance of reproduction and survival}

VORTEX is able to incorporate variation in environmental conditions to influence reproduction and survival either independently or simultaneously on the species modelled. Oceanic and climatic anomalies have been found to have little relationship with reproductive output of the short-tailed shearwater (Bradley et al. 2000) or the survival of black petrels (Procellaria parkinsoni; Imber et al. 2003). However, environmental variation has been shown to have important impacts on reproduction in some seabirds (Weimerskirch et al. 2001) and influence survival rates in others (Barbraud \& Weimerskirch 2003; Jenouvrier et al. 2003). Fluctuations in chick production have been found to correlate with oceanic anomalies in a southern population of sooty shearwaters (Lyver et al. 1999). I therefore considered a good year for reproduction to be a good year for survival in VORTEX.

\subsubsection{Catastrophes}

Events such as food web perturbations, extreme weather events and predator invasion could have catastrophic effects on small, insular sooty shearwater populations in the Marlborough Sounds. The effects of such events are difficult to quantify and given the duration of this study, no effects were able to be measured. Similarly, no published estimates were found from which to infer the impact of a catastrophic event. I therefore excluded catastrophes from simulations.

\subsubsection{Breeding system}

Monogamy is the prevalent pair-bond in seabirds (Lack 1968). In sooty shearwaters on Whero Island, Richdale (1963) found pair-bonds lasted variable lengths of time. Of 83 pair-bonds recorded, $61 \%$ ended through loss of one of the pair and $16 \%$ through divorce. He recorded one pair with a bond lasting at least 11 years. Extra-pair fertilisations have been found to occur in the short-tailed shearwater (Austin \& Parkin 1996) but not in other species, for example Leach's storm-petrel (Oceanodroma leucorhoa; Mauck et al. 1995). In the absence of genetic analysis to provide evidence 
for an alternative breeding system in the sooty shearwater, I used long-term monogamy in VORTEX models.

\subsubsection{Age of first reproduction}

Age at which the first offspring are born is not known for the sooty shearwater. Richdale (1963) suggested breeding began at an average age of six years but suspected this age varied between individuals. In the closely related short-tailed shearwater the majority of young adults first breed between six and eight years of age (Bradley et al. 1989). Using data from the short-tailed shearwater, Newman et al. (2008; 2009b) constructed an age-structured population model to estimate age at first breeding in the sooty shearwater. Their mean age estimate was 7.9 years of age for both sexes. I rounded this to eight years for use in VORTEX models.

\subsubsection{Maximum age of reproduction}

The maximum age of reproduction is not known for the sooty shearwater. Sooty shearwaters could live for at least 40 years (G. Taylor pers comm.). The oldest age record of a short-tailed shearwater was a bird banded in 1960 and recovered dead 48.3

years later (ABBBS Database, Department of the Environment, Water, Heritage and the Arts, Australia). One study estimated sooty shearwater life expectancy by extrapolating an estimated adult survival rate from a hypothetical population until only $5 \%$ of the population remained. The result was a lifespan of 32 years (Hamilton \& Moller 1995). Conducting the same extrapolation with more recent data (the adult survival rate estimate of Clucas et al. (2008)) gives a life expectancy of 60 years. As VORTEX assumes life expectancy to equate to the maximum reproductive age, I used 40 years because it is a conservative compromise.

\subsubsection{Broods and progeny per brood}

Sooty shearwaters have one brood per year and lay one egg which is not replaced if it fails (Warham 1990). 


\subsubsection{Sex ratio}

There is no information available on the influence or importance of sex ratio in the sooty shearwater (see Chapter Three). I therefore assumed a 50:50 sex ratio.

\subsubsection{Density-dependence}

Density-dependence is suspected to occur in some sooty shearwater populations where rates of population decline have been faster in areas of relatively high initial burrow entrance density (Moller et al. 2009a). The low rates of burrow occupancy suggest that density-dependence may not currently affect breeding on Tītī and Motungārara (Chapter Three) but it could occur when the populations increase in density. I did not include density-dependence in any simulations to simplify analysis of model outputs. The occurrence of density-dependence is something that should be investigated in the future.

\subsubsection{Dispersal}

High levels of philopatry are not always the rule in seabirds (Coulson \& Coulson 2008). For example, natal recruits of short-tailed shearwaters on Fisher Island composed approximately $40 \%$ of the breeding population. It was estimated that around half the surviving young adults emigrated and an equivalent number of unbanded birds recruited into the Fisher Island breeding population (Serventy \& Curry 1984). In the sooty shearwater, dispersal of pre-breeding birds from their natal colony to other populations in New Zealand is likely to occur at high levels (G. Taylor pers comm.) though this level of mixing is currently unknown (Newman et al. 2009b). I chose to treat each island as a stand alone population for use as a baseline in lieu of any specific migratory information for these populations and to keep it simple for comparing the outputs from the model.

\subsubsection{Percentage of adult females breeding}

Adults of breeding age have been known to skip years between breeding in other Procellariiformes, for example the short-tailed shearwater (Wooller et al. 1990; Bradley 
et al. 2000), Cory's shearwater (Calonectris diomedea; Mougin et al. 1997), the southern fulmar (Fulmarus glacialoides; Jenouvrier et al. 2003), and possibly the northern fulmar (Fulmarus glacialis; Ollason \& Dunnet 1983). In lieu of any specific information for sooty shearwaters, I assumed intermittent breeding also occurred in this species. Therefore, to estimate the percentage of adult female sooty shearwaters breeding, I combined the data on absent and non-breeding female short-tailed shearwaters from Bradley et al. (2000).

\subsubsection{Distribution of broods per year}

The probability of a female having one brood was set to 100 because it was assumed that all copulations resulted in an egg and the probability of multiple broods was zero.

\subsubsection{Distribution of offspring per brood}

I used breeding success data as the distribution of the number of offspring produced from each brood. Breeding success rates calculated in Chapter Three were combined with six years of breeding success data recorded on Whenua Hou (Newman et al. 2009a). Native weka (Gallirallus australis) are known to hunt and kill young shearwater chicks (Brothers 1984; Harper 2006) and are present on Motungārara Island. Following findings from Harper (2007), I increased the mortality on Motungārara by $9.9 \%$ to account for weka predation.

\subsubsection{Mortality rates}

First year rates of mortality on each island were defined as the time of fledging to age one. Mortality rates were averaged from Newman et al. (2009b) resulting in a rate of $42 \%$ which is comparable with $44 \%$ in common guillemots (Uria aalge; Harris et al. 2007) and 48\% in Cory's shearwater (Jenouvrier et al. 2008). This estimate also closely matches that calculated from short-tailed shearwater data to model sooty shearwater populations (Hunter \& Caswell 2005). Uncertainty was set at 10\% (Jones 2002).

The juvenile mortality rate calculated by Newman et al. (2009b) assumed constant mortality for the first two years. When first year mortality was also used in the second 
year, both populations crashed. This clearly does not reflect reality because the populations have likely survived on these islands for hundreds of years. Survival rates increase with age in many other seabirds. In the common guillemot, second year survival increased from 56 to $79.2 \%$ (Harris et al. 2007) and from $52 \%$ in first year birds to $88 \%$ in Cory's shearwater pre-breeders (Jenouvrier et al. 2008). I used non-breeder survival of $85.3 \%$ calculated by Scofield et al. (2001) for second year survival as it aligned closely with survival estimates from other seabird studies, including a sooty shearwater model developed by Hunter and Caswell (2005). I used the standard deviation from first year survival to incorporate uncertainty in the data.

It is likely that sooty shearwater survival rates become similar to that of adults from when young birds first return to the breeding grounds (Richdale 1963). Sooty shearwaters return to their natal colonies from the age of two as pre-breeders or transients (Clucas et al. 2008). I applied inverse adult survival rates developed by Clucas et al. (2008) to all birds aged two and above for mortality rates in VORTEX models.

\subsubsection{Mate monopolisation}

The percentage of adult males that makes up the pool of available breeders was assumed to be $100 \%$. While it is likely that not all males breed in a given year, this number is expected to be limited by the percentage of adult females breeding.

\subsubsection{Initial population size}

I defined the population size as the number of breeding adults in each population. I assumed that the number of eggs laid on each island represented the total number of breeding pairs and therefore doubled the number of eggs to account for breeding adults. I undertook three trips to Motungārara in January, March and April 2009 to obtain a census of breeding burrows. The total came to 44. On Tîtī Island I calculated the total number of potentially occupied burrows (see Chapter Three) and used this as a proxy for breeding pairs. 


\subsubsection{Carrying capacity}

Burrowing seabirds are spatially limited by suitable burrowing habitat. I determined the potential carrying capacity of Titī Island using the average burrow density within ten 10 $x 10 \mathrm{~m}$ quadrats $\left(0.139\right.$ burrows per $\left.\mathrm{m}^{2}\right)$. I then determined the number of burrows occupied by sooty shearwaters (SSB) as:

$$
S S B=B D * A * P S
$$

Where BD is the burrow density, $A$ is the total area of the colonies (obtained from Baker et al. (2009)), and PS is the proportion of burrows in the $10 \times 10 \mathrm{~m}$ plots occupied by sooty shearwaters, including empty burrows to incorporate a maximum potential occupancy rate. The resulting number of burrows was taken to represent breeding pairs for the island and doubled to estimate the total number of breeding birds and therefore carrying capacity of the island.

The carrying capacity of Motungārara Island was determined by first gaining an estimate of burrow density from Long Island. Using a tape measure, I measured two areas (108 and $\left.188 \mathrm{~m}^{2}\right)$ and counted all the burrows within them ( 0.138 burrows per $\mathrm{m}^{2}$ ). I then calculated the proportion occupied by sooty shearwaters and added it to the number of empty burrows to obtain the maximum potential occupancy rate. The total area of suitable habitat on Motungārara was obtained using polygons on Arc GIS version 9.3. Based on my familiarity with Titī and Long Island burrowing habitat, I defined suitable habitat as areas with taupata and ngaio dominant in the canopy cover, and where soil and slope were suitable for burrowing which I determined during field trips to the island. I then used the formula used for calculating carrying capacity on Titī Island.

\subsubsection{Harvest}

Traditional harvest of sooty shearwaters on Titī Island was stopped in 1960 (Gaze 2000) and on Motungārara in 1963 (Douglas 1963). Models were initially run without harvesting. Then, two further harvesting scenarios were modelled for Motungārara and Titī respectively. Harvest data were obtained from two iwi groups (Chapter Two) and 
historic archives. I assumed the biological parameters (and their associated uncertainty) have not changed over the last 180 years.

To investigate effects of historic harvesting levels on Motungārara I assumed the population was initially at carrying capacity. Harvest began at the time Te Atiawa arrived in Queen Charlotte Sound around 1829 (Chapter Two; Mitchell \& Mitchell 2004) and continued until 1963 when it legally stopped (Douglas 1963). I modelled a harvest of 30 birds taken every two years (Chapter Two). As a comparison, I also ran a simulation of the harvest continuing until 2009 to account for any poaching that may have happened since 1963.

To investigate effects of historic harvesting levels for Titī Island the population was assumed to be at carrying capacity when the Crown purchased the island in 1856. Due to my lack of historic data prior to 1856, I ran harvest simulations beginning in 1856 taking 200 birds every two years until 1960 (Chapter Two). As for Motungārara, I also ran a simulation in which harvesting continued until 2009. Poaching was known to occur in the 1970s (Chapter Two), and there is evidence of continued illegal harvest into the 1990s (Gaze 2000). An archive (Bell 1955b) mentioned historic harvest levels of 1000 birds but did not specify exactly how long ago this occurred or its regularity. To test the impact of the higher levels of historic harvest, I ran a scenario starting at carrying capacity that examined the effect of taking 1000 birds every four years from 1856.

In addition, I investigated the effects contemporary harvesting would have upon the current populations. Sooty shearwater generation times are not present in the published literature but outputs from VORTEX, given the input parameters I used, suggest a generation time of approximately 19 years. I therefore investigated harvesting effects over 100, 150 and 200 year timeframes to incorporate approximately five, eight and ten generation times respectively. The mātauranga Māori (from Chapter Two) indicated that harvest would likely occur to preserve culture rather than to emulate historic harvest levels. I therefore tested different low-level harvest scenarios. For Motungārara I tested the harvest of one to ten birds biennially. I followed a similar 
pattern for Titī but increased the harvest size to simulate taking birds in multiples of ten, from ten through to one hundred birds biennially.

\subsubsection{Sensitivity analysis}

Biological parameters were adjusted by $\pm 10 \%$ to determine their relative importance for population persistence. The impact of each parameter on the population growth rate is reported.

\subsection{Results}

The results of model simulations and harvesting scenarios are presented. All results are presented \pm one standard deviation.

\subsubsection{No harvest}

Using the model parameters summarised in Table 4.1, the population growth rate was slightly negative for the Motungārara population ( $r=-0.001 \pm 0.05$; Fig. 4.1a) but positive for the Titī population ( $r=0.01 \pm 0.04$; Fig. 4.1b). The population size increased by $164 \pm 15 \%$ on Titī and remained virtually unchanged on Motungārara. Both island populations had a zero probability of extinction over 100 years.
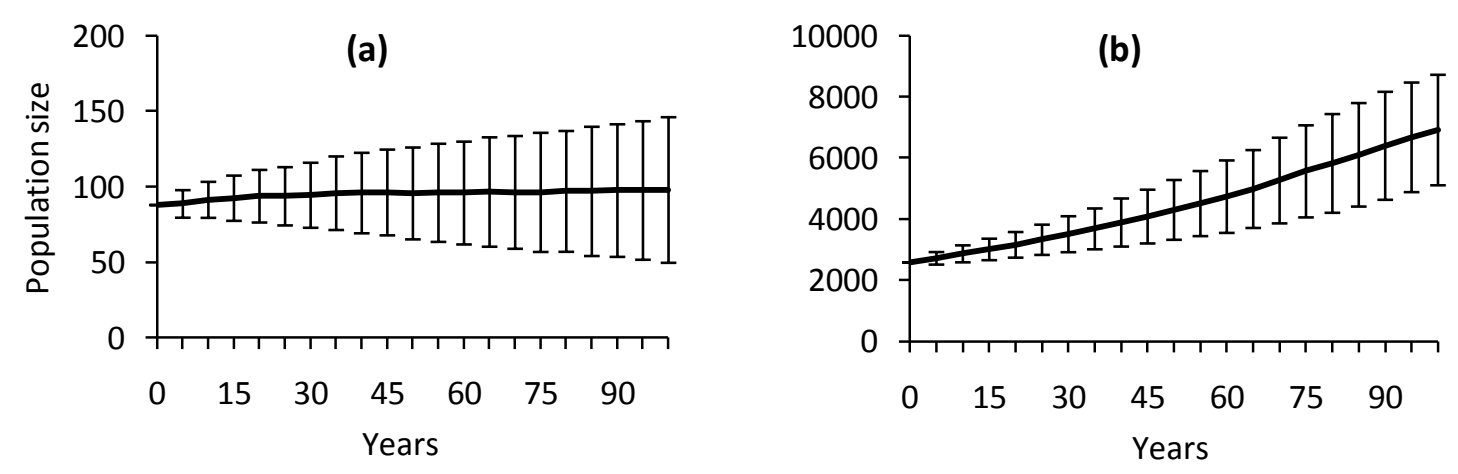

Figure 4.1: Population trajectories for Motungārara (a) and Titī Island (b) without harvest. Both populations had $100 \%$ probability of survival over 100 years. Population size is represented on both y axes. Error bars represent standard deviations. 


\subsubsection{Historic harvest}

Population size matched very closely with the observed number of breeding adults on Motungārara Island in 2009 under the assumption that poaching continued after 1963 with a similar frequency and intensity to historic legal harvest levels (Table 4.1; Fig. 4.2a). Had harvest ceased in 1963, the trajectory suggests the population could have been larger, but still only $29 \pm 17 \%$ of the population at carrying capacity.

On Titī, the population remained near carrying capacity even when it was assumed harvest occurred following the island's closure (Fig. 4.2b). However, the intrinsic growth rate $(r)$ declined to $-0.012 \pm 0.041$ in years when harvest occurred. Continued harvest until present day would have reduced the population but not to as low a level as the current population estimate (Chapter Two). Taking 1000 birds every four years saw a rapid population decline. However, the rate of decline slowed when the population dropped below the level at which 1000 birds could be removed.

\subsubsection{Potential future harvest}

Given current population parameters, the impact of taking low numbers of chicks from Motungārara varied greatly depending on the time frame examined (Fig. 4.3). For example, if two birds are taken every two years the population's survival decreases from $93 \%$ over 100 years to $49 \%$ in 150 years to $16 \%$ over 200 years. The difference in population survival between the 100 and 150 to 200 year time frames varied between two and sixty-six percent depending on the number of chicks harvested. For the population to have a greater than $50 \%$ chance of persisting over 200 years, no more than one chick every other year could be taken.

On Titi Island, the population could sustain a much larger harvest, but the implications for the relatively short-term (100 years) were underestimated when compared with the long-term impacts (150 and 200 years) of harvest. The population growth rates were remarkably similar for each 100, 150 and 200 year time frame until the unsustainable harvest threshold (of over 60 birds) was breached (Fig. 4.4). However, only when 100 
birds were taken biennially for 200 years did the probability of extinction increase from zero to 0.006 (data not shown).
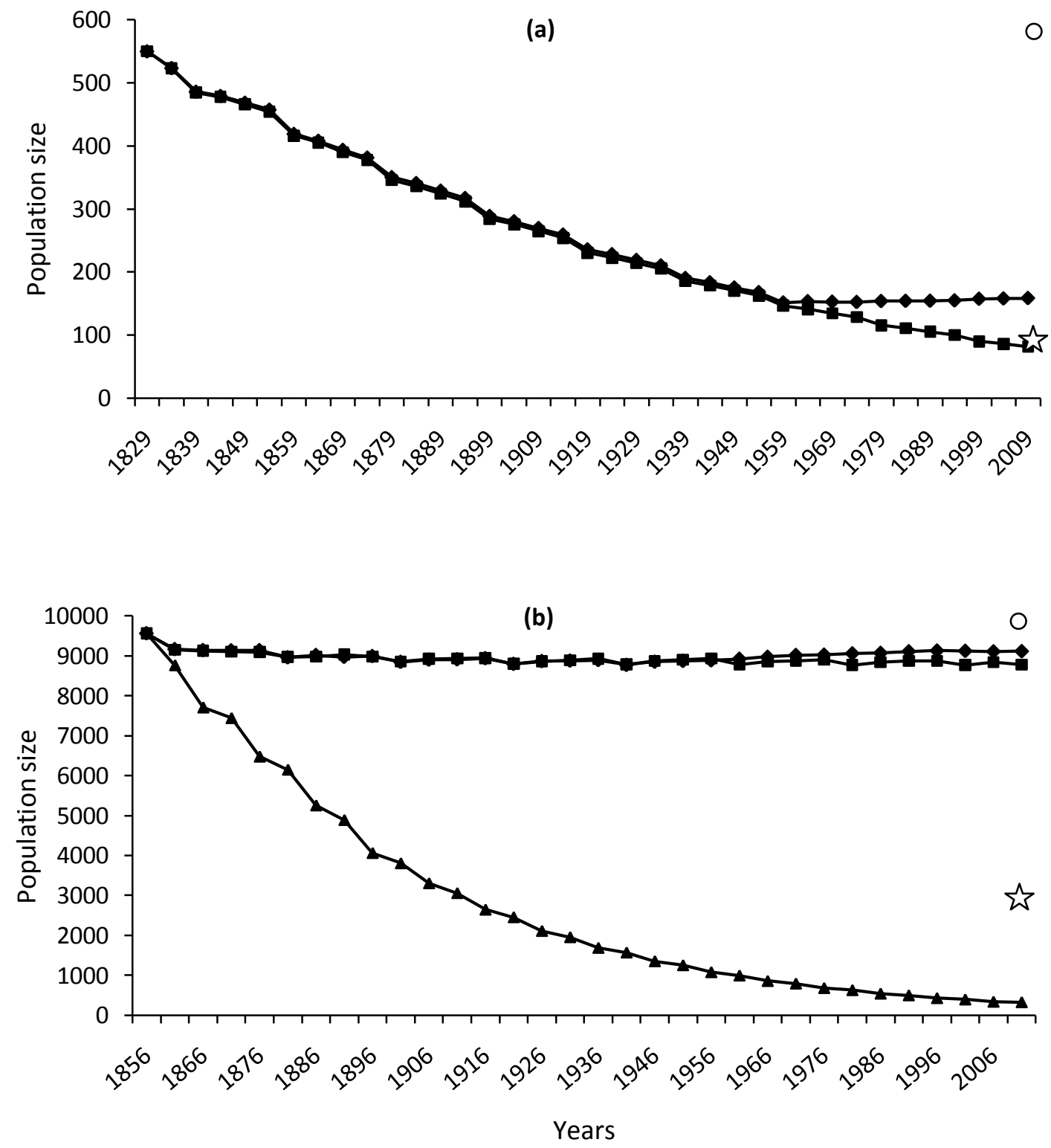

Figure 4.2: Population trajectories of Motungārara (a) and Titī (b) using historic harvest estimates. For both populations, cessation of harvest in the 1960s is represented by diamonds and continued harvest shown with squares. On Titī, the harvest of 1000 birds every four years is shown with triangles. On both graphs, open circles represent carrying capacity and open stars represent the population size estimated for each island in 2009. 


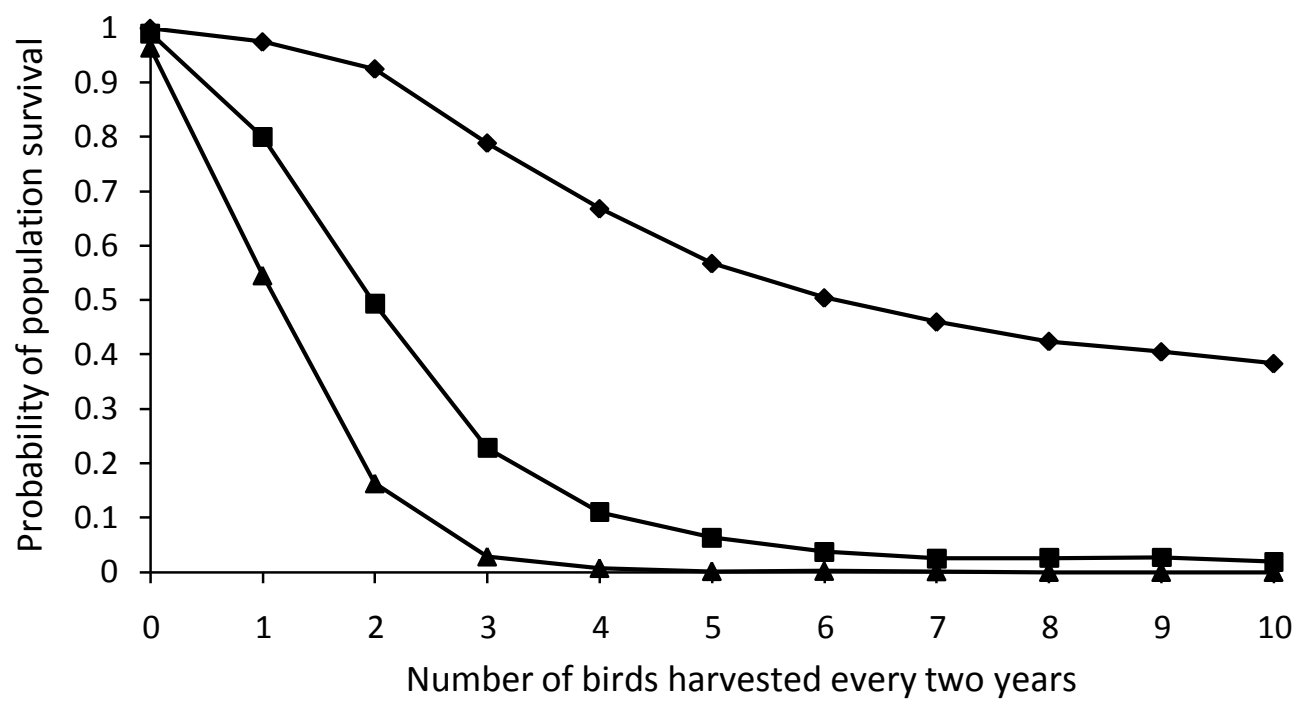

Figure 4.3: The projected impact of harvest for Motungārara Island given its current population size and dynamics. Diamonds represent the trajectory over 100 years; squares over 150 years and triangles over 200 years.

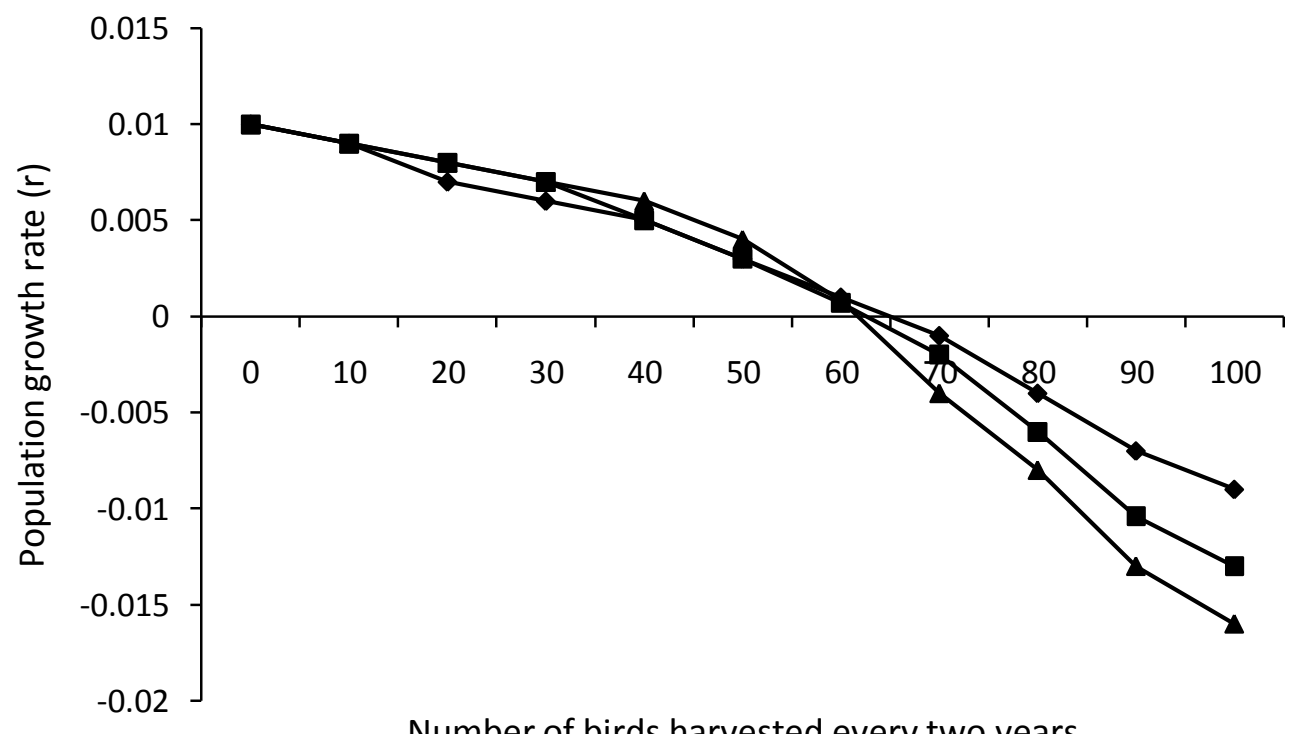

Number of birds harvested every two years

Figure 4.4: The projected population growth rates of the Titī Island population with varying levels of harvest over 100 (diamonds); 150 (squares) and 200 (triangles) years. Harvest impact was modelled on the current population size and biological parameters estimated for the island. 


\subsubsection{Sensitivity analysis}

The population growth rate on Motungārara was most sensitive to an increase in breeding success, first year mortality, age at first breeding and adult mortality (presented in order of sensitivity; Table 4.2). For example, increasing breeding success by $10 \%$ improved $r$ by $0.6 \%$ whereas increased adult mortality lowered $r$ by $0.3 \%$.

On Titī, the population growth rate was most sensitive to (in order of sensitivity) an increase in breeding success, age at first breeding, first year mortality and adult mortality (Table 4.2).

Table 4.2: Results of sensitivity analysis on the population growth rate modelled in VORTEX. Growth rates ( $r$ ) presented are the result of a $10 \%$ change in parameter estimates. Stochastic variables were not changed.

\begin{tabular}{lcccc}
\hline & \multicolumn{2}{c}{ Motungārara Island } & \multicolumn{2}{c}{ Titī Island } \\
\cline { 2 - 5 } Model value & \multicolumn{2}{c}{-0.001} & \multicolumn{2}{c}{0.01} \\
\hline Parameter & $\begin{array}{c}10 \% \\
\text { increase }\end{array}$ & $\begin{array}{c}10 \% \\
\text { decrease }\end{array}$ & $\begin{array}{c}10 \% \\
\text { increase }\end{array}$ & $\begin{array}{c}10 \% \\
\text { decrease }\end{array}$ \\
\hline Breeding success & 0.005 & -0.007 & 0.015 & 0.004 \\
Adult mortality & -0.004 & 0.003 & 0.007 & 0.013 \\
First year mortality & -0.005 & 0.004 & 0.006 & 0.013 \\
Second year mortality & -0.002 & 0 & 0.009 & 0.011 \\
\cline { 2 - 5 } & $\mathbf{1}$ year & $\mathbf{1}$ year & $\mathbf{1}$ year & $\mathbf{1}$ year \\
& more & less & more & less \\
\cline { 2 - 5 } Age at first breeding & -0.005 & 0.004 & 0.006 & 0.014 \\
Maximum age of reproduction & 0 & -0.002 & 0.01 & 0.009 \\
\hline
\end{tabular}

\subsection{Discussion}

The results of the population viability analysis suggest that (a) Motungārara has a low negative population growth rate and on Titī this is low but positive; (b) historic levels of exploitation were unlikely to have been sustainable on Motungārara even with the 
population at carrying capacity and it is likely that historic harvest levels have influenced the current condition of the population that persists on Titī, and; (c) given the current population parameters, it is unlikely Motungārara can sustain any level of harvest in the near future but low-level harvest could potentially be undertaken on Titī.

\subsubsection{Population growth rates}

Rates of population increase for Motungārara (-0.1\%) and Tîtī Island (1\%) are very low which is not uncommon in many seabird species. However, this scenario did not incorporate immigration or emigration or any catastrophic events that may influence the populations' growth and survival. Gaze (2000) found no change in burrow occupancy rates on Titī Island between 1987 and 1998 and suggested the population's distant position from the centre of the species' breeding range meant recovery following rat eradication was slow. Jones (2002) estimated a growth rate of $4.4 \%$ for mainland sooty shearwater colonies under intensive predator control; the location of these colonies closer to the breeding centre may lend support to Gaze's recovery hypothesis (Gaze 2000). However, a periodic stage-structured matrix model for sooty shearwaters developed by Hunter and Caswell (2005) produced a growth rate of $-1.5 \%$ in the absence of harvest. Even in optimal conditions, Dillingham and Fletcher (2008) suggested albatross and petrel or shearwater populations could not exceed $7 \%$ and $10 \%$ growth per annum respectively. Regardless, the growth rates observed on Motungārara and Tîtī are similar to those of other seabird species. For example, the black-browed albatross on Kerguelen Island has a stochastic growth rate of $0.8 \%$ but the authors suggested the population was limited by fisheries bycatch (Rolland et al. 2009). Similarly, the Amsterdam albatross has an estimated annual rate of growth of $4 \%$ and the wandering albatross is similarly positive following declines attributed to fishing in the 1960s and 70s (Weimerskirch et al. 1997).

\subsubsection{Historic harvest impacts}

The size of the current population on Motungārara could be directly related to historic levels of exploitation experienced on the island (Fig. 4.2a). Given the threats facing the 
wider sooty shearwater population, for example the increased intensity of extrinsic events such as climate anomalies (Lyver et al. 1999) and fisheries related mortality (Uhlmann et al. 2005), it is likely that the localised impact of harvest on Motungārara has been exacerbated by such additional external threats. However, the long history of Māori occupation of the Marlborough Sounds (Mitchell \& Mitchell 2004) suggests seabird exploitation on Motungārara likely occurred long before the arrival of Te Atiawa to Queen Charlotte Sound. The continued persistence of the Motungārara population suggests that although the pressures facing the population have been prolonged, the population is resilient to change, although the limits to its resilience are as yet unknown.

The dramatic decline in population size on Titī Island when taking 1000 birds every four years, suggests that the population could not have withstood that level of harvest for sustained lengths of time. Once harvesters realised this, it is possible that they then adjusted the harvest size accordingly. For example, the harvesting rates provided by Ngāti Kuia harvesters (Chapter Two) may reflect the level of resilience of the population to harvest, at that time. If thousands of birds had been taken in the past, then the population was unlikely to be at carrying capacity in 1856 (as assumed in the historic harvest scenario; Fig. 4.2b). It is therefore difficult to quantify the impacts of the historic harvest rates proposed by iwi members as the size and condition of the population on Titī at the time are unknown.

The harvest history of the Marlborough Sounds has probably shaped the sooty shearwater populations on Motungārara and Titī Islands. The additional presence of weka on Motungārara and the historic presence of rats on Titī may have contributed to declines in productivity and burrow occupancy (Harper 2007). Motungārara was suggested to have the most resilient shearwater population in the Marlborough Sounds in the 1950s (Kelly 1960) but the small size of the island and the rate at which birds have been lost from the population have clearly outpaced the natural replenishment rate. In contrast, the population on Titī was not considered to be as rigorous due to the presence of rats (Kelly 1960). With the rats now removed it is possible that even with 
occasional illegal harvest, the population is in better condition now than it was at the time of harvest cessation. Moreover, a noteworthy implication from Figures $4.2 a$ and $b$ is that the populations would increase, albeit slowly, if all illegal harvesting was to stop. This gives hope for recovery of the populations, particularly that on Motungārara.

\subsubsection{Possible harvest rates}

Different potential harvest rates had quite different impacts on each population when modelled over 100, 150 and 200 years. Generation time may have an important influence when trying to understand population patterns (Sæther et al. 2005b). In species with long generation times, the risk of extinction may be underestimated if the wrong time frame is used (Armbruster et al. 1999). For example, a study of Asian elephants (Elephas maximus) revealed a 200 year time lag in population decline that had not been picked up in an earlier study that estimated population growth over a 100 year period (Armbruster et al. 1999). Sooty shearwaters can probably live for at least forty years; it is therefore likely that population trends are better detected over periods of time that incorporate a suitable number of generations (O'Grady et al. 2008). This was exemplified in Figure 4.3 which shows harvest impact over five, eight and ten generations (100, 150 and 200 years respectively) on Motungārara. For example, taking two birds every two years gave the population a $92.5 \%$ probability of survival over 100 years but this dropped to $16.3 \%$ over 200 years. On Titi the trend was similar but the larger size of its population buffered its probability of extinction. While only one harvesting scenario led to extinction on Tîtī (after removing 100 birds biennially for 200 years), the size of almost all populations declined dramatically when the threshold rate, of over 60 birds biennially, was exceeded. This has important management implications for the Titī population when setting harvest limits.

A criterion utilised by the IUCN to define a species as 'vulnerable,' is that the probability of survival must be greater than $90 \%$ within the next 100 years (IUCN 2001). This criterion provides a useful framework on which to assess the harvest threshold of species, as has been shown in a study of the Scandinavian brown bear (Ursus arctos) in 
Norway (Tufto et al. 1999). With no harvest, both the Titī and Motungārara Island populations have $100 \%$ probability of survival over the next 100 years (Figs. 4.1 a $\&$ b). On Motungārara, given the IUCN criterion, two birds could be taken biennially (Fig. 4.3). However, when tested over a longer timeframe, the impact of that level of harvest is shown to be of significant detriment to the population and no harvest is demonstrated to be the best option (Fig. 4.3). In contrast, on Titī Island, only when 100 birds were taken biennially over 200 years did the probability of extinction increase from zero to $0.6 \%$. However, when the level of harvest increased to over 60 birds, despite the probability of survival remaining high for all three timeframes tested, the population decreased substantially below the initial population size of 2,590 birds. These results have several implications. Firstly, that the IUCN criterion does not appropriately represent realistic timeframes for long-lived vertebrates with long generation times. I

suggest a criterion of a $<5 \%$ risk of extinction over 100 years is perhaps more appropriate. Secondly, should harvest limits be set for Titī Island, given the exposure of the population to threats outside the breeding season, more intensive monitoring (for example with the aid of a burrowscope) would be required to determine the long-term sensitivity of the population to the additional impact of harvest.

\subsubsection{Alternative harvest impacts}

Harvesting strategies described by the Te Atiawa and Ngāti Kuia harvesters could affect the dynamics of these small populations. Selective harvest of larger chicks (Chapter Two) may compromise the survival and recruitment probability into the Titī and Motungārara populations (Gaston 1997; Sagar \& Horning 1998; Hunter et al. 2000b). Admittedly, because the Motungārara population is so small, any harvest at all is likely to compromise the population. Nevertheless, the premise that sustainable wildlife harvest removes the 'doomed surplus' is unlikely to apply to small seabird populations because the 'surplus' in the case of sooty shearwaters, may actually be those chicks with the best chance of survival (Sagar \& Horning 1998). In addition, the implications for the fitness of a population sustained by the recruitment of what are essentially 
'runts' could have significant effects in the long-term, for example, as a result of reduced genetic fitness (Harris et al. 2002).

The extent to which seabirds can compensate for additional mortality is equivocal. Compensatory mechanisms would likely operate through density-dependence (Moller 2006). Increases in the occurrence of juveniles has been observed with the decline of adults through fisheries related mortality in the wandering albatross (Tuck et al. 2001). But the authors caution that the compensatory ability of the population should not be overstated. Similarly, Gaston (1997) hypothesised that ancient murrelets (Synthliboramphus antiquus) adjusted their breeding time to compromise between predation of adults and appropriate conditions in which to feed and rear their chicks. Given the more global timetable of the sooty shearwater due to its annual migration, the ability of the species to adjust its behaviour to compensate for periods of extensive predation, i.e. for the March/April harvesting season, is unlikely but would be worthy of investigation.

\subsubsection{Population persistence}

Despite all the pressures facing the populations, both the Titĩ and Motungārara populations continue to persist. Even with all agents of decline removed, these small populations would still be vulnerable to the sources of uncertainty that are intrinsic to the dynamics of small populations (Shaffer 1981). Sooty shearwaters, like all Procellariidae, are colonial breeders (Warham 1990), presumably attracted to the colonies through the vocalisations of other individuals as evidenced through the establishment of breeding populations of other Procellariidae species using electronic acoustic attraction (Miskelly \& Taylor 2004; Miskelly et al. 2009). The extent to which a population is large enough to attract additional birds is unknown but worth investigation. If, for example, the Motungārara population is no longer large enough to attract additional adults to the breeding population, this would further exacerbate the population's risk of extinction. An additional consideration associated with reduced migration would include the genetic implications of a reduced population size, the 
effects of which can cause significant problems for population persistence as witnessed in the kakapo (Jamieson et al. 2006).

Assuming vocal attraction is not an issue yet, persistence of the Motungārara and Titī populations may be the result of harvest impact being ameliorated by immigration to the islands by birds from unharvested refugia populations (Bragg et al. 2009; Moller et al. 2009a). However, the level of connectivity between islands is unknown and therefore the extent to which immigration alone could replenish depleted populations is uncertain. Immigration rates for different seabird species vary dramatically. For example, as described earlier on Fisher Island, it was estimated that around $50 \%$ of the breeding short-tailed shearwater population was made up of unbanded recruits (Serventy \& Curry 1984). In the wandering albatross, immigration rates differed between sexes with $24.4 \%$ of females and $12.5 \%$ of males not returning to breed on Possession Island in the south-western Indian Ocean (Weimerskirch et al. 1997). In a small marbled murrelet (Brachyramphus marmoratus) population, immigration was estimated at around $16 \%$, which was believed to be compensating for the low number of natal recruits being produced from the population (Peery et al. 2006). Jones (2002) found immigration to be an important influence during elasticity analyses he performed on his sooty shearwater population model. When set to zero, the growth rate became negative. Given the inability of VORTEX to allow immigration from external populations, I attempted to mimic immigration through supplementing the population with $5 \%$ of the adult population annually on Motungārara (note: data not presented, this scenario was tested purely as a pilot investigation on which to speculate the potential importance of immigration on the population). The result raised the population growth rate and identifies a critical area of research needed to determine its importance in mitigating harvest intensity.

To extend the immigration idea further, the extent to which the islands in the Marlborough Sounds region are acting as a meta-population is also an important unknown variable. The long term study of the short-tailed shearwater revealed that birds dispersing from Fisher Island were commonly found in colonies close to and 
facing Fisher Island (Serventy \& Curry 1984). A similar pattern of dispersal has been found in the northern fulmar (Burg et al. 2003). This suggests that when dispersal occurs, the degree of movement may be quite localised. Sooty shearwater populations occur on an additional twelve islands in the Marlborough region but their population sizes range from tens to a few hundred breeding pairs (Newman et al. 2009b). If only a small proportion of the breeding population is made up of natal recruits, then a large meta-population may exist. If this is the case, because of its large size in relation to nearby populations, Titī is probably acting as a sink and a large number of immigrants would be required to offset any population decline (Peery et al. 2006). This has important implications for those smaller Marlborough Sounds populations because additional harvest pressure may exacerbate declines in the populations that contribute immigrants to the larger population on Titī. If this is the case, then monitoring should not only occur on Titī Island but on nearby islands in the Marlborough Sounds where sooty shearwater populations occur. In addition, given the size of nearby populations, immigrants could be coming from source populations further afield, implicating a possible national meta-population but this would need genetic analysis (as has been done in the northern fulmar, Burg et al. 2003) for verification.

The typically low maximum annual growth rates in seabirds limit their ability to sustain high levels of additional mortality and recover quickly from depletion (Dillingham \& Fletcher 2008). Even if population parameters collected from the islands in the Marlborough Sounds have been underestimated (see Chapter Three), the clearly depleted state of the present Motungārara population suggests that the compounding effects of poaching, weka predation and extrinsic variables have exceeded the natural replenishment rate of the population. However, a lag effect as a result of their long life spans may be occurring. For example, Moller (2006) suggests that trends observed over a short period may have been determined by the ecological events that occurred in the several decades prior to when the trend was observed. A maximum harvest rate of $0.5 \%$ of the population has been suggested for threatened or depleted Procellariiform seabirds (Dillingham \& Fletcher 2008). During the 2008/09 breeding season only 17 
chicks fledged off Motungārara, demonstrating the low capacity of the population for harvest and reinforcing the viability analyses (Fig. 4.2). In contrast, the total population on Titī is in the order of 6,300 birds (Chapter Three), giving a maximum annual harvest of around 32 chicks if Dillingham and Fletcher's harvest rate is to be used. This number is within the potentially sustainable harvest rates determined by VORTEX (Fig. 4.4) and is potentially feasible as a total harvest size, provided the population size is not subject to unforeseen stochastic events that may compromise sustainability.

\subsubsection{Uncertainty and model interpretation}

A sensitivity analysis revealed that both the Motungārara and Titī populations were influenced most by changes in breeding success. This contrasts with a similar study that estimated the importance of predator control on mainland sooty shearwater populations using VORTEX (Hamilton \& Moller 1995). Their research found the sooty shearwater populations were most sensitive to a change in age at first breeding. This is perhaps not surprising given that the authors estimated life expectancy to be 32 years. Given the low fecundity of the species, lower breeding age would considerably increase the reproductive output and therefore growth rate of the population. Another sooty shearwater study found that changes in adult mortality had a far stronger impact on the population growth rate than did chick harvest rates (Hunter \& Caswell 2005). The sensitivity of Motungārara and Titī populations to changes in breeding success could be interpreted as a sensitivity to harvest because harvest would lower the productivity (i.e. the breeding success) of each population. This is an interesting contrast to the findings of Hunter and Caswell (2005). The small size of both the Titī and Motungārara populations compared to their more southern counterparts, where single island populations can consist of millions of individuals (Newman et al. 2009b), may be contributing to this result because of their greater sensitivity to demographic stochasticity (Shaffer 1981; Caughley 1994). Significantly, breeding success is one of the few seabird biological parameters that could be manipulated with relative ease. For example, the removal of weka or use of exclusion plots on Motungārara could increase 
the population's productivity (Harper 2007). Or supplementary feeding of chicks, pioneered for seabird translocations (Miskelly et al. 2009), may improve their probability of return by creating high fledging weights (Sagar \& Horning 1998). This could be an important opportunity for Te Atiawa at least, to be involved with the recovery of the populations.

The degree of uncertainty in parameter inputs is important for the reliability of population modelling (Brook 2000; Hunter et al. 2000a). Using parameters estimated over a long period would be expected to incorporate any environmental stochasticity that occurred over the time frame measured. The majority of the input parameters I used in VORTEX were from the published literature, of which the shortest study incorporated data from a six year period. However, I did not incorporate catastrophic events, as there are no data on their effects. Given the size of the island, a catastrophic event such as a large rain storm has the potential to flood a large percentage of the total burrows in one breeding season on Motungārara. Burrow inundation is not an abnormal phenomenon for burrowing seabirds, for example Providence petrels suffer high losses as a direct result of burrow flooding on Lord Howe Island (Bester et al. 2007). The long-term effects of flooding events and/or their regularity in the Marlborough Sounds however, are unknown. Catastrophic events at sea could also affect adult survival of small populations. For example, the occurrence of a tsunami or abnormal oceanic event may reduce their food source and cause the death of adults from starvation or exhaustion. Research into the impacts of catastrophic events such as the flooding of burrows or marine food shortages on the Marlborough Sounds sooty shearwater populations would assist in improving the output of the model parameters. Parameter estimation is always going to be difficult with only one season to collect data. For example, breeding success can be highly variable in seabirds. A 27 year study on the snow petrel (Pagodroma nivea) found average breeding success to be $51.3 \pm$ $16.3 \%$ but this ranged between $21-80 \%$ over the study period (Chastel et al. 1993). The recent abundance of published literature resulting from the large study of sooty shearwaters conducted by Otago University scientists is an enormous resource for this 
project and similar studies. Nonetheless, some parameters remain difficult to obtain. For example, in a highly mobile species like the sooty shearwater the low detectability of juvenile and pre-breeding birds makes estimation of their survival difficult. Many studies caution the interpretation of PVA when uncertainty and variability in the data are high (Brook \& Kikkawa 1998; Coulson et al. 2001) but concede its importance as a conservation tool given the absence of alternatives (Brook et al. 2002a). While the results of this study are by no means certain, they provide a useful starting point from which conservation managers and iwi can decide to prioritise further research and resources and evaluate requests to harvest.

\subsubsection{Conclusion}

This study has revealed a number of important parameters worthy of monitoring and research that should be conducted if low level harvests are to resume. Monitoring of population trends on Motungārara is urgently needed to determine whether the population is decreasing as suggested in this study. Research into levels of immigration and emigration is also important as it may be an important component of harvest mitigation. In the future, a model should be developed that can allow for dispersal from additional sources and proportional rates of harvest. The larger size of the Tîti Island population buffers it from harvest impacts. Regardless, if harvesting on Titī is to resume, harvest rates much lower than past levels need to be implemented if the population is to persist long-term. 


\section{A framework for harvest decision making: thesis summary and implications}

\subsection{Introduction}

This thesis represents the first substantive study of sooty shearwater (Puffinus griseus) populations in the Marlborough Sounds or indeed outside the centre of the species' breeding range. The integration and synthesis of mātauranga Māori (Māori traditional knowledge), scientific research and population modelling have provided insights into the development of a sustainable level of sooty shearwater harvest. The benefits of this synthesis mean conservation managers and iwi (Māori tribes) will have a greater understanding of the issues surrounding harvest for improved decision making. This would not have been possible using each method in isolation. I have provided information on the traditional harvest practices undertaken by local Māori and its implications for population persistence. I have also gathered location-specific life history traits of the species. I then combined the knowledge gained from these two studies and conducted a population viability analysis (PVA). This thesis provides new information on the cultural importance, biology and resilience of the species in the small populations in which it occurs in the Marlborough Sounds. It also provides a baseline from which to monitor the populations in the future.

\subsection{Summary of findings}

Although the mātauranga Māori of Ngā Takiwā and Ngāti Kuia in Chapter Two did not provide novel biological information for the Marlborough Sounds sooty shearwater populations, it did provide important information on the historic condition of the islands and their seabird populations, and allowed for specific harvest parameters to be tested in a PVA. The harvesters interviewed had novel muttonbirding techniques 
compared to the methods of Hauraki Māori grey-faced petrel harvesters (Lyver et al. 2008a), and also with sooty shearwater harvesters on the Titī Islands off Rakiura/Stewart Island (Kitson \& Moller 2008). Contact with the islands and the birds through harvest and involvement in monitoring were identified as important ways for the iwi to maintain a connection with the islands' environment and pass on mātauranga Māori to the younger generations.

The biological study of the Long and Titî Island sooty shearwater populations in Chapter Three presented biological data from two previously unstudied populations. The breeding chronology is similar to that of other sooty shearwater populations occurring at much higher latitudes in New Zealand. The results provide baseline data on which to monitor future population trends and provided important parameters for use in the PVA.

The results from the PVA in Chapter Four indicated that the population on Motungārara has a low, negative rate of population increase whereas on Titī Island, which has a population size over $2800 \%$ larger than Motungārara, the mean growth rate is still low at $1 \%$. From an historical perspective, the modelling suggested that past levels of harvest would have significantly depleted the populations. This analysis gives useful insights into the effect of harvest at various levels of intensity given the current state of the populations. Generally speaking, the Titî Island population may be able to withstand regular low-level harvest (but only tens of birds rather than hundreds) but it is unlikely that the population on Motungārara is in any shape to withstand harvest of any kind at this time.

\subsection{A framework for wildlife harvest decision making}

Decision making can be informed by science but it is ultimately a social and political decision (Ludwig et al. 1993). The view that human behaviour should be allowed to continue until evidence of its impact is procured, can polarise the generally precautionary approach used by many decision makers (Slooten et al. 2000). Use of a structured decision making process is highly beneficial in cases where there are 
contrasting opinions as to how a situation should proceed. I have used the results of my thesis to illustrate how a basic framework can be built to assist the decision making of conservation managers and iwi with regard to harvest (Fig. 5.1).

\subsubsection{The importance of communication and consultation}

Essential to the decision making process is the communication of ideas and consultation with stakeholder groups. Engagement with local communities is an important component of successful conservation projects (Ramstad et al. 2009). For example, when the animal harvested is of commercial value, it is important to ensure the community is engaged in the project and agrees with its approach in order to reduce poaching.

In the case of my thesis, both iwi and conservation managers have expressed a common goal of ensuring the persistence of sooty shearwater populations. The involvement of iwi in this research has been used to provide a more holistic picture of population viability for conservation and will enhance the uptake of decisions made. The approach I have taken can be used for any taonga (treasured) species with which Māori (or any other indigenous community) have a direct relationship and/or involvement in management.

\subsubsection{Evaluation of population size}

Before a population can be harvested its size needs to be determined. Small populations are much more susceptible to environmental and demographic stochasticity (Shaffer 1981; Lacy 1993; Caughley 1994) which may be exacerbated by additional harvest pressure.

The populations on the Tîtī, Motungārara and Long Island populations are small and at increased risk from factors such as fisheries bycatch or anthropogenic climate change in addition to any harvest. This in itself has important implications for management. For example, while conducting my fieldwork on Long Island, at least one (and possibly another two) fledglings were killed by a raptor. Despite these being natural predation 


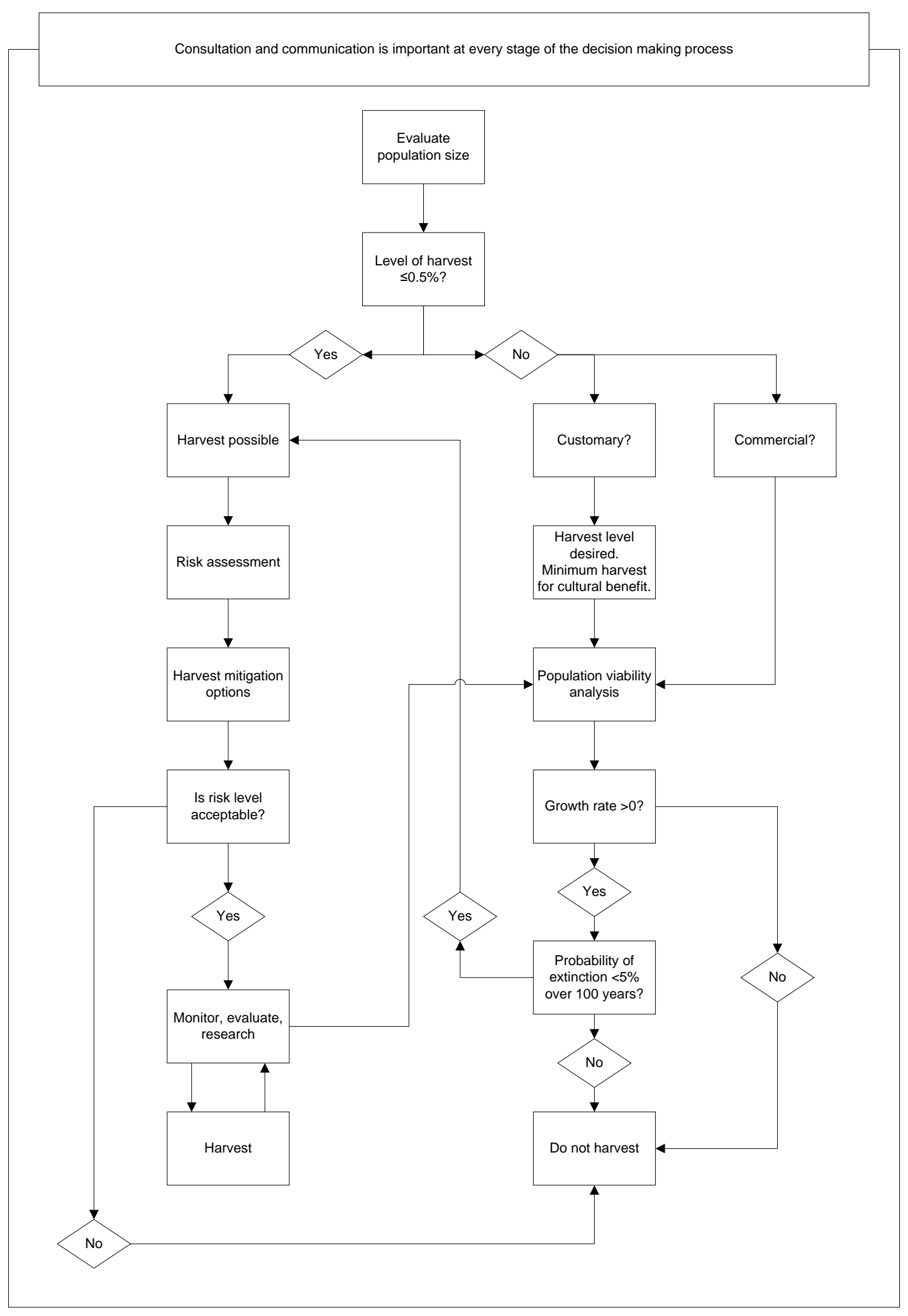

Figure 5.1: Decision making framework developed for conservation managers and iwi to evaluate requests to harvest wildlife. 
events, when a total of only 32 chicks fledged off the island in 2009 , the loss of three birds represents a significant proportion of the chicks available to fledge. In addition, an archive from 1960 suggested Motungārara once had the most resilient sooty shearwater population in the Marlborough Sounds (Kelly 1960). However, my research confirms that in 2009 the population was small, increasing its risk to stochastic processes. In this case, research and restoration management is required before the population can be re-evaluated for harvest consideration.

\subsubsection{The scale of harvest desired}

The scale of harvest is critical to its long-term sustainability. In addition, the harvest must be undertaken within the capacity of the species and/or the size of the population. For small or threatened seabird populations, a threshold of $0.5 \%$ or less can generally be regarded as sustainable (Dillingham \& Fletcher 2008). Any form of harvest beyond this threshold therefore requires greater analysis.

A commercial harvest generally aims to harvest the maximum number of animals possible. When done well, commercial harvest can be sustainable, for example, improved stock management of Pacific salmon (Oncorhynchus spp.) has provided record yields for Alaska and British Columbia (Ludwig et al. 1993). The goal of commercial harvest should be to maximise yields while maintaining a positive growth trajectory and ensuring the risk of extinction is low.

In contrast, optimal levels of customary harvest are guided by traditional ecological knowledge (Johannes 1982; Lyver 2002; Berkes 2008). Scale of harvest can range from hundreds of thousands (Moller et al. 2009a; Newman et al. 2009b) to tens (Lyver et al. 2008a) of animals harvested annually. It is important to determine the desired level of harvest and the minimum level of harvest required to provide a cultural benefit. The optimal harvest level will be between these two values. Consultation and communication is therefore critical at this stage to understand the perspective of those desiring customary harvest. In my study, the desired level of resumed harvest would 
likely match the minimum level required to maintain a cultural benefit, in the order of tens of birds rather than hundreds.

\subsubsection{Determining harvest sustainability}

Once a population has been deemed suitable for further investigation into whether its harvest is feasible, a number of factors need to be considered. Will the population decline once harvested? If harvest resumes, does the population have a greater than $5 \%$ risk of extinction over 100 years? (See Chapter Four). These questions can be addressed using a modelling approach such as population viability analysis. These tools can incorporate factors such as the presence of introduced predators or the possibility of a catastrophic event.

While the results of any model should be interpreted cautiously (Brook et al. 2002a), given the results of Chapter Four, it is unlikely harvest is able to be resumed on Motungārara Island. Harvest is more feasible for Titī Island, which is likely a result of its larger population size. Provided conditions do not deteriorate, the population could sustain a maximum biennial harvest of 60 birds although a number half this size would perhaps be more appropriate using a precautionary approach (Chapter Four). Though

my PVA could be improved by incorporating immigration (Jones 2002) and the effect of additional mortality from catastrophic events (Lande 1993; Vargas et al. 2007), its findings align closely to previous field studies (Gaze 2000).

It is important to have ongoing assessment of harvesting effects on population dynamics. The power of using a modelling approach which is repeatable is that new information can be incorporated over time.

\subsubsection{An assessment of the risks}

If a population is deemed resilient to harvest, the benefits and risks of harvest still need to be explored. The study species itself may be able to be harvested sustainably but it is still important to determine any flow on effects which harvest may create. For example, although sooty shearwaters are the primary target of harvest on both Motungārara and 
Titī Islands, there is the risk of harvesters taking flesh-footed shearwaters (Puffinus carneipes) on Titī Island. Speculation that Ngāti Kuia harvesters once targeted this species (Bell 1955b) raised concerns regarding the impact on the flesh-footed shearwater population and contributed to the cessation of harvest (Gaze 2000). The flesh-footed shearwater is heavily affected by fishing-related mortality and is declining on some islands (Baker \& Wise 2005; Priddel et al. 2006). The total New Zealand population is not thought to exceed 8-10,000 pairs (Baker et al. 2009). In 2009, the Titī Island flesh-footed shearwater population was estimated to be in the order of several hundred birds (Baker et al. 2009). I found these animals scattered throughout the island rather than in separate colonial areas at a 1:5 ratio of flesh-footed to sooty shearwaters. There is considerable risk that flesh-footed shearwaters could be mistakenly harvested which would likely tip the population into decline (similar to the harvest scenarios for sooty shearwaters on Motungārara in Chapter Four). Therefore, any harvest considerations on Tîtī Island must account for the presence of flesh-footed shearwaters.

\subsubsection{Can harvest impacts be mitigated?}

Identification of modes through which harvest impacts can be mitigated is an important component of the risk analysis process. Mitigation of harvest impacts will vary between species and harvesting methodologies. For example, establishment of large 'no take' reserves may assist in enabling recovery of depleted fish populations (Pauly et al. 1998), whereas sustainable forest management better relies on appropriate harvesting techniques to reduce biodiversity loss (Lindenmayer et al. 2006).

It is recommended that conservation managers engage with those conducting the harvest to inform them of the flesh-footed shearwater complication if harvest is allowed to become more frequent on Tîtī Island. Mitigating unnecessary harvest of flesh-footed shearwaters would be relatively simple if harvesters were to differentiate between species: flesh-footed shearwaters have a pale bill and feet compared with the darker features of their sooty counterparts (Marchant \& Higgins 1990). 
The results from Chapter Four suggest that the Motungārara and Titī Island populations are sensitive to changes in breeding success. In some cases, improving seabird breeding success has been possible through direct conservation action. For example, the eradication of feral cats (Felis catus) off Marion Island increased the breeding success of great-winged petrels (Pterodroma macroptera) from 0\% to 59.6-64.2\% (Cooper et al. 1995). On Tîtī Island, enhancing reproductive output would be difficult, but on Motungārara breeding success may be improved through ongoing weka removal. The predation pressure on sooty shearwater chicks by weka (Gallirallus australis) has been quantified for Taukihepa Island off Stewart Island (Harper 2006; Harper 2007). I too saw a large number of dead chicks outside their burrows (a phenomenon I witnessed on neither Titī nor Long Island) and while conducting fieldwork on Motungārara I saw a dead chick being eaten by a weka. There is a fine line between sustainable and unsustainable exploitation of small sooty shearwater populations. It is clear that Motungārara and Titī Islands are unable to sustain uncontrolled levels of harvest. It is therefore critical that illegal harvest is stopped on both Titī and Motungārara because the islands will probably not be able to sustain both traditional and illegal harvest. If unsolicited harvest continues, it will deny those desiring to undertake wānanga the ability to pass on or learn the mātauranga Māori of the islands and harvest.

\subsubsection{The importance of monitoring}

Determining the effects of harvest and the effectiveness of mitigation measures should be undertaken through comprehensive monitoring. The long life spans of seabirds mean detection of trends may require extended monitoring periods (Moller 2006). However, allowing resumed harvest may not only provide cultural benefits but could in fact result in subsequent benefits to conservation managers, such as the monitoring of population trends over time or alerting others to previously undetected declines (Moller et al. 2004; Gilchrist et al. 2005).

There is limited information on breeding success of sooty shearwater populations on both Titī and Motungārara Islands. It is important that additional information is 
gathered through a monitoring programme to increase the accuracy of the population viability analysis. Should the results of the analysis change then the decision and scale of harvest need to re-examined.

\subsubsection{Directions for ongoing research}

Effects of harvesting on population viability have been estimated, but factors such as

migration between populations and threats facing the populations have been excluded from analyses due to lack of information. Removal of chicks may only be offset by immigration from larger, more robust source populations (Peery et al. 2006).

Determining dispersal rates has proven difficult in other larger sooty shearwater populations (Newman et al. 2009b). Conducting a study into the level of population mixing between islands may prove logistically easier if centred in the Marlborough Sounds where the populations are smaller and sampling may be easier.

The output from VORTEX suggests that the Motungārara population has low, negative growth (Chapter Four). This output would need to be verified with long-term monitoring. Monitoring is needed to establish a better estimate of population size, to quantify chick production and would also assist in the monitoring of illicit access to the island. For example, I found what could have been tools used in harvest while conducting fieldwork on Motungārara and evidence of burrow damage likely caused by human presence. Annual surveys of the entire island would take, at most, two days to complete but in the case of time pressure, then quadrats would suffice.

\subsection{Re-establishing a connection through harvest}

Despite the reality of resumed harvest on Motungārara being unlikely, low-level harvest for the purpose of wānanga, at least on Titī, is potentially viable. Given the life history characteristics of the sooty shearwater, the islands may now be experiencing a lag time associated with overharvest in the past. Ongoing monitoring on Titī and the initiation of monitoring on Motungārara is recommended. The harvest and management of native fauna has immense spiritual and cultural significance to many 
Māori (Lyver et al. 2008a; 2008b; Moller et al. 2009c). Enabling the increased participation of Ngā Takiwā and Ngāti Kuia in the species' management on each island may prevent further poaching because it may be perceived to undermine the authority of the managing iwi (Coombes 2007) or the success of legitimate sustainable customary harvest (Kirikiri \& Nugent 1995). Active co-management of the resource by the iwi would be a positive step towards their reconnection to an important cultural species, regular monitoring and the potential recovery of the populations as well as the prevention of the loss of the mātauranga Māori regarding the islands and the harvest. 


\section{References}

Anderson A. (1997). Historical and archaeological aspects of muttonbirding in New Zealand. New Zealand Journal of Archaeology, 17, 35-55.

Armbruster P., Fernando P. \& Lande R. (1999). Time frames for population viability analysis of species with long generations: an example with Asian elephants. Animal Conservation, 2, 69-73.

Austin J.J. \& Parkin D.T. (1996). Low frequency of extra-pair paternity in two colonies of the socially monogamous short-tailed shearwater Puffinus tenuirostris. Molecular Ecology, 5, 145-150.

Baker B., Hedley G., Waugh S. \& Cunningham R. (2009). Data collection of demographic, distributional and trophic information on the flesh-footed shearwater to allow estimation of effects of fishing on population viability: 2008-09 field season. Latitude 42 Environmental Consultants, Kettering, Australia.

Baker G.B., Gales R., Hamilton S. \& Wilkinson V. (2002). Albatrosses and petrels in Australia: a review of their conservation and management. Emu, 102, 71-97.

Baker G.B. \& Wise B.S. (2005). The impact of pelagic longline fishing on the flesh-footed shearwater Puffinus carneipes in Eastern Australia. Biological Conservation, 126, 306-316.

Baldwin J.R. (1974). Sea bird fowling in Scotland and Faroe. Folk Life, 12, 60-103.

Baldwin J.R. (2009). Harvesting seabirds and their eggs on the Irish Sea Islands (Part 1: The Welsh Islands, Lundy and Scilly). Folk Life, 47, 76-96.

Barbraud C. \& Weimerskirch H. (2003). Climate and density shape population dynamics of a marine top predator. Proceedings of the Royal Society of London Series BBiological Sciences, 270, 2111-2116.

Bartmann R.M., White G.C. \& Carpenter L.H. (1992). Compensatory mortality in a Colorado mule deer population. Wildlife Monographs, 121, 5-39.

Beatty J. (1992). Sula: The Seabird-Hunters of Lewis. Michael Joseph, London.

Becker P.H., Ezard T.H.G., Ludwigs J.D., Sauer-Gurth H. \& Wink M. (2008). Population sex ratio shift from fledging to recruitment: consequences for demography in a philopatric seabird. Oikos, 117, 60-68.

Bell B.D. (1955a). Untitled. Lands \& Survey Department File, AAAC W3179 (Box 1) 46/5/11.

Bell B.D. (1969). Titi Island - Marlborough Sounds. Wildlife Service File, AANS W3832 (Box 13) 18/4/4. 
Bell L.C. (1955b). Muttonbirding - Motungarara Id., Q. C. Sound and Motu Ngarara Id., Pls. Sound. Lands \& Survey Department File, AAAC W3179 (Box 1) 46/5/11.

Berkes F. (2008). Sacred Ecology. Second Edition. Routledge, New York.

Berkes F. (2009). Indigenous ways of knowing and the study of environmental change. Journal of the Royal Society of New Zealand, 39, 151-156.

Berkes F., Colding J. \& Folke C. (2000). Rediscovery of traditional ecological knowledge as adaptive management. Ecological Applications, 10, 1251-1262.

Berkes F. \& Turner N.J. (2006). Knowledge, learning and the evolution of conservation practice for social-ecological system resilience. Human Ecology, 34, 479-494.

Berman M. \& Kofinas G. (2004). Hunting for models: grounded and rational choice approaches to analyzing climate effects on subsistence hunting in an Arctic community. Ecological Economics, 49, 31-46.

Bester A.J., Priddel D., Klomp N.I., Carlile N. \& O'Neill L. (2007). Reproductive success of the Providence petrel Pterodroma solandri on Lord Howe Island, Australia. Marine Ornithology, 35, 21-28.

Birdlife International (2008). Puffinus griseus. In: IUCN 2009. IUCN Red List of Threatened Species. Version 2009.2, [online] URL: http://www.iucnredlist.org.

Blanchard P., Hanuise N., Dano S. \& Weimerskirch H. (2007). Offspring sex ratio in relation to parental structural size and body condition in the long-lived wandering albatross (Diomedea exulans). Behavioral Ecology and Sociobiology, 61, 767-773.

Boyce M.S. (1992). Population viability analysis. Annual Review of Ecology and Systematics, 23, 481-506.

Bradley J.S., Gunn B.M., Skira I.J., Meathrel C.E. \& Wooller R.D. (1999). Age-dependent prospecting and recruitment to a breeding colony of short-tailed shearwaters Puffinus tenuirostris. Ibis, 141, 277-285.

Bradley J.S., Wooller R.D. \& Skira I.J. (2000). Intermittent breeding in the short-tailed shearwater Puffinus tenuirostris. Journal of Animal Ecology, 69, 639-650.

Bradley J.S., Wooller R.D., Skira I.J. \& Serventy D.L. (1989). Age-dependent survival of breeding short-tailed shearwaters Puffinus tenuirostris. Journal of Animal Ecology, 58, 175-188.

Bragg C., McKechnie S., Newman J., Fletcher D., Moller H. \& Scott D. (2009). Variation in abundance and harvest of sooty shearwaters (Puffinus griseus) by Rakiura Maori on Putauhinu Island, New Zealand. New Zealand Journal of Zoology, 36, 275-289.

Brook B.W. (2000). Pessimistic and optimistic bias in population viability analysis. Conservation Biology, 14, 564-566. 
Brook B.W., Burgman M.A., Akçakaya H.R., O'Grady J.J. \& Frankham R. (2002a). Critiques of PVA ask the wrong questions: throwing the heuristic baby out with the numerical bath water. Conservation Biology, 16, 262-263.

Brook B.W., Cannon J.R., Lacy R.C., Mirande C. \& Frankham R. (1999). Comparison of the population viability analysis packages GAPPS, INMAT, RAMAS and VORTEX for the whooping crane (Grus americana). Animal Conservation, 2, 23-31.

Brook B.W., Griffiths A.D. \& Puckey H.L. (2002b). Modelling strategies for the management of the critically endangered Carpentarian rock-rat (Zyzomys palatalis) of northern Australia. Journal of Environmental Management, 65, 355368.

Brook B.W. \& Kikkawa J. (1998). Examining threats faced by island birds: a population viability analysis on the Capricorn silvereye using longterm data. Journal of Applied Ecology, 35, 491-503.

Brook B.W., Lim L., Harden R. \& Frankham R. (1997). Does population viability analysis software predict the behaviour of real populations? A retrospective study on the Lord Howe Island woodhen Tricholimnas sylvestris (Sclater). Biological Conservation, 82, 119-128.

Brook B.W., O'Grady J.J., Chapman A.P., Burgman M.A., Akçakaya H.R. \& Frankham R. (2000). Predictive accuracy of population viability analysis in conservation biology. Nature, 404, 385-387.

Brook B.W. \& Whitehead P.J. (2005). Sustainable harvest regimes for magpie geese (Anseranas semipalmata) under spatial and temporal heterogeneity. Wildlife Research, 32, 459-464.

Brooke M.D.L. (2004). The food consumption of the world's seabirds. Proceedings of the Royal Society of London B-Biological Sciences, 271, S246-S248.

Brothers N.P. (1984). Breeding, distribution and status of burrow-nesting petrels at Macquarie Island. Australian Wildlife Research, 11, 113-131.

Burg T.M., Lomax J., Almond R., Brooke M.D. \& Amos W. (2003). Unravelling dispersal patterns in an expanding population of a highly mobile seabird, the northern fulmar (Fulmarus glacialis). Proceedings of the Royal Society of London Series BBiological Sciences, 270, 979-984.

Büßer C., Kahles A. \& Quillfeldt P. (2004). Breeding success and chick provisioning in Wilson's storm-petrels Oceanites oceanicus over seven years: frequent failures due to food shortage and entombment. Polar Biology, 27, 613-622.

Caputo F.P., Canestrelli D. \& Boitani L. (2005). Conserving the terecay (Podocnemis unifilis, Testudines: Pelomedusidae) through a community-based sustainable harvest of its eggs. Biological Conservation, 126, 84-92.

Caughley G. (1994). Directions in conservation biology. Journal of Animal Ecology, 63, 215-244. 
Charleton K., Bragg C., Knight B., Fletcher D., Moller H., Newman J. \& Scott D. (2009). Spatial variation in burrow entrance density of the sooty shearwater (Puffinus griseus). Notornis, 56, 1-10.

Chastel O., Weimerskirch H. \& Jouventin P. (1993). High annual variability in reproductive success and survival of an Antarctic seabird, the snow petrel Pagodroma nivea: a 27 year study. Oecologia, 94, 278-285.

Clucas R.J., Fletcher D.J. \& Moller H. (2008). Estimates of adult survival rate for three colonies of sooty shearwater (Puffinus griseus) in New Zealand. Emu, 108, 237250.

Colding J. \& Folke C. (2001). Social taboos: "invisible" systems of local resource management and biological conservation. Ecological Applications, 11, 584-600.

Coombes B. (2007). Postcolonial conservation and kiekie harvests at Morere New Zealand - abstracting Indigenous knowledge from Indigenous polities. Geographical Research, 45, 186-193.

Cooper J., Marais A.V.N., Bloomer J.P. \& Bester M.N. (1995). A success story: breeding of burrowing petrels (Procellariidae) before and after the eradication of feral cats Felis catus at subantarctic Marion Island. Marine Ornithology, 23, 33-37.

Coulson J.C. \& Coulson B.A. (2008). Measuring immigration and philopatry in seabirds; recruitment to black-legged kittiwake colonies. Ibis, 150, 288-299.

Coulson T., Mace G.M., Hudson E. \& Possingham H. (2001). The use and abuse of population viability analysis. Trends in Ecology \& Evolution, 16, 219-221.

Craig J., Anderson S., Clout M., Creese B., Mitchell N., Ogden J., Roberts M. \& Ussher G. (2000). Conservation issues in New Zealand. Annual Review of Ecology and Systematics, 31, 61-78.

Cruz J.B., Lalas C., Jillett J.B., Kitson J.C., Lyver P.O., Imber M., Newman J.E. \& Moller H. (2001). Prey spectrum of breeding sooty shearwaters (Puffinus griseus) in New Zealand. New Zealand Journal of Marine and Freshwater Research, 35, 817-829.

Cuthbert R. \& Davis L.S. (2002). Adult survival and productivity of Hutton's shearwaters. Ibis, 144, 423-432.

Cuthbert R.J. (2005). Breeding biology, chick growth and provisioning of great shearwaters (Puffinus gravis) at Gough Island, South Atlantic Ocean. Emu, 105, 305-310.

Davidson-Hunt A. \& Berkes F. (2003). Learning as you journey: Anishinaabe perception of social-ecological environments and adaptive learning. Conservation Ecology, 8, [online] URL: http://www.consecol.org/vol8/iss1/art5.

Dillingham P.W. \& Fletcher D. (2008). Estimating the ability of birds to sustain additional human-caused mortalities using a simple decision rule and allometric relationships. Biological Conservation, 141, 1783-1792. 
Dimond W.J. \& Armstrong D.P. (2007). Adaptive harvesting of source populations for translocation: a case study with New Zealand robins. Conservation Biology, 21, 114-124.

Douglas A.F. (1963). Muttonbirding: Motungarara Island, Queen Charlotte Sound. Lands \& Survey Department File, AAAC W3179 (Box 1) 46/5/11.

Dyer P.K. \& Hill G.J.E. (1991). A solution to the problem of determining the occupancy status of wedge-tailed shearwater Puffinus pacificus burrows. Emu, 91, 20-25.

Dyer P.K. \& Hill G.J.E. (1992). Active breeding burrows of the wedge-tailed shearwater in the Capricorn Group, Great Barrier Reef. Emu, 92, 147-151.

Dyer P.K., Hill G.J.E. \& Barnes A. (1995). Three decades of burrow estimates for wedgetailed shearwaters on the Capricorn Group. Emu, 95, 272-279.

Ellegren H. (1996). First gene on the avian W chromosome (CHD) provides a tag for universal sexing of non-ratite birds. Proceedings of the Royal Society of London Series B-Biological Sciences, 263, 1635-1641.

Elliott G.P., Eason D.K., Jansen P.W., Merton D.V., Harper G.A. \& Moorhouse R.J. (2006). Productivity of kakapo (Strigops habroptilus) on offshore island refuges. Notornis, 53, 138-142.

Feare C.J. (1976). The exploitation of sooty tern eggs in the Seychelles. Biological Conservation, 10, 169-181.

Feare C.J. (1978). The decline of booby (Sulidae) populations in the western Indian Ocean. Biological Conservation, 14, 295-305.

Feare C.J. (1984). Seabirds as a resource: use and management. In: Biogeography and Ecology of the Seychelles Islands (ed. Stoddard D.R.). Dr W. Junk Publishers, The Hague, pp. 593-606.

Gaston A.J. (1997). Mass and date at departure affect the survival of ancient murrelet Synthliboramphus antiquus chicks after leaving the colony. Ibis, 139, 673-678.

Gaze P. (2000). The response of a colony of sooty shearwater (Puffinus griseus) and flesh-footed shearwater ( $P$. carneipes) to the cessation of harvesting and the eradication of Norway rats (Rattus norvegicus). New Zealand Journal of Zoology, 27, 375-379.

Gaze P. \& Smith R. (2009). A harvesting wananga on Titi Island: maintaining connections by rekindling a wildlife harvest. Journal of the Royal Society of New Zealand, 39, 193-196.

Geary A. (2009). Titī Island burrow counts. Report for the Department of Conservation, Nelson.

Gilchrist G., Mallory M. \& Merkel F. (2005). Can local ecological knowledge contribute to wildlife management? Case studies of migratory birds. Ecology and Society, 10, [online] URL: http://www.ecologyandsociety.org/vol10/iss1/art20/. 
Grant A. (2001). DNA sexing of brown kiwi (Apteryx mantelli) from feather samples. DOC Science Internal Series 13, Department of Conservation, Wellington.

Greig D.M. (1949). Motungarara Island - Onehunga Bay, Queen Charlotte Sound. Lands \& Survey Department File, AAAC W3179 (Box 1) 46/5/11.

Grémillet D., Pichegru L., Kuntz G., Woakes A.G., Wilkinson S., Crawford R.J.M. \& Ryan P.G. (2008). A junk-food hypothesis for gannets feeding on fishery waste. Proceedings of the Royal Society B-Biological Sciences, 275, 1149-1156.

Griffiths R., Double M.C., Orr K. \& Dawson R.J.G. (1998). A DNA test to sex most birds. Molecular Ecology, 7, 1071-1075.

Haami B.J.T.M. (1994). The kiore rat in Aotearoa: a Maori perspective. In: Science of Pacific Island Peoples: Fauna, Flora, Food and Medicine (eds. Morrison J., Geraghty P. \& Crowl L.). Institute of Pacific Studies, University of the South Pacific, Suva.

Hamilton S. (1998). Determining burrow occupancy, fledging success and land-based threats to mainland and near-shore island sooty shearwater (Puffinus griseus) colonies. New Zealand Journal of Zoology, 25, 443-453.

Hamilton S. (2000). How precise and accurate are data obtained using an infra-red scope on burrow-nesting sooty shearwaters Puffinus griseus? Marine Ornithology, 28, 1-6.

Hamilton S. \& Moller H. (1995). Can PVA models using computer packages offer useful conservation advice? Sooty shearwaters Puffinus griseus in New Zealand as a case study. Biological Conservation, 73, 107-117.

Harper G. (2006). Weka (Gallirallus australis) depredation of sooty shearwater/titi (Puffinus griseus) chicks. Notornis, 53, 318-320.

Harper G.A. (2007). Detecting predation of a burrow-nesting seabird by two introduced predators, using stable isotopes, dietary analysis and experimental removals. Wildlife Research, 34, 443-453.

Harris M.P., Frederiksen M. \& Wanless S. (2007). Within- and between-year variation in the juvenile survival of common guillemots Uria aalge. Ibis, 149, 472-481.

Harris R.B., Wall W.A. \& Allendorf F. (2002). Genetic consequences of hunting: what do we know and what should we do? Wildlife Society Bulletin, 30, 634-643.

Haynes A.M. (1987). Human exploitation of seabirds in Jamaica. Biological Conservation, 41, 99-124.

Hilborn R., Walters C.J. \& Ludwig D. (1995). Sustainable exploitation of renewable resources. Annual Review of Ecology and Systematics, 26, 45-67.

Hunter C.M. \& Caswell H. (2005). Selective harvest of sooty shearwater chicks: effects on population dynamics and sustainability. Journal of Animal Ecology, 74, 589600. 
Hunter C.M., Moller H. \& Fletcher D. (2000a). Parameter uncertainty and elasticity analyses of a population model: setting research priorities for shearwaters. Ecological Modelling, 134, 299-323.

Hunter C.M., Moller H. \& Kitson J. (2000b). Muttonbirder selectivity of sooty shearwater (titi) chicks harvested in New Zealand. New Zealand Journal of Zoology, 27, 395-414.

Hutchings J.A. \& Myers R.A. (1994). What can be learned from the collapse of a renewable resource? Atlantic cod, Gadus morhua, of Newfoundland and Labrador. Canadian Journal of Fisheries and Aquatic Sciences, 51, 2126-2146.

Imber M.J., McFadden I., Bell E.A. \& Scofield R.P. (2003). Post-fledging migration, age of first return and recruitment, and results of inter-colony translocation of black petrels (Procellaria parkinsoni). Notornis, 50, 183-190.

IUCN (2001). IUCN Red List Categories and Criteria: Version 3.1. IUCN Species Survival Commission, Gland, Switzerland and Cambridge.

Jamieson I.G., Wallis G.P. \& Briskie J.V. (2006). Inbreeding and endangered species management: is New Zealand out of step with the rest of the world? Conservation Biology, 20, 38-47.

Jenouvrier S., Barbraud C. \& Weimerskirch H. (2003). Effects of climate variability on the temporal population dynamics of southern fulmars. Journal of Animal Ecology, 72, 576-587.

Jenouvrier S., Tavecchia G., Thibault J.C., Choquet R. \& Bretagnolle V. (2008). Recruitment processes in long-lived species with delayed maturity: estimating key demographic parameters. Oikos, 117, 620-628.

Jenouvrier S., Thibault J.C., Viallefont A., Vidals P., Ristow D., Mougin J.L., Brichetti P., Borg J.J. \& Bretagnolle V. (2009). Global climate patterns explain range-wide synchronicity in survival of a migratory seabird. Global Change Biology, 15, 268279.

Johannes R.E. (1978). Traditional marine conservation methods in Oceania and their demise. Annual Review of Ecology and Systematics, 9, 349-364.

Johannes R.E. (1982). Traditional conservation methods and protected marine areas in Oceania. Ambio, 11, 258-261.

Johannes R.E. (1998). The case for data-less marine resource management: examples from tropical nearshore finfisheries. Trends in Ecology \& Evolution, 13, 243-245.

Johannes R.E. (2003). Use and misuse of traditional ecological knowledge and management practices - Pacific Island examples. In: Values at Sea. Ethics for the Marine Environment (ed. Dallmeyer D.G.). University of Georgia Press, Athens, pp. 111-126. 
Johnson D.H. (1979). Estimating nest success, the Mayfield method and an alternative. Auk, 96, 651-661.

Jones C. (2002). A model for the conservation management of a 'secondary' prey: sooty shearwater (Puffinus griseus) colonies on mainland New Zealand as a case study. Biological Conservation, 108, 1-12.

Jones C., Bettany S., Moller H., Fletcher D., Lyver P. \& de Cruz J. (2003). Burrow occupancy and productivity at coastal sooty shearwater (Puffinus griseus) breeding colonies, South Island, New Zealand: can mark-recapture be used to estimate burrowscope accuracy? Wildlife Research, 30, 377-388.

Jones H.P., Tershy B.R., Zavaleta E.S., Croll D.A., Keitt B.S., Finkelstein M.E. \& Howald G.R. (2008). Severity of the effects of invasive rats on seabirds: a global review. Conservation Biology, 22, 16-26.

Keedwell R.J. (2003). Does fledging equal success? Post-fledging mortality in the blackfronted tern. Journal of Field Ornithology, 74, 217-221.

Kelly H.D. (1960). Muttonbirding in Pelorus Sound. Lands \& Survey Department File, AAAC W3179 (Box 1) 46/5/11.

Kirikiri R. \& Nugent G. (1995). Harvesting of New Zealand native birds by Maori. In: Conservation Through Sustainable Use of Wildlife (eds. Grigg G.C., Hale P.T. \& Lunney D.). University of Queensland, Centre for Conservation Biology, pp. 5459.

Kitson J.C. (2002). What limits the number of titi (Puffinus griseus) harvested by Rakiura Maori? Human Ecology, 30, 503-521.

Kitson J.C., Cruz J.B., Lalas C., Jillett J.B., Newman J. \& Lyver P.O. (2000). Interannual variations in the diet of breeding sooty shearwaters (Puffinus griseus). New Zealand Journal of Zoology, 27, 347-355.

Kitson J.C. \& Moller H. (2008). Looking after your ground: resource management practice by Rakiura Maori titi harvesters. Papers and Proceedings of the Royal Society of Tasmania, 142, 161-176.

Lack D. (1968). Ecological Adaptations for Breeding in Birds. Methuen, London.

Lacy R.C. (1993). VORTEX - A computer simulation model for population viability analysis. Wildlife Research, 20, 45-65.

Lande R. (1993). Risks of population extinction from demographic and environmental stochasticity and random catastrophes. American Naturalist, 142, 911-927.

Lande R., Engen S. \& Sæther B.-E. (1995). Optimal harvesting of fluctuating populations with a risk of extinction. American Naturalist, 145, 728-745.

Lande R., Sæther B.-E. \& Engen S. (1997). Threshold harvesting for sustainability of fluctuating resources. Ecology, 78, 1341-1350. 
Lane S.G. \& White G. (1983). Nesting of the sooty shearwater in Australia. Emu, 83, 117-118.

Lindenmayer D.B., Franklin J.F. \& Fischer J. (2006). General management principles and a checklist of strategies to guide forest biodiversity conservation. Biological Conservation, 131, 433-445.

Ludwig D., Hilborn R. \& Waters C. (1993). Uncertainty, resource exploitation, and conservation: lessons from history. Science, 260, 17+36.

Lyver P.O., Moller H. \& Thompson C. (1999). Changes in sooty shearwater Puffinus griseus chick production and harvest precede ENSO events. Marine Ecology Progress Series, 188, 237-248.

Lyver P.O.B. (2002). Use of traditional knowledge by Rakiura Maori to guide sooty shearwater harvests. Wildlife Society Bulletin, 30, 29-40.

Lyver P.O.B. (2005). Co-managing environmental research: lessons from two crosscultural research partnerships in New Zealand. Environmental Conservation, 32, 365-370.

Lyver P.O.B., Davis J., Ngamane L., Anderson A. \& Clarkin P. (2008a). Hauraki Maori matauranga for the conservation and harvest of titi, Pterodroma macroptera gouldi. Papers and Proceedings of the Royal Society of Tasmania, 142, 149-160.

Lyver P.O.B., Jones C.J. \& Doherty J. (2009). Flavor or forethought: Tuhoe traditional management strategies for the conservation of kereru (Hemiphaga novaeseelandiae novaeseelandiae) in New Zealand. Ecology and Society, 14, 40.

Lyver P.O.B., Taputu T.M., Kutia S.T. \& Tahi B. (2008b). Tūhoe Tuawhenua mātauranga of kererū (Hemiphaga novaseelandiae novaseelandiae) in Te Urewera. New Zealand Journal of Ecology, 32, 7-17.

MacLachlan R.J. (1968). Muttonbirding: Titi Island. Lands \& Survey Department File, AAAC W3179 (Box 1) 46/5/11.

Marchant S. \& Higgins P.J. (1990). Handbook of Australian, New Zealand and Antarctic Birds. Volume 1, Part A. Ratites to Petrels. Oxford University Press, Melbourne.

Marin A.M. (1984). Breeding record for the sooty shearwater (Puffinus griseus) from Chiloe Island, Chile. Auk, 101, 192.

Martin P.S. \& Steadman D.W. (1999). Prehistoric extinctions on islands and continents. In: Extinctions in Near Time. Causes, Contexts, and Consequences (ed. MacFee R.D.E.). Kluwer Academic/Plenum Publishers, New York, pp. 17-55.

Mauck R.A., Waite T.A. \& Parker P.G. (1995). Monogamy in Leach's storm-petrel: DNAfingerprinting evidence. Auk, 112, 473-482.

McCarthy M.A. (1996). Red kangaroo (Macropus rufus) dynamics: effects of rainfall, density dependence, harvesting and environmental stochasticity. Journal of Applied Ecology, 33, 45-53. 
McClellan R. (1996). Breeding Biology of the Flesh-footed Shearwater on Karewa Island. Unpublished MSc thesis. Victoria University of Wellington, Wellington, pp. 166.

McKechnie S., Fletcher D., Moller H., Scott D.S., Newman J. \& Bragg C. (2007). Estimating and correcting for bias in population assessments of sooty shearwaters. Journal of Wildlife Management, 71, 1325-1335.

Mead H.M. \& Grove N. (2001). Ngā Pēpeha a ngā Tıpuna. Victoria University Press, Wellington.

Meathrel C.E., Skira I.J., Bradley J.S. \& Wooller R.D. (1993). The influence of egg-size, mass and composition upon hatching success in the short-tailed shearwater Puffinus tenuirostris (Aves: Procellariiformes). Journal of Zoology, 230, 679-686.

Miller B. \& Mullette K.J. (1985). Rehabilitation of an endangered Australian bird: the Lord Howe Island woodhen Tricholimnas sylvestris (Sclater). Biological Conservation, 34, 55-95.

Miller H.W. \& Johnson D.H. (1978). Interpreting the results of nesting studies. Journal of Wildlife Management, 42, 471-476.

Milot E., Weimerskirch H., Duchesne P. \& Bernatchez L. (2007). Surviving with low genetic diversity: the case of albatrosses. Proceedings of the Royal Society $B$ Biological Sciences, 274, 779-787.

Miskelly C.M. (1987). The identity of the hakawai. Notornis, 34, 95-116.

Miskelly C.M. \& Taylor G.A. (2004). Establishment of a colony of common diving petrels (Pelecanoides urinatrix) by chick transfers and acoustic attraction. Emu, 104, 205-211.

Miskelly C.M., Taylor G.A., Gummer H. \& Williams R. (2009). Translocations of eight species of burrow-nesting seabirds (genera Pterodroma, Pelecanoides, Pachyptila and Puffinus: Family Procellariidae). Biological Conservation, 142, 1965-1980.

Mitchell H. \& Mitchell J. (2004). Te Tau Ihu o Te Waka: A History of Maori in Nelson and Marlborough. Volume 1. Te Tangata me te Whenua: The People and the Land. Huia, Wellington.

Moller H. (1996). Customary use of indigenous wildlife - towards a bicultural approach to conserving New Zealand's biodiversity. In: Biodiversity: Papers from a Seminar Series on Biodiversity, hosted by Science and Research Division, Department of Conservation, Wellington, 14 June - 26 July 1994 (eds. McFadgen B. \& Simpson P.), pp. 89-125.

Moller H. (2006). Are current harvests of seabirds sustainable? Acta Zoologica Sinica, $52,649-652$.

Moller H., Berkes F., Lyver P.O.B. \& Kislalioglu M. (2004). Combining science and traditional ecological knowledge: monitoring populations for co-management. 
Ecology and Society, 9, [online] URL:

http://www.ecologyandsociety.org/vol9/iss3/art2.

Moller H., Fletcher D., Johnson P.N., Bell B.D., Flack D., Bragg C., Scott D., Newman J., McKechnie S. \& Lyver P.O.B. (2009a). Changes in sooty shearwater (Puffinus griseus) abundance and harvesting on the Rakiura Titī Islands. New Zealand Journal of Zoology, 36, 325-341.

Moller H., Kitson J.C. \& Downs T.M. (2009b). Knowing by doing: learning for sustainable muttonbird harvesting. New Zealand Journal of Zoology, 36, 243-258.

Moller H., Lyver P.O.B., Bragg C., Newman J., Clucas R., Fletcher D., Kitson J.C., McKechnie S., Scott D. \& Rakiura Titi Islands Administering Body (2009c). Guidelines for cross-cultural Participatory Action Research partnerships: a case study of a customary seabird harvest in New Zealand. New Zealand Journal of Zoology, 36, 211-241.

Mougin J.L., Jouanin C. \& Roux F. (1997). Intermittent breeding in Cory's Shearwater Calonectris diomedea of Selvagem Grande, North Atlantic. Ibis, 139, 40-44.

Mougin J.L., Jouanin C., Roux F. \& Zino F. (2000). Fledging weight and juvenile survival of Cory's shearwater Calonectris diomedea on Selvagem Grande. Ringing \& Migration, 20, 107-110.

Nabhan G.P. (2000). Interspecific relationships affecting endangered species recognized by O'odham and Comcáac cultures. Ecological Applications, 10, 1288-1295.

Newman J. (2009). Red alert! Red-billed gull warning signs. Titī Times, 21, 18-19.

Newman J., Fletcher D., Moller H., Bragg C., Scott D. \& McKechnie S. (2009a). Estimates of productivity and detection probabilities of breeding attempts in the sooty shearwater (Puffinus griseus), a burrow-nesting petrel. Wildlife Research, 36, 159-168.

Newman J., Scott D., Bragg C., McKechnie S., Moller H. \& Fletcher D. (2009b). Estimating regional population size and annual harvest intensity of the sooty shearwater in New Zealand. New Zealand Journal of Zoology, 36, 307-323.

Newman J., Scott D., Fletcher D.J., Moller H. \& McKechnie S. (2008). A population and harvest intensity estimate for sooty shearwater, Puffinus griseus, on Taukihepa (Big South Cape), New Zealand. Papers and Proceedings of the Royal Society of Tasmania, 142, 177-184.

Newsome A.E. (1980). The eco-mythology of the red kangaroo in Central Australia. Mankind, 12, 327-333.

O'Grady J.J., Reed D.H., Brook B.W. \& Frankham R. (2008). Extinction risk scales better to generations than to years. Animal Conservation, 11, 442-451.

Odum E.P. \& Kuenzler E.J. (1955). Measurement of territory and home range size in birds. Auk, 72, 128-137. 
Oka N. (1994). Sustainable exploitation of streaked shearwaters Calonectris leucomelas on Mikura Island, off the Izu Peninsula, Japan. Journal of the Yamashina Institute for Ornithology, 26, 99-108.

Ollason J.C. \& Dunnet G.M. (1983). Modelling annual changes in numbers of breeding fulmars, Fulmarus glacialis, at a colony in Orkney. Journal of Animal Ecology, 52, 185-197.

Oro D., Aguilar J.S., Igual J.M. \& Louzao M. (2004). Modelling demography and extinction risk in the endangered Balearic shearwater. Biological Conservation, $116,93-102$.

Parlee B., Manseau M. \& Łutsël K'É Dene First Nation (2005). Using traditional knowledge to adapt to ecological change: Denésołiné monitoring of caribou movements. Arctic, 58, 26-37.

Pauly D., Christensen V., Dalsgaard J., Froese R. \& Torres Jr. F. (1998). Fishing down marine food webs. Science, 279, 860-863.

Peery M.Z., Becker B.H. \& Beissinger S.R. (2006). Combining demographic and countbased approaches to identify source-sink dynamics of a threatened seabird. Ecological Applications, 16, 1516-1528.

Perry G. \& Pianka E.R. (1997). Animal foraging: past, present and future. Trends in Ecology \& Evolution, 12, 360-364.

Powell C.D.L., Wooller R.D. \& Bradley J.S. (2007). Breeding biology of the flesh-footed shearwater (Puffinus carneipes) on Woody Island, Western Australia. Emu, 107, 275-283.

Priddel D., Carlile N., Fullagar P., Hutton I. \& O'Neill L. (2006). Decline in the distribution and abundance of flesh-footed shearwaters (Puffinus carneipes) on Lord Howe Island, Australia. Biological Conservation, 128, 412-424.

Ramstad K.M., Nelson N.J., Paine G., Beech D., Paul A., Paul P., Allendorf F.W. \& Daugherty C.H. (2007). Species and cultural conservation in New Zealand: Maori traditional ecological knowledge of Tuatara. Conservation Biology, 21, 455-464.

Ramstad K.M., Paine G., Dunning D.L., Geary A.F., Keall S.N. \& Nelson N.J. (2009). Effective partnerships between universities and indigenous communities: a case study in tuatara conservation in Aotearoa. Journal of the Royal Society of New Zealand, 39, 229-231.

Reed J.M., Elphick C.S. \& Oring L.W. (1998). Life-history and viability analysis of the endangered Hawaiian stilt. Biological Conservation, 84, 35-45.

Reyes-Arriagada R., Campos-Ellwanger P., Schlatter R.P. \& Baduini C. (2007). Sooty shearwater (Puffinus griseus) on Guafo Island: the largest seabird colony in the world? Biodiversity and Conservation, 16, 913-930. 
Richdale L.E. (1954). Duration of parental attentiveness in the sooty shearwater. Ibis, 96, 586-600.

Richdale L.E. (1963). Biology of the sooty shearwater Puffinus griseus. Proceedings of the Zoological Society of London, 141, 1-117.

Roberts M., Norman W., Minhinnick N., Wihongi D. \& Kirkwood C. (1995). Kaitiakitanga: Maori perspectives on conservation. Pacific Conservation Biology, 2, 7-20.

Robertson G., McNeill M., Smith N., Wienecke B., Candy S. \& Olivier F. (2006). Fast sinking (integrated weight) longlines reduce mortality of white-chinned petrels (Procellaria aequinoctialis) and sooty shearwaters (Puffinus griseus) in demersal longline fisheries. Biological Conservation, 132, 458-471.

Rolland V., Nevoux M., Barbraud C. \& Weimerskirch H. (2009). Respective impact of climate and fisheries on the growth of an albatross population. Ecological Applications, 19, 1336-1346.

Rosser A.M. \& Mainka S.A. (2002). Overexploitation and species extinctions. Conservation Biology, 16, 584-586.

Sæther B.-E., Engen S., Møller A.P., Visser M.E., Matthysen E., Fiedler W., Lambrechts M.M., Becker P.H., Brommer J.E., Dickinson J., Du Feu C., Gehlbach F.R., Merilä J., Rendell W., Robertson R.J., Thomson D. \& Török J. (2005a). Time to extinction of bird populations. Ecology, 86, 693-700.

Sæther B.-E., Lande R., Engen S., Weimerskirch H., Lillegård M., Altwegg R., Becker P.H., Bregnballe T., Brommer J.E., McCleery R.H., Merilä J., Nyholm E., Rendell W., Robertson R.R., Tryjanowski P. \& Visser M.E. (2005b). Generation time and temporal scaling of bird population dynamics. Nature, 436, 99-102.

Sagar P.M. \& Horning D.S., Jr. (1998). Mass-related survival of fledgling sooty shearwaters Puffinus griseus at The Snares, New Zealand. Ibis, 140, 329-331.

Scofield R.P. \& Christie D. (2002). Beach patrol records indicate a substantial decline in sooty shearwater (Puffinus griseus) numbers. Notornis, 49, 158-165.

Scofield R.P., Fletcher D.J. \& Robertson C.J.R. (2001). Titi (sooty shearwaters) on Whero Island: analysis of historic data using modern techniques. Journal of Agricultural Biological and Environmental Statistics, 6, 268-280.

Scott D., Scofield P., Hunter C. \& Fletcher D. (2008). Decline of sooty shearwaters, Puffinus griseus, on the Snares, New Zealand. Papers and Proceedings of the Royal Society of Tasmania, 142, 185-196.

Serventy D.L. (1967). Aspects of the population ecology of the short-tailed shearwater Puffinus tenuirostris. Proceedings of the International Ornithological Congress, 14, 338-343. 
Serventy D.L. \& Curry P.J. (1984). Observations on colony size, breeding success, recruitment and inter-colony dispersal in a Tasmanian colony of short-tailed shearwaters Puffinus tenuirostris over a 30-year period. Emu, 84, 71-79.

Shaffer M.L. (1981). Minimum population sizes for species conservation. Bioscience, 31, 131-134.

Shaffer S.A., Tremblay Y., Weimerskirch H., Scott D., Thompson D.R., Sagar P.M., Moller H., Taylor G.A., Foley D.G., Block B.A. \& Costa D.P. (2006). Migratory shearwaters integrate oceanic resources across the Pacific Ocean in an endless summer. Proceedings of the National Academy of Sciences of the United States of America, 103, 12799-12802.

Shaffer S.A., Weimerskirch H., Scott D., Pinaud D., Thompson D.R., Sagar P.M., Moller H., Taylor G.A., Foley D.G., Tremblay Y. \& Costa D.P. (2009). Spatiotemporal habitat use by breeding sooty shearwaters Puffinus griseus. Marine Ecology Progress Series, 391, 209-220.

Skira I.J. \& Wapstra J.E. (1980). Occupation of burrows as a means of estimating the harvest of short-tailed shearwaters in Tasmania. Emu, 80, 233-238.

Skira I.J., Wapstra J.E., Towney G.N. \& Naarding J.A. (1986). Conservation of the shorttailed shearwater Puffinus tenuirostris in Tasmania, Australia. Biological Conservation, 37, 225-236.

Slooten E., Fletcher D. \& Taylor B.L. (2000). Accounting for uncertainty in risk assessment: case study of Hector's dolphin mortality due to gillnet entanglement. Conservation Biology, 14, 1264-1270.

Steadman D.W. (1995). Prehistoric extinctions of Pacific island birds: biodiversity meets zooarchaeology. Science, 267, 1123-1131.

Stearns S.C. (1976). Life-history tactics: a review of the ideas. Quarterly Review of Biology, 51, 3-47.

Taiepa T., Lyver P., Horsley P., Davis J., Bragg M. \& Moller H. (1997). Co-management of New Zealand's conservation estate by Maori and Pakeha: a review.

Environmental Conservation, 24, 236-250.

Tau T. (2001). The death of knowledge. New Zealand Journal of History, 35, 131-152.

Telfer W.R. \& Garde M.J. (2006). Indigenous knowledge of rock kangaroo ecology in western Arnhem Land, Australia. Human Ecology, 34, 379-406.

Towns D.R., Parrish G.R., Tyrrell C.L., Ussher G.T., Cree A., Newman D.G., Whitaker A.H. \& Westbrooke I. (2007). Responses of tuatara (Sphenodon punctatus) to removal of introduced Pacific rats from islands. Conservation Biology, 21, 10211031. 
Tuck G.N., Polacheck T., Croxall J.P. \& Weimerskirch H. (2001). Modelling the impact of fishery by-catches on albatross populations. Journal of Applied Ecology, 38, 1182-1196.

Tufto J., Sæther B.-E., Engen S., Swenson J.E. \& Sandegren F. (1999). Harvesting strategies for conserving minimum viable populations based on World Conservation Union criteria: brown bears in Norway. Proceedings of the Royal Society of London Series B-Biological Sciences, 266, 961-967.

Turner N.J., Ignace M.B. \& Ignace R. (2000). Traditional ecological knowledge and wisdom of aboriginal peoples in British Columbia. Ecological Applications, 10, 1275-1287.

Uhlmann S., Fletcher D. \& Moller H. (2005). Estimating incidental takes of shearwaters in driftnet fisheries: lessons for the conservation of seabirds. Biological Conservation, 123, 151-163.

Vargas F.H., Lacy R.C., Johnson P.J., Steinfurth A., Crawford R.J.M., Boersma P.D. \& Macdonald D.W. (2007). Modelling the effect of El Niño on the persistence of small populations: the Galápagos penguin as a case study. Biological Conservation, 137, 138-148.

Veit R.R., McGowan J.A., Ainley D.G., Wahls T.R. \& Pyle P. (1997). Apex marine predator declines ninety percent in association with changing oceanic climate. Global Change Biology, 3, 23-28.

Veit R.R., Pyle P. \& McGowan J.A. (1996). Ocean warming and long-term change in pelagic bird abundance within the California current system. Marine EcologyProgress Series, 139, 11-18.

Wanless R.M., Angel A., Cuthbert R.J., Hilton G.M. \& Ryan P.G. (2007). Can predation by invasive mice drive seabird extinctions? Biology Letters, 3, 241-244.

Wanless R.M., Ryan P.G., Altwegg R., Angel A., Cooper J., Cuthbert R. \& Hilton G.M. (2009). From both sides: dire demographic consequences of carnivorous mice and longlining for the critically endangered Tristan albatrosses on Gough Island. Biological Conservation, 142, 1710-1718.

Wanless S., Harris M.P., Redman P. \& Speakman J.R. (2005). Low energy values of fish as a probable cause of a major seabird breeding failure in the North Sea. Marine Ecology-Progress Series, 294, 1-8.

Warham J. (1990). The Petrels. Their Ecology and Breeding Systems. Academic Press, London.

Warham J. (1996). The Behaviour, Population Biology and Physiology of the Petrels. Academic Press, London.

Warham J. \& Wilson G.J. (1982). The size of the sooty shearwater Puffinus griseus population at the Snares Islands New Zealand. Notornis, 29, 23-30. 
Warham J., Wilson G.J. \& Keeley B.R. (1982). The annual cycle of the sooty shearwater Puffinus griseus at the Snares Islands New Zealand. Notornis, 29, 269-292.

Webb D.N.R. (1959). Muttonbirds in Pelorus Sound. Lands \& Survey Department File, AAAC W3179 (Box 1) 46/5/11.

Wehi P.M. (2009). Indigenous ancestral sayings contribute to modern conservation partnerships: examples using Phormium tenax. Ecological Applications, 19, 267275.

Weimerskirch H. (1998). How can a pelagic seabird provision its chick when relying on a distant food resource? Cyclic attendance at the colony, foraging decision and body condition in sooty shearwaters. Journal of Animal Ecology, 67, 99-109.

Weimerskirch H., Brothers N. \& Jouventin P. (1997). Population dynamics of wandering albatross Diomedea exulans and Amsterdam albatross $D$. amsterdamensis in the Indian Ocean and their relationships with long-line fisheries: conservation implications. Biological Conservation, 79, 257-270.

Weimerskirch H., Lallemand J. \& Martin J. (2005). Population sex ratio variation in a monogamous long-lived bird, the wandering albatross. Journal of Animal Ecology, 74, 285-291.

Weimerskirch H., Zimmermann L. \& Prince P.A. (2001). Influence of environmental variability on breeding effort in a long-lived seabird, the yellow-nosed albatross. Behavioral Ecology, 12, 22-30.

Wilson E. (1979). Titī heritage: The story of the Muttonbird Islands. Craig Printing, Invercargill.

Wooller R.D., Bradley J.S., Skira I.J. \& Serventy D.L. (1990). Reproductive success of short-tailed shearwaters Puffinus tenuirostris in relation to their age and breeding experience. Journal of Animal Ecology, 59, 161-170. 